Portland State University

PDXScholar

Spring 7-18-2018

\title{
Stance-taking: JFL Learners and Benefactive Verbs
}

Kumiko Takizawa

Portland State University

Follow this and additional works at: https://pdxscholar.library.pdx.edu/open_access_etds

Part of the Japanese Studies Commons, and the Linguistics Commons Let us know how access to this document benefits you.

\section{Recommended Citation}

Takizawa, Kumiko, "Stance-taking: JFL Learners and Benefactive Verbs" (2018). Dissertations and Theses. Paper 4481.

https://doi.org/10.15760/etd.6365

This Thesis is brought to you for free and open access. It has been accepted for inclusion in Dissertations and Theses by an authorized administrator of PDXScholar. Please contact us if we can make this document more accessible: pdxscholar@pdx.edu. 
Stance-taking: JFL Learners and Benefactive Verbs

by

Kumiko Takizawa

A thesis submitted in partial fulfillment of the requirements for the degree of

\author{
Master of Arts \\ in \\ Japanese
}

Thesis Committee:

Patricia J. Wetzel, Chair

Jon Holt

Suwako Watanabe

Portland State University

2018 
(C) 2018 Kumiko Takizawa 


\begin{abstract}
This study explores how JFL learners take a benefactive stance in Japanese. As Jaffe (2009) observes, stance-taking "plays a complex role with respect to the naturalization of social and linguistic ideologies and the social structures they legitimate." The way in which language is used to take a stance always concerns the social context in which a speaker finds her/himself. In Japanese, benefactive verbs (kureru, ageru, morau and their honorific and humble equivalents) are indispensable stance indicators for showing gratitude or indebtedness. Such expressions do not really exist in English and their grammar is complex. It is assumed that JFL learners will struggle with taking a benefactive stance using those expressions.

In order to analyze JFL learners' stance-taking, data were collected from narrative interviews with ten JFL learners who are currently in 300- and 400-level university courses. In order to explore how learners attempt to show stance-reflecting benefaction, they were asked questions that aimed to elicit a speaker's feelings of gratitude. Some examples of such questions are, "Who do you appreciate the most in your life?" or "Who is the most generous person you know?"
\end{abstract}

The data show that (1) learners do use (or attempt to use) benefactive verbs to 
indicate stance, (2) they also fail to use benefactive verbs in contexts where they are called for, and (3) they misuse benefactive verbs, e.g., using ageru instead of kureru.

Furthermore, it revealed that learners tend to show stance using adjectives, adverbs, or ritual expressions that show appreciation but they fail to utilize benefactive. This failure to project a benefactive stance can lead to miscommunication and/or misunderstanding between learners and Japanese speakers. I offer possible ways to promote learners' awareness of the benefaction in Japanese culture. 


\section{ACKNOWLEDGEMENTS}

First and foremost, I would like to express my sincerest gratitude to my thesis

advisor, Dr. Patricia Wetzel, for her continuous support, patience, inspiration, and

encouragement. It has been my honor to be her last M.A. student. Without her guidance, I

could not have completed this project. I truly cannot thank her enough.

I would also like to thank the other members of my thesis committee, Dr. Jon

Holt and Dr. Suwako Watanabe, for giving me great advice on my research and their

support throughout my years at PSU.

My sincere thanks also go to the other faculty members, Dr. Karen Curtin and

Dr. Lawrence Kominz for offering their support and inspiration. They always inspired me

to become a scholar in this field.

I am also indebted to my colleagues who shared friendships and encouragement

during my years at PSU. I have been blessed to work with this amazing team, a list that

includes Mina Asai, Benjamin Burton, Peter Fodor, Teppei Fukuda, Nobuko Horikawa,

Narumi Iwasaki, Natsuko Llewellyn, Tomomi Matsumura, Paolo Menuez, Jitsuya

Nishiyama, Nao Okumura, and Gabriel Rodriguez. 
I also would like to thank my parents, Toshio Takizawa and Keiko Takizawa, for

their endless love and support. Last but not least, my heartfelt appreciation goes to Kevin

Faris and his family for their faithful support and encouragement in the past three years.

I have been extremely fortunate to be supported and inspired by such wonderful

people while working on my thesis. To all of you, I would like to give my sincerest

appreciation. Thank you. 


\section{TABLE OF CONTENTS}

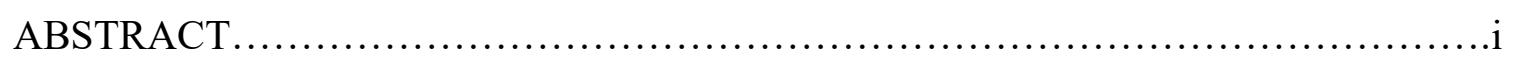

ACKNOWLEDGEMENTS ..................................................

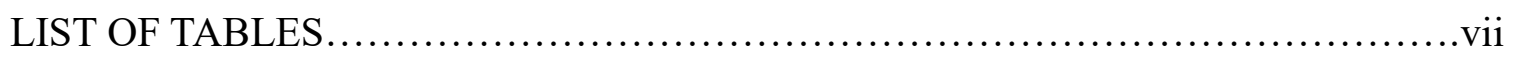

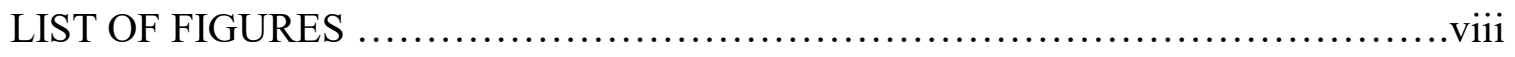

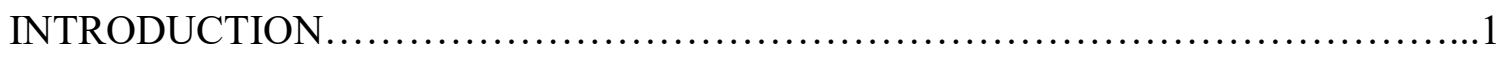

CHAPTER 1: STANCE: LITERATURE REVIEW,

DEFINITION, AND CATEGORIES .........................................

1.1. Stance - Literature review

1.2. Stance and modality

1.3. Definition and categories of stance

1.3.1. Evaluation and affect

1.3.2. Epistemic stance

1.3.3. Interpersonal stance

1.3.4. How the varieties of stance overlap

1.4. Stance indicators in Japanese

1.4.1. Sentence-final particles

1.4.2. Style

1.4.3. Uchi-Soto indicators

1.5. Benefactive expressions: Giving and receiving in Japanese

CHAPTER 2: RESEARCH METHODS ......................................23

2.1. Research design

2.2. Participants 
2.3. Data collection procedure

2.4. Analytical procedure for the interview

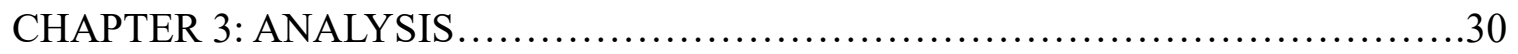

3.1. Do learners use benefactive verbs?

3.2. Do learners fail to use benefactive verbs?

3.3. Do learners misuse benefactive verbs?

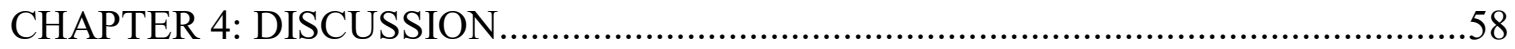

4.1. Are there any generalizations to be made about the usage of these stance indicators?

4.2. Learners' view of benefactive verbs

4.3. Pedagogical implication

4.3.1. Can we operationalize the notion of stance for the classroom?

4.3.2. Keywords

CHAPTER 5: CONCLUSION.

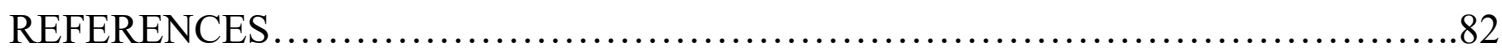

\section{APPENDICES}

A. INFORMED CONSENT FORM.................................... 86

B. INTERVIEW QUESTIONS ...................................... 88

C. POST-INTERVIEW QUESTIONS.....................................89

D. INSTRUCTION FOR THE CHECKER................................ 90

E. TRANSCRIPTION CONVERSATIONS ..............................91

F. TRANSCRIPTIONS OF THE INTERVIWS ............................ 92 


\section{LIST OF TABLES}

\section{TABLE A}

Participants' information.................................................... 25

\section{TABLE B}

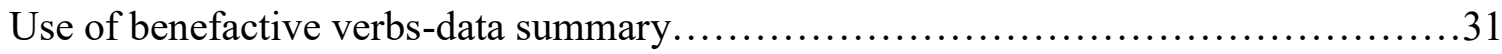

\section{TABLE C}

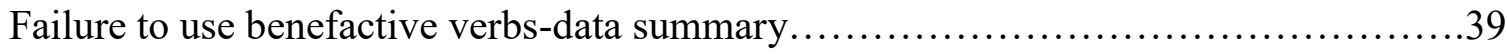

\section{TABLE D}

Misuse of benefactive verbs-data summary. 


\section{LIST OF FIGURES}

\section{FIGURE 1}

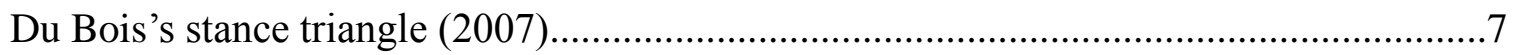




\section{INTRODUCTION}

The goal of this thesis is to account for how American learners of Japanese take

a stance when they speak in Japanese. As Jaffe (2009) observes, stance-taking "plays a

complex role with respect to the naturalization of social and linguistic ideologies and the

social structures they legitimate." The way in which language is used to take a stance

always concerns the social context in which a speaker finds her/himself. Furthermore,

taking a certain stance does not involve only the speaker's point of view but also that of

participants in the conversation as well as people who the speaker is referring to. For

learners of a foreign-language, taking a stance should be in line with what native speakers

expect - that is, should be culturally coherent. If this does not happen, the speaker fails to

project the stance that s/he intends to, which in turn can cause miscommunication or

misunderstanding among the participants. Therefore, it is important for foreign language

learners to understand how people take a stance in the target culture and also to be able to

utilize grammatical devices to project their stance successfully. It is assumed here that

learners cannot take the stance they wish to take or unknowingly fail to take a stance due

to numerous reasons such as lack of knowledge regarding Japanese social structure or

lack of language competence. In this thesis, I focus on how American learners of 
Japanese take an interpersonal stance by analyzing their use of benefactive verbs. My questions are: Do they use benefactive verbs? Do they fail to use or misuse benefactive verbs? Are there any generalizations to be made about learners' use of stance indicators? In order to examine learners' use of interpersonal stance indicators, this study conducts narrative interviews with learners and examines the transcripts of their interviews. 


\section{CHAPTER 1:}

\section{STANCE: LITERATURE REVIEW, DEFINITION, AND CATEGORIES}

\subsection{Stance - Literature review}

Stance is often used colloquially to indicate a way of standing, posture and intellectual or emotional attitude. According to the Cambridge dictionary (2008), stance stands for "an opinion about something, especially one that is publicly expressed." It is important to note, first of all, that there is no unified definition of stance in the social sciences. The aim of this literature review is to explore how the theoretical notion of stance has been discussed in sociolinguistics and related studies in order to provide a backdrop for what follows.

In early studies of stance, it is discussed in association with other concepts such as feeling, attitude, and evaluation. Biber and Finegan (1989) define stance as "the lexical and grammatical expression of attitudes, feelings, judgments, or commitment concerning the propositional content of a message" (p. 93). In their study of English, they divide stance markers into twelve categories based on semantic and grammatical criteria. Those are: (1) affect markers (adverbs, verbs, and adjectives such as happily, I ENJOY..., It is AMAZING that...); (2) certainty adverbs (surely, indeed, without doubt); (3) certainty 
verbs (I CONCLUDE, This DEMONSTRATES that... ); (4) certainty adjectives (impossible, obvious, true); (5) doubt adverbs (allegedly, perhaps, supposedly); (6) doubt verbs (I ASUUME..., This INDICATES that...); (7) doubt adjectives (alleged, dubious, uncertain ); (8) hedges (at about, maybe, sort of); (9) emphatics (for sure, really, so + ADJ); (10) possibility modals (may, might, could); (11) necessity modals (ought, should); and (12) predictive modals (will, shall). Biber and Finegan analyze these stance markers and conclude that they are used to indicate stances which include affect, certainty, hedges, emphasis, doubt, possibility, prediction, and necessity. However, they do not claim universality in their conclusion, which leaves us with the question of whether speakers of other languages take a stance in the same way that English speakers do. In contrast, other research subsumes stance under the rubric of evaluation. Thompson and Hunston (2000) explore texts and analyze how a writer indicates her/his evaluation of the message. They define evaluation as follows: "Evaluation is the broad cover term for the expression of the speaker or writer's attitude or stance towards, viewpoint on, or feelings about the entities or propositions that he or she is talking about" (p. 5). According to Thompson and Hunston, evaluation is closely tied to a speaker's judgment of the good or bad, desirable or undesirable, and certain or uncertain. They 
argue that stance and evaluation both express a speaker/writer's point of view and judgment. Thus, stance is sometimes associated with evaluation and evaluation is sometimes associated with stance. This is because both evaluation and stance are clearly related to a speaker's or a writer's judgments and feelings towards what s/he is talking about. In this thesis, I will use stance as the more general term and categorize evaluation as a subordinate category of stance.

In more recent work, the notion of stance is expanded. Kiesling (2009) suggests that stance concerns epistemic modality and interpersonal relations. He defines stance as "a person's expression of their relationship to their talk (their epistemic stance - e.g., How certain they are about their assertions), and a person's expression of their relationship to their interlocutors (their interpersonal stance -e.g., friendly or dominating.)" (p. 172). Kiesling's notion of stance includes epistemic stance, which is usually taken to be one's certainty towards the message as well as interpersonal attitude towards the interlocutor. Kiesling argues that epistemic stance and interpersonal stance are often related. He points out that someone who is patronizing (interpersonal stance) tends to be clear and certain (epistemic stance). It is important to note that epistemic stance is identical to the notion of epistemic modality: "indication by the speaker of his 
(lack of) commitment to the truth of the proposition being expressed" (Palmer 1986: 51).

In this thesis, I categorize epistemic modality as one of the subordinate categories of stance.

In yet a third investigation into stance, Du Bois (2007) defines it as "a public act by a social actor, achieved dialogically through overt communicative means (language, gesture, and other symbolic forms), through which social actors simultaneously evaluate objects, position subjects (themselves and others), and align with other subjects, with respect to any salient dimension of the sociocultural field" (p. 163). Du Bois considers the possible types of stance and proposes a stance triangle model. He argues that when a subject takes a stance, s/he positions her/himself by evaluating an "object (what they are talking about)" and align with other subjects. For example, when a person (subject 1) says "I don't like the movie," s/he is making an evaluation of the movie. To respond to this utterance, another person (subject 2) might say "I don't like it either." With this utterance, subject 2 is not only evaluating the movie, but also aligning with subject 1 by agreeing with her/him. What is remarkable about Du Bois's view of stance is that he wants to incorporate not only evaluation but also how a speaker positions her/himself vis a vis others - how a speaker aligns with other participants in the interaction. Although $\mathrm{Du}$ 
Bois suggests that stance can be shown through gesture and other symbolic forms, I focus only on the linguistic realization of stance in this thesis.

\section{Figure 1. Du Bois's stance triangle (2007)}

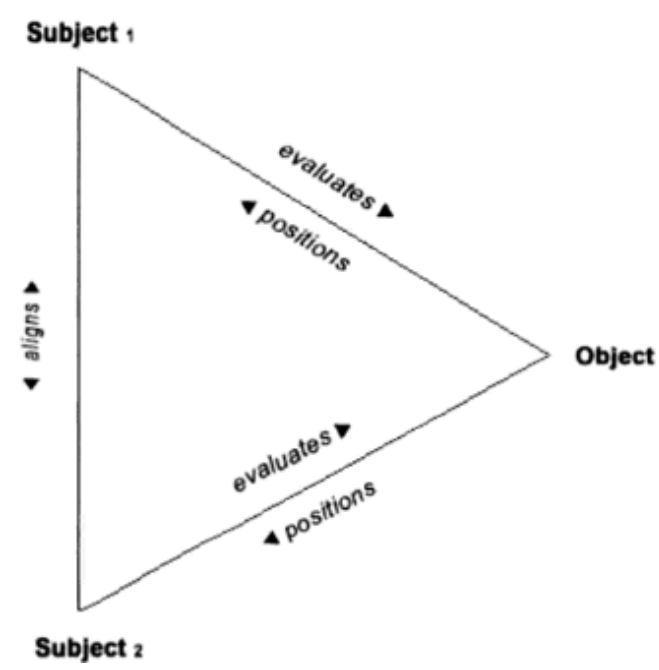

Stance is also discussed in association with "stance-taking." In "Stance in

Discourse" (2007), Englebretson reviews past studies, arguing that stance can be subdivided into evaluation, affect, and epistemicity. Epistemicity refers to a speaker's commitment towards the propositional content and would again appear to have much in common with the notion of epistemic modality. Englebreston emphasizes that stance is something in which people "engage in": "Stances are things people actively engage in (i.e., stance-taking is a gerund, based on an object-incorporation of stance and the active 
verb take)" (p. 3). He emphasizes that stance-taking happens in discourse and we can observe stance-taking within situated contexts. Du Bois (2007) (above) also views stance as an act people take: "stance is not something you have, but something you do something you take" (p.171). White (2003) observes mass-communicative texts and proposes a framework for analyzing stance-taking based on lexico-grammatical forms, structures, and wording. White explores stance in terms of stance-taking and defines it as an activity that provides a speaker/writer with tools to position her/himself with regard to other social subjects. As the fact that we "take a stance" shows, stance-taking is an act a person engages in and performs. In other words, stance is closely connected with social aspects of human behavior. We can observe stance-taking in any kind of social activity because it is a social behavior by which a speaker/writer positions her/himself within the social context through evaluating what s/he is talking about, topic, or her/his message content itself.

\subsection{Stance and modality}

As is clear from the work of Englebretson (2007) and Kiesling (2009), stance clearly has much in common with modality. However, it is clear that their function is different when we consider that we can say "s/he takes a 'stance'," but we cannot say 
"s/he takes a 'modality'." This example shows that what they achieve is different. When a speaker takes a stance, s/he attempts to project their evaluation or attitude about entities into the context. On the other hand, modality has to do with the proposition contained in the utterance, apart from context. Furthermore, Thompson and Hunston (2000) point out, "modality is usually discussed under the heading of grammar, centered around the functionally dedicated class of modal verbs" (p. 20). Based on the fact that modality is more grammaticalized and can be identified with modal verbs or adverbs, modality is one of the formal (in the grammatical sense) means of taking a stance. One might use modality to indicate a stance, but no one would use a stance to show modality. Hence, stance is a broader term than modality and modality is one linguistic device to take a stance. In this paper, I classify modality one of the subordinate categories of epistemic stance.

\subsection{Definition and categories of stance}

In order to clarify my focus, I will adopt a definition of stance as follows: Stance is an act taken by a speaker or a writer to show her/his attitude, personal evaluation, and/or feelings towards the entities or person within the social context. Drawing on DuBois (2007), Englebreston (2007) and Kiesling (2009), stance will be further divided 
into three categories: (1) evaluation and affect, (2) epistemic stance, and (3) interpersonal stance. How each kind of stance is different and how they can overlap will be discussed in this chapter.

\subsubsection{Evaluation and affect}

Evaluation and affect comprise a person's attitude, belief, value judgment, assessment, and emotion about the topic. This stance is closely related to the notion of evaluation by Thompson and Hunston (2000), which includes how one views both entities and propositions as well as the way in which one shows these views within the social context. Thompson and Hunston argue that lexical items are very clearly evaluative. They offer examples: (1) adjectives such as splendid, terrible, and important; (2) adverbs such as happily, unfortunately, and interestingly; (3) nouns such as success, failure, and tragedy; (4) verbs such as succeed, fail, win, lose, and doubt. Parallels in Japanese of these lexical items might be (1) subarashii 'splendid/great,' hidoi 'horrible,' and taisetsu 'important'; (2) shiawase ni 'happily,' zannen nagara 'unfortunately,' and omoshiroi koto ni 'interestingly'; (3) seikoo 'success,' shippai 'failure,' and higeki 'tragedy'; (4) seikoo suru 'succeed,' shippai suru 'fail,' and utagau 'doubt.'

Drawing on Labov (1972) and others, Thompson and Hunston also point out that 
grammar can be a vehicle of evaluation. Examples of grammar items that convey evaluation are (1) intensifiers, such as repetition and quantifiers; (2) comparators such as negatives, futures, and comparatives; (3) correlatives such as progressives, attributives (e.g., this big house); (4) explicatives (clauses connected by subordinators such as though, or because). Examples in Japanese of these grammatical items might be (1) nando mo nando mo 'over and over,' zenbu 'all,' or zenzen 'at all'; (2) - ja nai 'it is not -,' and $\mathrm{X}$ yori $\mathrm{Y}$ no ho ga -'Y is more - than $\mathrm{X}$ '; (3) - shite iru tokoro 'at the moment of doing' and kono ookii ie 'this big house'; (4) keredomo 'though' and kara 'because.' Thompson and Huston also point out that evaluation can be identified in a text as a whole. They argue that evaluation tends to be found throughout a text not only one particular aspect of grammar or vocabulary.

The following is a more concrete example of an utterance that shows evaluation in Japanese. Consider a woman working in an office who tries to use new software and asks her colleague how to use it. Even though her colleague explains to her how to use it, she might not understand and tell her colleague,

(1) Dame desu ne, watashi 'I am no good, you know?'

By this utterance, she is showing her evaluation, dame 'no good' on watashi, herself. It is 
important to note that what a speaker evaluates continuously changes in conversation.

What the speaker evaluates can be certain entities such as people, place, object, or the speaker's message or other participants' messages.

\subsubsection{Epistemic stance}

Epistemic stance refers to a speaker's commitment towards the message or propositional content, and how certain s/he is about the assertion. Epistemic stance includes modal verbs such as "should," "must," "would," or "might." Examples of these in Japanese include hazu 'should,' chigai nai 'must,' daroo 'would,' or ka mo shirenai 'might.' Other adverbs that show epistemic stance are "certainly," "perhaps," or "maybe." Parallels in Japanese are tashika ni 'certainly,' osoraku 'perhaps,' or tabun 'maybe.'

Other examples in Japanese are sentence-final particles such as ne or yo. In example (1), Dame desu ne, watashi 'I am not good, you know?' the particle ne is used when the speaker is asking for confirmation about the message to the interlocutor; hence, it shows the speaker's lack of full commitment to the proposition. I explain more about sentencefinal particles in 1.4.1. (Sentence-final particles).

The following is another example of epistemic stance. A couple is talking about their child. 
(2) A: Nan to naku, saikin genki ga nasasoo na ki ga suru $n$ da kedo...

'Somehow I feel that he looks like he does not have any energy lately.'

B: Daijoobu da yo. Kitto tesuto mae de tsukarete iru dake da yo. 'He is alright. I am sure that he is just tired because it is before the exam.'

In this example, $\mathrm{A}$ is conveying $\mathrm{B}$ that their son looks depressed. However, her stance indicates that she is not sure about her statement. The elements nan to naku 'somehow' and ki ga suru 'I have a feeling' show a lack of confidence about the message content. In reply to A's utterance, B takes a confident stance using kitto 'surely/ I am sure' and the sentence particle yo which shows assertiveness towards the message. These examples show how a speaker uses epistemic modality to take stances that are assertive, confident, or unsure of the propositional content of their utterances.

\subsubsection{Interpersonal stance}

Interpersonal stance shows a speaker's relationship with the interlocutor and/or the person to whom the speaker is referring. This includes the attitude a speaker shows towards the interlocutor or the referent such as respectful, humble, friendly, demanding, etc., which are mainly marked by choices among grammatical devices, word choice, and 
style choice. ${ }^{1}$ Formal and informal style, honorific expressions, humble expressions, polite expressions and giving/receiving expressions which index personal relationship in Japanese can be categorized as indicators of interpersonal stance. For instance, in the example (1), Dame desu ne, watashi 'I am no good, you know?' the speaker uses a careful style of the copula desu. This shows the speaker's stance of formality towards the listener. Consider also a worker who asks her supervisor whether she will come to the office tomorrow by saying:

(3) Ashita irrashaimasu ka? 'Are you coming tomorrow?'

In this utterance, s/he is showing her/his distance towards the listener by using an honorific verb, irassharu 'go/come' for the listener's action. It is important to note that interpersonal stance includes not only the relationship between the speaker and the listener, but also the speaker and referents to in the context. Consider two workers are talking about their supervisor, Yamada, when one of them asks the other,

(4) Yamada-san wa ashita irassharu no? 'Is Yamada-san coming tomorrow?'

This utterance indicates that the speaker is showing her/his respect/distance

\footnotetext{
${ }^{1}$ I use the terms formal/informal for what Japanese call teineigo or masu/desu, and honorific humble for what Japanese call sonkeigo and kenjôgo.
} 
towards the referent, Ms. Yamada, through the use of an honorific "irassharu" 'go/come' for the referent's action. Another interpersonal stance that we can observe in this example is the speech style at the end. Since the speaker uses casual style (no masu/desu), it can be said that the speaker is demonstrating friendliness or closeness to the listener.

Another vehicle for interpersonal stance is the expressions with benefactive verbs (giving/receiving expressions) in Japanese. For example, with an utterance such as Chichi ga tukutte kureta 'My father made it for me,' the speaker conveys her/his appreciation towards her/his father by using kureru 'give.' In this thesis, I focus on interpersonal stance and analyze how American learners of Japanese utilize expressions with benefactive verbs when they need to show a stance that indicates gratitude.

\subsubsection{How the varieties of stance overlap}

It is should be noted that the three categories of stance above are not completely separable and sometimes overlap when one is taking a stance. The following conversation is an example that shows how they can overlap. Two workers are talking about what time they should come to the office tomorrow.

(5) A: Ashita kuji de ii desu ne. '9 o'clock is good tomorrow, right?' B: Uun...moo chotto hayai hoo ga ii to omoimasu. 'Hmm..I think a little 
earlier is better.'

In the utterances above, B uses omoimasu 'think' to indicate a (not altogether complete) commitment towards the message. This is clearly epistemic stance. However, at the same time, B may be hedging and trying not to sound offensive to A by using omoimasu. This can be considered interpersonal stance, as well. My assumption is that a speaker takes a stance by utilizing different kinds of stance markers so that he/she is able to calibrate the stance that s/he wishes to project within the social context.

\subsection{Stance indicators in Japanese}

\subsubsection{Sentence-final particles}

Maynard (1997) argues that "the Japanese language is also rich in emotional expressions, which are influenced by the speaker's relationship to the psychological, social and situational context" (p. 83). Based on the data collected from the conversation between university students in Tokyo, she studies characteristics of Japanese conversation and argues that one of its remarkable features is sentence-final particles such as yo and ne. According to Maynard, yo is used when the speaker assumes that s/he has more access than the listener to the information and wants to emphasize the information in the message. On the other hand, ne is used when the speaker assumes that s/he has less 
access to the information. In other words, the choice of yo and ne can reveal how sure the speaker is about their information — all of which can be categorized as an epistemic stance. Considering the frequent use of sentence-final particles in Japanese, they play a sizeable role in stance-taking in Japanese communication.

\subsubsection{Style}

In every utterance, a Japanese speaker must opt for linguistic style when s/he speaks. Linguistic style comprises formal style and informal style. Usage of style can reveal how the speaker views the context, the topic, the addressee and bystanders. It can be said that style conveys the interpersonal relationship between the speaker and the interlocutor.

\subsubsection{Uchi-Soto indicators}

Another example of Japanese stance indicators has to do with to uchi (in-group) and soto (out-group) social structure. Drawing on the work of Nakane (1970) and others, Wetzel (1985) argues that the Japanese language encodes group identity over ego. She claims that the Japanese group orientation is observable in the word uchi (inside) meaning group or place where the speaker belongs (such as place of work, school, office, etc). These groups provide a social identity for individuals in communicative situations. 
The point that Wetzel emphasizes is that this uchi-soto distinction is a matter of constant

shifting, depending on who else is present. Linguistic indicators of this uchi-soto

distinction include benefactive verbs and honorifics. Thus, it can be said that when the

speaker takes a stance, s/he knowingly or unknowingly bases that stance on the uchi-soto

of the context. This identification with group influences the usage of expressions with

benefactive verbs and honorific and humble expressions that index interpersonal

relationships. This is yet another vehicle for interpersonal stance.

The forgoing stance indicators: sentence-final particles, style, and uchi-soto

indicators (honorific and humble expressions, benefactive verbs) are especially salient

Japanese. Yet they pose significant challenges for learners in their efforts to convey

stance. In the next section, I explain the function of benefactive verbs in Japanese, which

is one interpersonal stance indicator.

\subsection{Benefactive expressions: Giving and receiving in Japanese}

Benefactives in Japanese are a critical vehicle to convey a speaker's stance.

Pizziconi (2006) regards benefactives, as "a kind of rhetorical device that allows speakers

to construct a particular (and, crucially, culturally specific) conceptualization of human

relation" (p. 124). Benefactive verbs enable a speaker to index their beneficial 
relationship between s/he and the referent.

Wetzel's (1985) analysis defines "benefactive verbs" in the following way;

I. kureru: give to in-group;

(I a) kudasaru: give to in-group (polite: honorific);

II. ageru: give to out-group;

(II a) sashiageru: give to out-group (polite: humble);

III. morau: get from out group;

(III a) itadaku: get from out-group (polite: humble)

Benefactive verbs are also used in combination with verb gerunds to describe the giving and receiving of actions. For example, when A teaches B Chinese, B describes this situation as A-san ga chuugokugo o oshiete kureta. 'A taught Chinese to me' (lit. 'A gave me teaching Chinese'). The same frame can be expressed as A-san ni chuugokugo o oshiete moratta. 'I had B teach me Chinese,' (lit. 'I received teaching Chinese from B'). By using kureru 'give (to the speaker/in-group)' or morau 'receive (from out-group),' the speaker is able to convey that s/he benefited from the action of the giver.

Considered that use of benefactive verbs entails a speaker's appreciation towards the giver (benefactor), these expressions are indicators of interpersonal stance. For 
example, Ide's (2016) study shows that Japanese women tend to use kureru when they explain what their husband does for their children. She conducted interviews about the experience of childbirth and childrearing with three Japanese women and three American women and analyzes how their narratives differ depending on the language group. She points out that the reason why Japanese women often use kureru 'give (to uchi or me)' for their husbands' action is because they consider that childrearing is a mother's job and they want to express appreciation for what their husbands do for the children. On the other hand, American women tend to use pronouns to describe the actions of their husbands that benefit the children. They often use "we" or "my husband and I" for their experience of childrearing. Ide suggests that pronoun usage show American women's ideology regarding childrearing — it is not only a mother's job but rather involves both mother and father. Ide's study shows how a speaker takes an interpersonal stance in this case, a stance of benefaction - in their discussions of childrearing and how that stance is expressed in language use.

I emphasize that the expressions with benefactive verbs are commonly used when the speaker receives benefit from the referent, or more simply, they were affected positively by others. In Japanese: The Spoken Language Part 2 by Jordan and Noda 
(1987), it is pointed out how frequent the expressions with benefactive verbs are used in Japanese conversation. "The frequency of the pattern using a verbal of giving cannot be overestimated. Probably the greatest difficulty it poses for the foreign students is simply to remember to use it. It often occurs in Japanese when the English equivalent contains nothing parallel" (p. 114). As mentioned in their textbook, Japanese native sperkers index benefactive stance when they receive even a trivial benefit.

In order to illustrate this phenomenon more clearly, I would like to bring up an example utterance that I heard from my mother the other day. One night, I was talking with my mother over the phone. She asked about my work and I explained how hard my students study Japanese. My mother was impressed and said,

(6) Nihongo o benkyoo shite kurete, ureshii. 'I am happy that they study

Japanese (for me/us). lit. I am glad that they give me/us learning Japanese.'

It is clear that my mother did not request my students to study Japanese, nor my students study Japanese for the sake of my mother. They have never met each other and she does/will not really receive great benefit from them. However, she used kureru and took a benefactive stance. This is because she felt happy to know they are learning her language and appreciate them for making her feel happy. This example shows how a 
Japanese speaker uses benefactive verbs even for what some might see as a trivial benefit.

In this study, I focus on how learners of Japanese attempt to take a stance that reflects benefaction. Expressions with benefactive verbs are indispensable interpersonal stance indicators that a speaker shows gratitude to the giver. However, because such expressions do not really have an equivalent in English and the grammar is complex, it is assumed here that learners will misuse or fail to use the expressions. The reasons why these verbs are difficult are: (1) There are two verbs for 'give,' one of which means 'give to the speaker or speaker's in-group' and the other of which means 'give to others or speaker's out-group.'; (2) There is a single verb for 'get' requiring that the receiver to be in-group; (3) All benefactive verbs have honorific and humble forms, which compounds the uchi-soto aspect of their use; (4) All combine with gerunds to indicate benefaction. In order to explore how learners use these interpersonal stance indicators, I conducted narrative interviews with ten JFL learners and had them answer questions that could elicit expression with benefactive verbs. In the next chapter, I will discuss the research methods used in this study. 


\section{CHAPTER 2: RESEARCH METHODS}

In this chapter, I present research methods for this study, including research design, participants' information, and analytical procedure for data collection.

\subsection{Research design}

The goal of this research is to account for how American learners of Japanese take (or fail to take) an interpersonal stance using benefactive verbs in Japanese. My research questions are;

(1) Do learners use benefactive verbs?

My hypothesis is they will use benefactive verbs, but will not use them as often or in the same contexts as native speakers do.

(2) Do they fail to use benefactive verbs?

I assume learners will fail to use benefactive verbs for two reasons: (1) Similar expressions do not exist in English; (2) The grammar of [gerund +benefactive verb] is extremely complex. Therefore, I predict that learners will not be able to produce expressions with benefactive verbs in contexts where they are called for.

(3) Do they misuse benefactive verbs?

My assumption is that learners will misuse benefactive verbs because of their complexity. 
I assume that most errors will be the misuse of [gerund +benefactive verb].

Assuming that these hypothese are borne out, I will explore two additional questions:

(4) Are there any generalizations to be made about the misusage of these elements

that relate to stance indicators?

(5) What are the pedagogical implications?

In order to explore the answers to the research questions, I conducted narrative interviews with JFL learners and had them answer questions that could elicit interpersonal indicators - in other words, expressions with benefactive verbs. I transcribed the voice-recorded interviews and analyze their usage of benefactive verbs. In order to verify my analysis, I showed the transcriptions of interviews to another native speaker of Japanese to check my judgment about whether the stance indicators that are used in the interview are felicitous in the situation. The instruction as follows: Read the transcriptions of each interview and highlight that sentences that you feel giving and receiving expressions are (1) used (2) missing, or (3) misused. Giving and receiving expression includes kureru, morau, and ageru as well as their honorific/humble equivalent, kudasaru, itadaku, and sashiageru. After you highlight them, provide the verbs that you think are missing for (2) and the correct verbs for (3). 


\subsection{Participants}

Participants are ten JFL learners who are enrolled in 300- and 400-level Japanese class at Portland State University. The reason for choosing 300- and 400-level learners is that they have been introduced to benefactive verbs at least a year before the interview; thus, they are expected to be familiar with the expressions. Five participants had studied in Japan for a year and the other half had never lived in Japan. Table A reflects the information on the participants.

Table A: ${ }^{2}$ Participants' information

\begin{tabular}{lllll}
\hline No. & Name & Year in school & $\begin{array}{l}\text { Length of studying } \\
\text { Japanese }\end{array}$ & $\begin{array}{l}\text { Years of study } \\
\text { abroad in Japan }\end{array}$ \\
\hline \hline$\# 1$ & Meg & Senior & 2 years & N/A \\
$\# 2$ & John & junior & 6 years & N/A \\
$\# 3$ & Chris & Junior & 1.5 year & N/A \\
$\# 4$ & Eric & graduate & 2 years & N/A \\
$\# 5$ & Lisa & Junior & 3.5 years & N/A \\
$\# 6$ & Steve & Senior & 2 years & 1 year \\
$\# 7$ & Alex & Senior & 3 years & 1 year
\end{tabular}

2 All participants are given pseudonyms to preserve their anonymity. 


\begin{tabular}{lllll}
$\# 8$ & Brian & Senior & 2.5 years & 1 year \\
$\# 9$ & Kelly & Senior & 5.5 years & 1 year \\
$\# 10$ & Daniel & Junior & 2 years & 1 year \\
\hline
\end{tabular}

\subsection{Data collection procedure}

In order to enlist participants, I emailed students in 300- and 400-level courses a recruiting message along with a consent form. At the same time, I posted recruiting information on D2L, Portland State University's online learning system. I also made an announcement during Japanese classes that I taught. Once participants decided to join the study, I arranged a time and date and a room to conduct the interview. Each interview was conducted in a private study room at the university library. The length of each interview was about 30 minutes. The first 5 minutes were allotted for a general explanation of my study ("to analyze learner narratives") and reading through the consent form. The next 20 minutes were allotted for the actual interview. The interview was conducted in Japanese. In order to mask the specific focus of the study, the interview began with questions that aim to put participants at ease, not to elicit benefactive verbs. These questions included: (1) Tell me where you are from. (2) Where did you go to high school? (3) How long have 
you been studying Japanese? (4) How did you get interested in Japanese? After I asked these questions and had some small talk with the participant, I asked questions that aimed to elicit a benefactive stance. The questions that subjects were asked are:

(1) Who is your favorite teacher? Why? (好きな先生は誰ですか。なぜですか。)

(2) What's the best birthday you ever had? Why? (一番よかった誕生日の思い出は何 ですか。どうしてですか。）

(3) Have you been taken care of by anyone when you were studying abroad or when you were traveling? Please share your memory. (留学中や旅行中に誰かにお世話になった たことはありますか。思い出を教えてください。）

(4) Who is the most generous person you know? Why do you think so? (知っている人 の中で、誰が一番親切だと思いますか。どうしてそう思いますか。）

(5) When you face difficulties in your life, who do/ did you consult with? Why do/did you consult with this person? (人生で大変なことがあったとき、誰に相談します か。または、しましたか。どうしてこその人に相談しますか。）

(6) Who do you appreciate in your life? Please share your memory of a time when you felt appreciation/gratitude towards someone. (人生で、感謝している人は誰ですか。 その人に、感謝を感じたときの思い出を教えてください。) 
After asking the above questions, I provided about 5 minutes for feedback when they wished. This was an opportunity for the subject to ask questions about their grammar usage, etc.

In order to explore the learners' ideas about benefactive verbs, post-interviews were conducted the following term. The interviews were conducted in English and voicerecorded in a private study room in the library. The questions that I asked during postinterviews are: (1) What kind of feelings or a stance can you project by using benefactive verbs? (2)When do you think you are supposed to use the expressions? (3) Do you consider these expressions difficult? (4) Do you feel comfortable using them?

\subsection{Analytical procedure for the interview}

The interviews were voice-recorded, transcribed and analyzed in order to identify how learners use, misuse, or don't use benefactive verbs. After I conducted interviews with participants, I transcribed the interviews (using pseudonyms for the speakers and the referents) and examined what linguistic devices that speakers were using and how they revealed their stance via language - again with a focus on benefactive verbs. After analyzing the data myself, I showed the interviews' transcription to another Japanese native speaker and had that person judge the expressions. The objective was to verify my 
judgment that the stance indicators that used in the interview were (in)correct or (in)appropriate. 


\title{
CHAPTER 3:
}

\begin{abstract}
ANALYSIS
The purpose of this chapter is to analyze the data and explore the results of my research questions; (1) Do learners use benefactive verbs? (2) Do they fail to use benefactive verbs? (3) Do they misuse benefactive verbs?

\subsection{Do learners use benefactive verbs?}

The first research question is, "Do learners use benefactive verbs to acknowledge indebtedness?" I hypothesized that this would be the case and results bore this out. Learners do use benefactive verbs to show benefaction based on the current data. In fact, ALL subjects used benefactive verbs correctly, or incorrectly at some point in their interviews.
\end{abstract}

Table B on the following page shows how many times each subject used expressions with benefactive verbs. In the table, “Object + " indicates expressions that only involve giving/receiving an object such as hon o kureta 's/he gave me a book' or hon o moratta 'I got a book.' On the other hand, "Gerund +" shows expressions with verb gerunds, such as hon o katte kureta. 'S/he bought a book for me.' (lit. 'S/he gave me an act of buying a book.') or hon o katte moratta. 'I had her/him buy me a book.' (lit. 'I received an action of her/him buying me a book.') The numbers in the gray boxes show 
how many times each subject used expressions with benefactive verbs. The column on

the far right, "total opportunities," indicates the total numbers of chances that each

subject had to use the benefactive verbs.

Table: B Use of benefactive verbs-data summary

\begin{tabular}{|c|c|c|c|c|c|c|c|c|c|c|c|}
\hline \multirow{2}{*}{ No\# } & \multirow{2}{*}{ Name } & \multirow{2}{*}{\begin{tabular}{|c|}
$\begin{array}{c}\text { Length } \\
\text { of } \\
\text { studying } \\
\text { JPN }\end{array}$ \\
\end{tabular}} & \multirow{2}{*}{$\begin{array}{c}\text { Length } \\
\text { of } \\
\text { study } \\
\text { abroad } \\
\end{array}$} & \multicolumn{2}{|c|}{$\begin{array}{c}\text { Kureru } \\
\text { Kudasaru }\end{array}$} & \multicolumn{2}{|c|}{$\begin{array}{l}\text { Morau, } \\
\text { Itadaku }\end{array}$} & \multicolumn{2}{|c|}{$\begin{array}{c}\text { Ageru } \\
\text { Sashiageru } \\
\end{array}$} & \multirow[b]{2}{*}{$\begin{array}{c}\text { Total } \\
\text { usages }\end{array}$} & \multirow{2}{*}{\begin{tabular}{|c|} 
Total \\
opport- \\
unities \\
\end{tabular}} \\
\hline & & & & Object + & Gerund+ & Object + & Gerund+ & Object + & Gerund+ & & \\
\hline$\# 1$ & Meg & 2 & 0 & 4 & 0 & 0 & 0 & 0 & 3 & 7 & 14 \\
\hline$\# 2$ & John & 6 & 0 & 0 & 0 & 0 & 0 & 3 & 0 & 3 & 13 \\
\hline$\# 3$ & Chris & 1.5 & 0 & 1 & 6 & 0 & 0 & 0 & 4 & 11 & 13 \\
\hline$\# 4$ & Eric & 2 & 0 & 3 & 4 & 0 & 0 & 0 & 0 & 7 & 14 \\
\hline$\# 5$ & Lisa & 3.5 & 0 & 0 & 3 & 0 & 0 & 0 & 0 & 3 & 14 \\
\hline \#6 & Steve & 2 & 1 & 0 & 3 & 0 & 0 & 1 & 0 & 4 & 9 \\
\hline$\# 7$ & Alex & 3 & 1 & 0 & 8 & 2 & 1 & 0 & 2 & 13 & 17 \\
\hline$\# 8$ & Brian & 2.5 & 1 & 1 & 1 & 2 & 3 & $\underline{0}$ & 0 & 7 & 11 \\
\hline$\# 9$ & Kelly & 5.5 & 1 & 0 & 1 & 0 & 0 & 0 & 2 & 3 & 6 \\
\hline$\# 10$ & Daniel & 2 & 1 & 2 & 1 & 2 & 4 & 1 & 0 & 10 & 16 \\
\hline & Total & 30 & 5 & 11 & 27 & 6 & 8 & 5 & 11 & 68 & 127 \\
\hline & Average & 3 & 0.5 & 1.1 & 2.7 & 0.6 & 0.8 & 0.5 & 1.1 & 6.8 & 12.7 \\
\hline
\end{tabular}

As table B shows, all subjects except for \#2 John used either kureru or morau at some

point in the interview. The expression the participants used the most was [gerund+kureru]

for a total of 27 times.

The interview with Alex shows relatively successful usage of benefactive verbs.

Alex has been studying Japanese for about three years and lived in Japan for a year. His

Japanese proficiency is one of the highest in the 400-level course. Alex used benefactive 
verbs most often (13 times in total) in the interview among all subjects.

The following excerpt comes from his answer to who he thinks is the most generous person around him when he started to talk about his Japanese friend called Emi.

He explains that she helped him in Japan quite often, including taking him to the city hall to help him fill out his paperwork. He mentions that it was hard for him to get it done by himself because he was not familiar with the system and the paperwork had many kanji that he could not read. In the example, he uses [verb gerund + kureru] as he explains what she did for him.

[Excerpt 1: Alex]

(1) Alex：なんか、本当によ゙うやって言えばいいか全然知りませんでした。 Nanka hontoo ni doo yatte ieba ii ka zenzen shirimasen deshita.

（2）だから、なんか、えみさんがなんか、付き合ってくれました。 Dakara, nanka, Emi san ga nanka, tsukiatte kuremashita.

$$
\text { なんか、一緒に行こうって。で、そのあと、なんか、 }
$$

Nanka, issho ni ikoo tte. De, sono ato, nanka,

なんでも質問でもありましたら、全然連絡してくださいって Nan demo shitsumon demo arimashitara, zenzen renraku shite kudasai tte

言ってくれましたし、なんかいつも Itte kuremashita shi, nanka itsu mo

元気?日本の生活大変じゃないですかって。 Genki? Nihon no seikatsu taihen ja nai desu ka tte.

大丈夫、大丈夫、大丈夫って、 Daijoobu, daijoobu, daijoobu tte, 
[English Translation]

(1) Alex: Well, I really did not know how to speak at all.

(2) So, um, Emi kept + kureremashita me company.

(3) Like, let's go together (she said). Then, after that, well,

(4) If you have any questions, please contact me,

(5) she said + kuremashita, and always like,

(6) How are you? Isn't life in Japan hard?

(7) It is okay, it's okay, it's okay (she said)

(8) Like, she is always, like, accepted +kuremashita my requests.

In the excerpt above, Alex uses [verb gerund + kureu] three times in a relatively short

narrative. In fact, in the excerpt, he uses [verb gerund + kureru] every time he describes

actions that the referent took on his behalf, which are in line (2), tsukiatte 'keep company

-,' (5) itte ‘say,' and (8) hikiukete 'take over -.' Those usages are all grammatically

correct. By utilizing these expressions, he expressed his gratitude to the referent, Emi. In

other words, he succeeded in showing his benefactive stance in the narrative. In the post-

interview, Alex told me that he found the expressions with benefactive verbs are

relatively easy to control for him and he is comfortable with using them in conversation.

He explained that he uses benefactive verbs whenever he explains an event where he

gained some benefit from others; he says he is able to use them automatically. In fact,

there were no hesitations before he used the expressions. He also mentioned that he 
believes that showing appreciation to others is very important in Japanese society where the concept of omoiyari 'empathy' and ongaeshi 'reciprocation' are prevalent.

The next example is from the interview with Daniel, who also has experience of studying in Japan for one year. In this excerpt, he uses benefactive verbs (kureru and morau) with the gerund of oshieru 'teach.' In this excerpt, he is talking about a professor at his university who helped him when he started to work on his graduation thesis. [Excerpt 2: Daniel]

(1) Daniel: よく日本の資料を教えてもらって、と Yoku nihon no shiryoo o oshiete moratte, to 昔の日本の書き方を、教えて、教えました、教えてもらった。 Mukashi no nihon no kakikata o, oshiete, oshiemashita, oshiete moratta.

(3) Takizawa: あ、そうなんですか。へー。

A, soo nan desu ka. Hee,

(4) Daniel: 例えば、古いの、ま、えー、30 年代の、ぐらいの

Tatoeba, furui no, ma, ee, sanjuu nendai no, gurai no.

$$
\text { か、書き方は、いろいろ中国の漢字を使う。 }
$$
Ka, kaki kata wa iroro chuugoku no kanji o tsukau. 今、違う漢字を使っていますけどそれがわかりませんでしたから、 Ima, chigau kanji o tsukatte imasu kedo sore ga wakarimasen deshita kara, その先生が教えてくれた。 Sono sensei ga oshiete kureta.

[English Translation]

(1) Daniel: And I often had +moratte him teach me about Japanese documents, and He teach (gerund), taught, I had +moratta him teach me about the old 
Japanese writing system.

(3) Takizawa: Oh, is that so? Hmm.

(4) Daniel: For example, old ones, from around thirties'. The writing system, they used various Chinese characters. (They) use different kanji now, but I did not about it. So, the teacher taught + kurerta me.

Using a combination of gerund of oshieru 'teach' and morau, he attempts to project his stance towards his professor in line (1), (2), and (7). In line (2), we can observe that he is self-monitoring in his grammar use. He first says oshiete which is a gerund form of oshieru 'teach' and immediately follows with oshiemashita 'taught' in past tense, formal style. Finally, he says oshiete moratta 'received teaching' in informal style. What might have been better here was oshiete moraimashita, which is the formal style of oshiete moratta because he is talking with someone higher-ranking (the interviewer is his teacher). Similarly, he finishes his sentence in line (7) in informal style: oshiete kureta, 'gave teaching (informal style)' where oshiete kuremashita 'gave teaching' (formal style) would have been preferable. This excerpt implies that he is aware and able to use benefactive verbs; however, he fails to use other interpersonal indicators, informal/formal style in this case. This demonstrates the difficulties that learners face when they need to show multiple interpersonal stances simultaneously - in this case, one for the referent and the other for the interlocutor. 
Although there were a number of correct usages of benefactive verbs in the interviews, some subjects were halting in their use of expressions with benefactive verbs. The following excerpt, from the interview with Eric, is a good example. Before this excerpt, I asked who he thinks is a generous person and he started to talk about his friend. Eric explained that Meg, who is a friend from his college, is generous because she listens to people and gives them good advice.

[Excerpt 3: Eric]

(1) Eric: えー、大学の友達のメグさんだと思います。 Eee, daigaku no tomodachi no Megu-san da to omoimasu.

$$
\text { えと、メグさんは、う一ん、えつと[10sec]いつもほかの人の悩みを }
$$
Eto, Megu san wa uun, etto [10sec]itsu mo hoka no hito no hito no nayami o

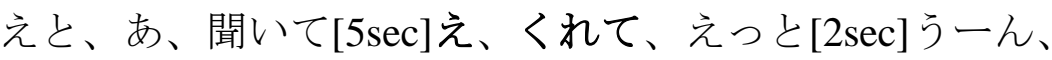
Eto, a, kiite [5sec] um, kurete, etto [2sec] unn

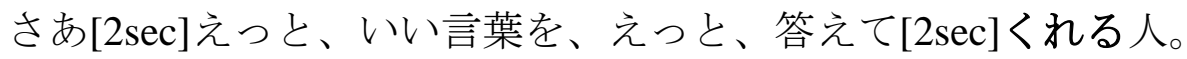
Saa [2sec] etto ii kotoba o, etto, kotaete [2sec] kureru hito.

[English translation]

(1) Eric: Hmm, I think it will be Meg, a friend from college.

(2) Um, Megu, umm, well always, other's worries,

(3) Well, um...she listens [5sec] $\mathrm{oh}$, kurete, um....

(4) Well [2sec]umm, she is a person who tells [2sec] kureru good words.

Eric halted quite often throughout the interview but it was significant that he attempted to use kurete in line (3). He took 5 seconds to utter kurete. Thus even though this learner is 
aware of these expressions, he is not able to produce them automatically.

The following excerpt from Chris's interview shows a similar example of halting delivery when using benefactive verbs. Before the excerpt, I asked him who he consults with when he faces difficulties in his life, and he started to talk about his father who gives him good advice when he has problems.

[Excerpt 4: Chris]

(1) Chris: ま、その大きな問題誰にも相談していませんけど、 Ma, sono ookina mondai, dare ni mo soodan shite imasen kedo,

$$
\text { ああ、時々父だと思います。 }
$$
Aa, tokidoki chichi da to omoimasu.

父はいつもいいアドバイスを教えて

Chichi wa itsu mo ii adobaisu o oshiete

[2.5sec]あ、く、くれています。 [2.5sec] a, ku kurete imasu.

[English Translation]

(1) Chis: Well, I do not consult with anyone about the big problems, Oh, sometimes my father, I suppose.

My father always teaches me [2.5sec] oh, $\boldsymbol{k u}, \boldsymbol{k u}$ kurete imasu.

In line (3), Chris took 2.5 seconds to utter kureru in a halting manner. Chris maintained good fluency during interview, but he often halted before he produced kureru. Again, this example shows lack of full control when producing expressions with benefactive verbs. 
In sum, learners do use benefactive verbs; however, some difficulties were

observed. These include utilizing multiple stance indicators in the same context and generating the expression automatically.

\subsection{Do learners fail to use benefactive verbs?}

The second question is, "Do learners fail to use benefactive verbs?" In the last chapter, I hypothesized that they are inclined to fail to use benefactive verbs due to the expressions' complexity and lack of existence of similar expressions in English. The current data show that learners do fail to use benefactive verbs to show benefaction towards the referents in the context.

The data indicate that learners fail to use benefactive verbs frequently. In fact, all subjects failed to use them in a number of instances during their interviews. Table $\mathrm{C}$ on the following page shows the numbers of times that learners failed to use benefactive verbs when it would have been felicitous to do so. The numbers in the gray boxes on the right side show the total numbers of times each subject failed to use benefactive verbs. The data show that subjects failed to produce benefactive verbs an average of 5.9 times during their interviews. As the data show, the number that they failed to use [gerund + kurereu] is the most frequent which is a total of 51 times. 
Table C: Failure to use benefactive verbs-data summary

\begin{tabular}{|c|c|c|c|c|c|c|c|c|c|c|c|}
\hline \multirow{2}{*}{ No\# } & \multirow{2}{*}{ Name } & \multirow{2}{*}{\begin{tabular}{|c|}
$\begin{array}{c}\text { Length } \\
\text { of } \\
\text { studying } \\
\text { JPN }\end{array}$ \\
\end{tabular}} & \multirow{2}{*}{$\begin{array}{c}\text { Length } \\
\text { of } \\
\text { study } \\
\text { abroad }\end{array}$} & \multicolumn{2}{|c|}{$\begin{array}{c}\text { Kureru } \\
\text { Kudasaru }\end{array}$} & \multicolumn{2}{|c|}{$\begin{array}{l}\text { Morau, } \\
\text { Itadaku }\end{array}$} & \multicolumn{2}{|c|}{$\begin{array}{c}\text { Ageru } \\
\text { Sashiageru }\end{array}$} & \multirow{2}{*}{$\begin{array}{c}\text { Total } \\
\text { Failure }\end{array}$} & \multirow{2}{*}{$\begin{array}{c}\text { Total } \\
\text { opport- } \\
\text { unities }\end{array}$} \\
\hline & & & & Object + & Gerund+ & Object + & Gerund+ & Object + & Gerund+ & & \\
\hline \#1 & Meg & 2 & 0 & 0 & 7 & 0 & 0 & 0 & 0 & 7 & 14 \\
\hline \#2 & John & 6 & 0 & 0 & 9 & 0 & 0 & 0 & 1 & 10 & 13 \\
\hline \#3 & Chris & 1.5 & 0 & 0 & 0 & 0 & 1 & 0 & 1 & 2 & 13 \\
\hline \#4 & Eric & 2 & 0 & 0 & 5 & 0 & 2 & 0 & 0 & 7 & 14 \\
\hline \#5 & Lisa & 3.5 & 0 & 0 & 10 & 0 & 0 & 0 & 1 & 11 & 14 \\
\hline \#6 & Steve & 2 & 1 & 0 & 3 & 0 & 0 & 0 & 2 & 5 & 9 \\
\hline \#7 & Alex & 3 & 1 & 0 & 4 & 0 & 0 & 0 & 0 & 4 & 17 \\
\hline \#8 & Brian & 2.5 & 1 & 0 & 4 & 0 & 0 & 0 & 0 & 4 & 11 \\
\hline \#9 & Kelly & 5.5 & 1 & 0 & 3 & 0 & $\underline{0}$ & 0 & 0 & 3 & 6 \\
\hline$\# 10$ & Daniel & 2 & 1 & 0 & 6 & 0 & 0 & 0 & 0 & 6 & 16 \\
\hline & Total & 30 & 5 & 0 & 51 & 0 & 3 & 0 & 5 & 59 & 127 \\
\hline & Average & 3 & 0.5 & 0 & 5.1 & 0 & 0.3 & 0 & 0.5 & 5.9 & 12.7 \\
\hline
\end{tabular}

Alex, who used [gerund+ kureru] the most among the participants still failed to

use it occasionally during the interview. One of the examples is the following excerpt. I

asked Alex who he appreciates the most and he named his mother. He started to talk

about his mother, who is a single mother and worked hard to raise him.

[Excerpt 5: Alex]

(1) Alex： えーっと、一番感謝しているのは...

Eetto, ichiban kansya shiteiru no wa

$$
\text { うーん、どうですかねえ }
$$

Uun, doo desu ka ne...

まあ、結局お母さんじゃないですか。 Maa, kekkyoku okaasan janai desu ka. 
(4) Takizawa: ふーん。

Fuun.

(5) Alex: 本当に、なんか、九ヶ月風邪をひきながら、 Hontoo ni, nanka, kyuu kagetsu kaze o hiki nagara, なんか僕を、なんか生んでましたね。 Nanka boku o nanka undemashita ne.

そう、シングルマザーで、 Soo, shinguru mazaa de, 毎日毎日自分のために働いてきました。 Mainichi mainichi jibun no tameni hataraite kimashita.

だから、一番感謝しているのは、お母さんでおります。 Dakara, ichiban kansha shite iru no wa okaasan de orimasu.

[English Translation]

(1) Alex: Well, the person I appreciate the most is... Hmm, I wonder...

(4) Takizawa: Hmm.

(5) Alex: Honestly, like, while being sick for 9 months, Like, she gave a birth to me, you know. Yeah, as a single mother, She has worked for myself every single day. So, the person I appreciate the most is my mother.

In this excerpt, although Alex was talking about who he appreciates the most, he did not use any benefactive verbs. To native speakers of Japanese, line (6) and (8) sound infelicitous due to lack of benefactive verbs. In line (6), he said undemashita 'giving birth' in reference to his mother. Here, it would have been ideal to use a benefactive verb: unde (giving a birth) + kuremashita to show his benefactive stance clearly. Similarly, in 
line (8), Alex said hataraite kimashita '(she) has worked," where he would have been able to show his benefactive stance by utilizing [gerund + kureru]: hataraite (work) + kuremashita. Although he failed to utilize benefactive verbs in this excerpt, he still attempted to take a stance. In line (9), he uttered jibun no tame ni 'for the sake of myself.' This shows his intention to project a benefactive stance. Nevertheless, failing to finalize the sentence with a benefactive verb resulted in his utterance sound infelicitous. Another remarkable finding was leaners' tendency to use evaluative words such as adjectives to show their stance while failing to use benefactive verbs. One of the examples is from the interview with John. In this excerpt, I asked him if he had a memorable birthday when he was a child, or when he was in high school. He started to talk about how his parents would throw big parties for him when he was little.

[Excerpt 6: John]

(1) Takizawa: じゃあ、例えば小さいころとか、高校生のころとか。 Jaa, tatoeba chiisai koro toka, kookoosee no koro toka.

(2) John:＼cjkstart親は大きいパーティをしました。 Oya wa ookii paati o shimashita.

(3) Takizawa: ああ、そうですか。 Aa, soo desu ka.

(4) John:＼cjkstart毎年。親はいい親ですよ。 Maitoshi. Oya wa ii oya desu yo. 
[English translation]

(1) Takizawa: Then, for example, when you were a child, or when you were in high school?

(2) John: My parents did a big party.

(3) Takizawa: Oh, is that so?

(4) John: $\quad$ Every year. My parents are good parents.

John could have used an expression with a benefactive verb in line (2) to show his

gratitude towards his parents. In this line, he was trying to explain his parents threw

parties for him, but it almost sounds as if his parents had the party for themselves, not for

the sake of John. Again, this is due to a lack of a benefactive verb. It would have been

ideal to say Oya wa paati o shite + kuremashita. 'My parents had a party for me.'

Although he did not his show a benefactive stance in line (2), he still attempted to show

the stance in line (4), saying Oya wa ii oya desu yo. 'My parents are good parents.' The

adjective, $i i$ 'good' is clearly his evaluation of his parents. This implies that a learner

might attempt to take a stance through some other construction, but fails to use

benefactive verbs.

In excerpts 5 and 6 , both participants failed to use benefactive verbs. However,

they both attempted to project their stance by using stance indicators other than

benefactive verbs: an adverb, tame $n i$ 'for the sake of' and an adjective, $i i$ 'good.' Both 
examples suggest that learners are inclined to fail to use benefactive verbs, but they still attempt to compensate stance-taking by using other kinds of stance indicators. A similar example was observed in the interview with Lisa. In this excerpt, I questioned who she thinks is the most generous person she knows and she answered that her boyfriend is generous. I asked when she feels so and then she started to talk about what he does for her.

[Excerpt 7: Lisa]

(1) Takizawa: じゃあ、どんなときに、親切だなーとか、 Jaa, donna toki ni, shinsetsu da naa toka

(3) Lisa: はい、あの、いつも、小さいことを、彼はします。 Hai, ano, itsu mo, chiisai koto o kare wa shimasu.

$$
\begin{aligned}
& \text { やさしいなーって思いますか? } \\
& \text { Yasashii naa tte omoimasu ka? }
\end{aligned}
$$


(1) Takizawa: Then, when he is generous or,

(2) kind you think?

(3) Lisa: Well, um, always, he does small stuff.

(4) Sometimes, um, he cleans.

(5) I don't like to clean so,

(6) Um, he is always like please leave it up to me.

(7) I (say) thank you.

(8) Haha, it is small kindness but very precious.

From the excerpt as a whole, we can perceive that Lisa regards her boyfriend as kind and generous. However, Lisa did not use any benefactive verbs when she described what her boyfriend does for her. To native speakers of Japanese, line (3) and line (4) sound infelicitous, again because of the lack of benefactive verbs. For both lines, it would have been ideal to use [gerund + kureru]: shite kuremasu 'he does it for me.' She failed to use benefactive verbs to show gratitude, but she attempted to project her stance in (7) and line (8). In line (7), she is taking her stance by uttering a ritual expression, Arigatoo gizaimasu 'Thank you,' which is normally used when a speaker shows her/his gratitude to the interlocutor in person. Furthermore, she evaluated her boyfriend's behavior in line

\section{(8), Chiisai shinsetsu desu kedo, totemo taisetsu desu. 'It is small kindness but very}

precious.' Both shinsetu 'kindness' and taisetsu 'precious' are evaluative words which show the speaker's gratitude towards the referent. This excerpt shows one learner's strategy, showing benefactive stance by uttering ritual expressions in talking about the 
referent.

Another similar example was observed during the interview with Kelly. She has studied Japanese for five and a half years. She also has experience of study abroad in Japan for a year. Before this excerpt, I asked her about her favorite teacher. She answered that would be her Japanese teacher when she was studying in Japan. I asked why she thinks so and she started to describe the teacher in a halting manner.

[Excerpt 8: Kelly]

(1) Kelly: なんか、先生は、よく、あの、時間、 Nanka, sensee wa yoku ano, jikan

$$
\begin{aligned}
& \text { よく、なんだ、うーん } \\
& \text { Yoku, nanda, uun }
\end{aligned}
$$
いつでもたすけ、助けることができますから。 Itsu de mo tasuke, tasukeru koto ga dekimasu kara.

いつでも、今、なん、いつでも、いつでも、 Itsu de mo, ima, nan, itsu de mo, itsu de mo 時間があるから ...う一ん、あ、時間があっ ...たり、 Jikan ga aru kara... uun, a, jikan ga a.. ttari なんかすごくやさしい人、だし、う一ん、 Nanka sugoku yasashii hito da shi, uun, なんか先生の授業はいつも楽しかったです。 Nanka sensee no jugyoo wa itsu mo tanoshikatta desu.

[English translation]

(1) Kelly: Well, the teacher often um, time,

(2) Often, you know, umm. 
Always help, can help so.

Always, now, any, whenever,

She has time... umm, oh, she had...time and

Like very kind person and, umm,

Well, the teacher's class was always fun.

Similar to the last three excerpts, there is no benefactive verb used here. In line (3), she is

telling how her teacher "can" help. Instead of the potential expression, it would have been

best to use [verb gerund + kureru]: tasukete kuremasu 'helps me.' In both line (6) and (7),

she gave an evaluation of her teacher saying she was kind and her class was enjoyable.

Again, this is another example of how a learner takes a stance via evaluation.

In sum, it is very common for learners to fail to use expressions with benefactive

verbs. However, other strategies of stance-taking have been observed: using evaluative

adjectives and adverbs, a ritual expression that shows gratitude, and potential

expressions. Nevertheless, it is important to note that even though one attempts to take a

stance utilizing other kinds of stance indicators, it still sounds infelicitous if there are no

benefactive verbs in a speaker's comments about what the referent did for her/him.

\subsection{Do learners misuse benefactive verbs?}

The third research question is, "Do learners misuse benefactive verbs?" I

hypothesized that this would be the case due to the grammatical complexity of these 
expressions; there are two verbs for 'give,' kureru and ageru; all have honorific and humble forms, and; all can combine with gerunds to indicate benefaction. In fact, the current data show that learners do misuse benefactive verbs when they display indebtedness towards the referent.

Table D on the next page shows how many times each subject made errors on when they uttered expressions with benefactive verbs. The numbers in the gray boxes on the right show how many times each subject misused the expressions. They made errors regarding benefactive verbs an average of 1.8 times. One of the errors that I expected to be common was that learners would overgeneralize ageru 'give to out-group.' As I assumed, some learners did use ageru when they were supposed to use kureru. However, this error was not as frequent as I expected. This error happened only five times among all interviews with all subjects and there were only two subjects who made this error: John and Chris. 
Table D: Misuse of benefactive verbs-data summary

\begin{tabular}{|c|c|c|c|c|c|c|c|c|c|c|c|}
\hline \multirow{2}{*}{ No\# } & \multirow{2}{*}{ Name } & \multirow{2}{*}{\begin{tabular}{|c|}
$\begin{array}{c}\text { Length } \\
\text { of } \\
\text { studying } \\
\text { JPN }\end{array}$ \\
\end{tabular}} & \multirow{2}{*}{$\begin{array}{c}\begin{array}{c}\text { Length } \\
\text { of } \\
\text { study } \\
\text { abroad }\end{array} \\
\end{array}$} & \multicolumn{2}{|c|}{$\begin{array}{c}\text { Kureru } \\
\text { Kudasaru }\end{array}$} & \multicolumn{2}{|c|}{$\begin{array}{l}\text { Morau, } \\
\text { Itadaku }\end{array}$} & \multicolumn{2}{|c|}{$\begin{array}{c}\text { Ageru } \\
\text { Sashiageru }\end{array}$} & \multirow[b]{2}{*}{\begin{tabular}{|c|} 
Total \\
mistakes
\end{tabular}} & \multirow{2}{*}{$\begin{array}{c}\text { Total } \\
\text { opport- } \\
\text { unities }\end{array}$} \\
\hline & & & & Object + & Gerund + & Object + & Gerund+ & Object + & Gerund+ & & \\
\hline$\# 1$ & Meg & 2 & 0 & 2 & 0 & 0 & 0 & 0 & 0 & 2 & 14 \\
\hline$\# 2$ & John & 6 & 0 & 0 & 0 & 0 & 0 & 3 & 0 & 3 & 13 \\
\hline$\# 3$ & Chris & 1.5 & 0 & 0 & 1 & 0 & 0 & 0 & 2 & 3 & 13 \\
\hline$\# 4$ & Eric & 2 & 0 & 0 & 0 & 0 & 0 & 0 & 0 & 0 & 14 \\
\hline$\# 5$ & Lisa & 3.5 & 0 & 0 & 2 & 0 & 0 & 0 & 0 & 2 & 14 \\
\hline$\# 6$ & Steve & 2 & 1 & 0 & 1 & 0 & 0 & 0 & 1 & 2 & 9 \\
\hline$\# 7$ & Alex & 3 & 1 & 0 & 0 & 0 & 0 & 0 & 0 & 0 & 17 \\
\hline$\# 8$ & Brian & 2.5 & 1 & 0 & 0 & 0 & 2 & 0 & 0 & 2 & 11 \\
\hline$\# 9$ & Kelly & 5.5 & 1 & 0 & 0 & 0 & 0 & 0 & 0 & 0 & 6 \\
\hline$\# 10$ & Daniel & 2 & 1 & 2 & 0 & 1 & 0 & 1 & 0 & 4 & 16 \\
\hline & Total & 30 & 5 & 4 & 4 & 1 & 2 & 4 & 3 & 18 & 127 \\
\hline & Average & 3 & 0.5 & 0.4 & 0.4 & 0.1 & 0.2 & 0.4 & 0.3 & 1.8 & 12.7 \\
\hline
\end{tabular}

The following excerpt is typical of overgeneralization of ageru. Chris is a 300-

level Japanese student and has been learning Japanese for about a year and a half. I asked

him who he appreciates the most and he named his father and his teacher.

[Excerpt 9: Chris]

(1) Takizwa: 誰に一番感謝していますか?

Dare ni ichiban kansha shite imasu ka?

(2) Chris: 父と先生。

Chichi to sensei.

(3) Takizawa: あ、そうですか。

A, soo desu ka.

じやあ、どうしてお父さん?

Jaa, doo shite otoosan? 
(5) Chris: 父は、まあ...

Chichi wa, maa...

例えば、まあ、金がなければ、

Tatoeba, maa, okane ga nakereba

この大学に行けないはずだったのに、

Kono daigaku ni ikenai hazu datta no ni

父が手伝ってあげました。

Chichi ga tetsudatte agemashita.

[English translation]

(1) Takizawa: Who do you appreciate the most?

(2) Chris: My father and teachers.

(3) Takizawa: Oh is that so?

Then, why your father?

(5) Chis: $\quad$ My father, well...

For example, well, if it were not for money,

I should not be able to go to this college, but, My father supported + agemashita.

In this excerpt, Chris is explaining how he appreciates his father for supporting him to go

to college. In line (6) and (7), a number of expressions that he learned in 200 and 300

Japanese class were utilized: negative of provisional form nakereba 'if it were not for,'

potential verb ikenai 'is not able to go,' hazu 'should not,' and no ni 'in spite of.' Chris

utilized those grammatical devices correctly. However, in line (8), he used the incorrect

benefactive verb; he used ageru instead of kureru. Chris is the receiver of the action in

the context, hence, it is correct to use tetsudatte kuremashita '(my father) supported me.' 
Chris made the same error three times in total during the interview. Even though he has good control of other expressions that he learned in 300-level Japanese class, such as provisional form or potential verbs, he still makes errors in benefactive verbs which were introduced in the 200-level Japanese class. These data demonstrate how hard the expressions can be for learners to fully acquire.

Other than overgeneralization of ageru, some errors in grammatical forms were observed. The following excerpt gives us one of the the typical examples. Before the excerpt, I asked Brian whom he appreciates the most, and he named his teacher, Mr.

Suzuki. He explained that Mr.Suzuki took care of him and I asked him to elaborate.

[Excerpt 10: Brian]

(1) Takizawa: じゃ、鈴木先生はどんな、あの、お世話になったっていうのは Ja, suzuki sensei wa, donna, ano, osewa ni natta tte iu no wa, 例えばじんなことをお世話になったんですか? Tatoeba, donna koto o osewa ni natta $n$ desu ka?

(3) Brian: まあ、おたしは、そのときに Maa, watashi wa sono toki ni わたしは日本語の 1 年生でしたから、 Watashi wa nihongo no ichi nensei deshita kara, 私は鈴木先生と TA オフィスに先生に行って、 Watashi wa Suzuki sensei to TA ofisu ni itte, えーと、宿題とかを手伝いもらいました。 Eeto, shukudai toka o tetsudai moraimashita. 
(7) Takizawa: ふーん、なるほどね。

Huun, naruhodo ne.

(8) Brian: [whisper] 手伝ってもらいました。

[whisper] Testudatte moraimashita.

[English Translation]

(1) Takizawa: Then, Suzuki-sensei, what kind, umm, when you say he took care,

For instance, what kind of things did he take care for you?

(3) Brian: Well, I, back then,

(4) I was in the first year of Japanese class, so,

(5) I would go to the TA office with Suzuki-sensei and,

(6) Umm, I have him help (stem) + moraimashita my homework, etc.

(7) Takizawa: Hmm, I see.

(8) Brian: [whisper] I had him help (gerund) + moraimashita.

In line (6), Brian explained how his teacher helped him with his assignments and said

tetsudai moraimashita 'received help,' yet, this is grammatically incorrect. Testudai is

the stem form of the verb tetsudau 'help.' Benefactive verbs are conjugated with the

gerund from - in this case, tetsudatte. He made an error in line (9), saying tesudai

moraimashita where tetsudatte moraimashita would have been correct. Nevertheless,

immediately after the interviewer said naruhodo ne 'I see,' Brian corrected his former

utterance whispering, testudatte moraimashita with a gerund form. According to Kormos

(1999), who explored the self-repair in the second language by reviewing the

psycholinguistic research on self-repair, "Self-corrections are overt manifestations of the

monitoring process" (p. 315). That is to say, his self-correction of the benefactive verb in 
line (8) shows how a learner monitors his own language use.

Thus far, I have analyzed two kinds of misusage: overgeneralizing of ageru and using an incorrect verb form before benefactive verbs. Another typical error that I observed is using an incorrect particle for the benefactive verbs. The following excerpt from Steve's interview gives us a typical example. Steve has been studying Japanese for the last two years and studied in Japan for a year. Before the excerpt, I asked him if there was any person who took care of him while he was in Japan. Steve started to talk about his program director, Tanaka-san, who helped him when he was an international student.

[Excerpt 11: Steve]

(1) Steve: お世話になった人は、田中さんです。 Osewa ni natta hito wa, Tanaka san desu. 田中さんは、あ一、大阪大学の、う一ん、 Tanaka-san wa, aa, oosaka-daigaku no, unn, 国際学生センターのプログラムディレクターです。 Kokusai gakusee sentaa no puroguramu direkutaa desu. あ一、留学生が、質問があったら、あ、田中さん、に聞いて、 Aa, ryuugakusee ga shitsumon ga attara, a, Tanaka san ni kiite,

田中さん、あー、が? 田中さんに？

Tanaka san, aa, ga? Tanaka-san ni?

\section{手伝ってくださいます。} Tetsudatte kudasaimasu.

[English translation]

(1) Steve: The person who took care of me, is Tanaka-san. 
(2) Tanaka-san is, umm, Osaka University's umm,

(3) Program director of the international student center.

(4) Umm, when the international students have questions, ah, ask Tanaka-san,

(5) Tanaka-san, umm, is (ga)? For (ni) Tanaka-san?

(6) Help us + kudasaimasu.

His rising tone in line (5) shows his uncertainty of which particle he should use, either $\boldsymbol{g a}$

or $\boldsymbol{n i}$. In this line, Steve is attempting to explain he appreciates Tanaka-san for helping the international students. There are two possible ways to describe this context:

I. Tanaka-san ga tasukete kuremasu/kudasaimasu.

'Tanaka-san helps us.' (lit. 'Tanaka-san give us helping')

II. Tanakasan ni tasukete moraimasu/itadakimasu.

'(We) had Tanaka-san help us' (lit.'We receive helping fromTanaka-san.')

As the first sentence shows, if the speaker is using kuremasu/ kudasaimasu 'give to ingroup,' s/he needs to mark Tanaka-san as the subject of the action by using subject marker $g \boldsymbol{a}$. On the other hand, as the latter example shows, if the speaker is using moraimasu/itadakimasu 'in-group receives,' s/he needs to mark Tanaka-san as the starting point of the action by using particle ni. Hence, in the excerpt above, since Steve is using kudasaimasu 'give to in-group,' marking Tanaka-san as the subject using particle ga would be the correct usage. However, he was uncertain which particle he ought to use 
and ended up uttering both particle $\boldsymbol{g a}$ and $\boldsymbol{n i}$. Considering the fact that both are

indispensable particles for assembling sentences with benefactive verbs, he knew one of

them was correct, but he was not confident about which to use. It is important to note

here that the need to choose the right particle for the nouns associated with benefactive

verbs contributes to the complexity of these verbs for learners.

In addition to the foregoing examples of errors that the participants made in the

interviews (incorrect benefactive verbs, incorrect form before the benefactive verbs, and

incorrect particles), learners showed confusion due to the complexity benefactive verbs.

Before this excerpt, I asked Daniel who he appreciates the most and he started to explain

that he appreciates his parents.

[Excerpt 12: Daniel]

(1) Daniel:えー...まあ、いろいろな人がいます。

Ee...maa, iroiro na hito ga imasu.

ま、特に両親に感謝の感じがあります。

Ma, toku ni ryooshin ni kansha no kanji ga arimasu.

えつと、もちろん、両親が子供の時から、

Etto, mochiron, ryooshin ga kodomo no toki kara,

えーと、そだ...育てたでしょ。

Eeto, soda... sodateta desho.

それに、わたしの問題に聞いて、

Sore ni, watashi no mondai ni kiite, 
えーと ...うん、え、うん、よく

Eeto... un, e, un, yoku...

(7)

せいじ、あ、もらい?もらいました？あげました？

Seiji, a, morai? Moraimashita? Agemashita?

(8) Takizawa:せいじ?

Seiji?

(9) Daniel: せいじ、くれました?

Seiji, kuremashita?

(10) Takizawa:せいじは何ですか?

Seiji wa nan desu ka?

守ると、育てるの...あ、せわ！世話しました！

Mamoru to, sodateru no... a, sewa! Sewa shimashita!

世話をくれて、えーと、まあ、いい人と思います。

Sewa o kurete, eeto, maa, ii hito to omoimasu.

[English Translation]

(1) Daniel: Umm, well, there are many people.

Well, especially, I have appreciation towards my parents.

Well, of course, since I was a child, my parents

Umm, rai...raised me, you know.

Moreover, they listen to my problem and,

Umm...um, well, um, often...

(8) Takizawa: Seiji?

(9) Daniel: Gave (kuremashita) seiji?

(10) Takizawa: What is seiji?

(11) Daniel: To protect and raise...oh! Sewa! (care) They took care of me!

Give (kuremashita) care of me and well, I think they are good people.

In line (7), he says moraimashita and agemashita with a rising intonation, asking himself

and the interviewer which is the right verb to use. I displayed my confusion in line (8) 
saying seiji? He realized that there was miscommunication between him and the interviewer and said Seiji kuremashita? in line (9). Within line (7) and (9), he supposed the miscommunication occurred because of his incorrect usage of benefactive verbs and tried listing different benefactive verbs. However, the miscommunication was rather due to the word seiji ('government,' which didn't make sense in this context). In spite of his attempting to use moraimashita, agemashita and kuremashita, I still did not apprehend what he intended to say and asked him what he had meant by seiji in line (10). I sensed that seiji was not the word he wanted here since it would not fit in this context. In line (11), he tried to explain what he meant by seiji, describing the definition, and finally recalling the correct word, sewa 'care.' In line (12), he corrected himself, sewa o kurete '(they) give care,' where it would have been ideal to say, sewa o shite kurete with the verb gerund of suru 'do.' This excerpt constitutes one example of a learner's awareness of the complexity of benefactive verbs.

This section examined the misuse of benefactive verbs observed in the interviews. In sum, the present data show that learners of Japanese do misuse the benefactive verbs. The errors that they made include overgeneralization of ageru (using ageru instead of kureru), using an incorrect verb form (not gerund) in combination with 
benefactive verbs, and using incorrect particles. 


\section{CHAPTER 4:}

\section{DISCUSSION}

The previous chapter analyzed the transcription of the interviews and explored the research questions. These are the results thus far:

(1) Do learners use benefactive verbs?

Yes, they do use, (or attempt to use) benefactive verbs to show their benefactive stance. Yet, difficulties that learners face also emerged, especially in utilizing multiple stance indicators in the same context and generating the expressions accurately and automatically.

(2) Do they fail to use benefactive verbs?

Yes, the current data show that learners also fail to use benefactive verbs in contexts where they are called for. At the same time, other strategies for stance-taking emerged such as using evaluative adjectives, adverbs, ritual expressions, and potential expressions.

(3) Do they misuse benefactive verbs?

Yes, they do misuse benefactive verbs. The common errors are: overgeneralizing ageru, using incorrect verb forms before benefactive verbs, and using incorrect particles associated with the benefactive verbs.

In this chapter, based on the results born out, I will explore the following 
questions.

(1) Are there any generalizations to be made about the usage of these stance indicators?

(2) How do learners see benefactive verbs? Do they see as stance indicators?

(3) What are pedagogical implications based on the current research?

\subsection{Are there any generalizations to be made about the usage of these stance}

\section{indicators?}

As analyzed in the last chapter, learners are inclined to fail to use benefactive verbs, but they attempt to take a stance using different stance indicators, especially utilizing evaluative adjectives or adverbs. As a Japanese speaker, I experienced moments when I felt that participants overused evaluative words during the interview.

The following is the excerpt from the interview with Meg. I asked who her favorite teacher is and she answered Ms. Honda, who is a lecturer at her university. I asked why she likes her and she started to describe her personality and her work ethic, answering she is smart, kind and a hard-worker.

[Excerpt 13: Meg]

(1) Meg: えっと、やさしく、頭がいいって、 Eetto, yasashiku, atama ga ii tte, 


$$
\begin{aligned}
& \text { 日本語を教えることを一生懸命します。 } \\
& \text { Nihon go o oshieru koto o isshookenmee shimasu. }
\end{aligned}
$$

[English Translation]

(1) Meg: Well, (she) is kind, smart and,

(2) works hard on teaching Japanese.

As shown in the excerpt above, to answer why she likes her teacher, Meg only evaluated her teacher's personality and her work ethic. In line (2), she could have said Nihongo o isshookenmee oshiete kuremasu 'works hard on teaching Japanese for us' to clarify her interpersonal stance towards the teacher. However, she did not use benefactive verbs; rather she focused on an evaluation of the teacher's work.

Another example is from the interview with Lisa. The following excerpt

occurred when she was explaining why she liked her teacher in elementary school. She explained that she liked the teacher because of his teaching approach and a song he sang in class that was weird.

[Excerpt 14: Lisa]

(1) Takizawa: なんでその先生が一番好きですか?

Nande sono sensei ga suki desu ka?

(2) Lisa: あの、変な教え方を使いました。 Ano, hen na oshiekata o tsukaimashita.

$$
\text { とても変でした。@@ }
$$

Totemo hen deshita.

$$
\text { あの、ある日、授業の全部は歌いました。 }
$$


Ano, aru hi jugyoo no zenbu wa utaimashita.

とても変な歌でした。

Totemo hen na uta deshita.

(6)

いい歌じゃなかったです。@@

Ii uta ja nakatta desu.

[English translation]

(1) Takizawa: Why do you like the teacher the most?

(2) Lisa: Um, (he) used a weird way of teaching. It was very weird. Hahaha.

Um, one day, (he) sang the whole time during class.

It was a very weird song.

It was not a good song. Hahaha.

In line (2), (3), and (5), Lisa used hen 'weird' to evaluate her teacher's teaching approach and his song. Also, she evaluated the teacher's song again by commenting ii uta ja nakatta 'it was not a good song.' As I mentioned in the first chapter, evaluative adjectives such as 'weird,' or 'not good' are categorized as evaluations are also stance indicators. However, they do not make it clear that one is being respectful and being thankful to the person. Since Lisa only evaluated her teacher's teaching approach and his song as hen 'weird' or ii uta janakatta 'was not a good song,' the reason why she likes the teacher is not really clear. If she had said hen na uta o utatte kuremashita 'he sang a wired song for us,' it would have been somewhat clearer that song affected Lisa positively and she appreciates him for it, which could have implied that that is why she liked the teacher. 
The following is another example of how a learner overused evaluation for

stance-taking. I asked Eric if there is any person who took care of him when he was

traveling. He started to talk about his tour guide when he went to Israel with his

grandmother. He described the tour guide using evaluative words.

[Excerpt15: Eric]

(1) Eric: あ、観光の案内の人、えつと、と会いました。

A, kankoo no annai no hito, etto, to aimashita.

えっと、う一ん、おもしろい人物だと思いました。

Etto, uun, omoshiroi jinbutsu da to omoimashita.

(3) Takizawa: ふーん、どうしてですか?

Fuun, dooshite desu ka?

(4) Eric: えっとー、うーん、いつも、えつとー、ちょっとうるさい、 Ettoo, uun, itsumo ettoo, chotto urusai,

けど、うーん...うるさいし、えつと、えー、運転がすごく悪いし、 kedo, unn...urusai shi, etto, eee, unten ga sugoku warui shi,

それでも、えつと、優しい人でした。

Sore de mo, etto, yasashii hito deshita.

(7) Takizawa: え、例えば、どんなことで優しいと思いましたか?

E, tatoeba, donna koto de yasashii to omoimashita ka?

(8) Eric: おばあちやんと、えつと、あ、旅行、する、したんですが、 Obaachan to, etto, a, ryokoo suru, shita n desu ga,

えっと、その人はいつもおばあちゃんに優しかったんです。 Etto, sono hito wa itsu mo obaachan ni yasashikatta $n$ desu.

[English translation]

(1) Eric: Um, we met a tour guide.

Um, I thought he is a funny person. 
(3) Takizawa: Hmm, why?

(4) Eric: $\quad$ Well, umm, always a bit loud But, Umm... loud and well, umm, bad at driving

(7) Takizawa: Well, what kind of things made you think he was kind for instance?

(8) Eric: I travel, ah, traveled with my grandma, but, You know, that person always kind to her.

Eric evaluated the tour guide using a number of evaluative words: omoshiroi 'funny,' urusai 'loud,' unten ga warui, 'bat at driving,' and yasashii 'kind.' Although the interviewer tried to elicit what the tour guide did for him in line (7) by asking for a specific reason, he continued to evaluate the driver's actions, saying yasashii 'kind.' While I conducted the interviews, I realized that the participants tend to evaluate the referents or their actions by using evaluative words but fail to describe what the referents did for them, which would have revealed some interpersonal stance between the speaker and the referent.

Furthermore, some subjects commented that their patents are "good parents" or "good people" during the interviews. For example, John commented his parents are ii oya 'good parents' in the excerpt [6], line (4) when he was talking about his birthday when he was a child. Daniel, also evaluated his parents positively in the excerpt [12], line (12), saying he thinks they are ii hito 'good people.' Another example is from the interview with Kelly when she was asked who she thinks the most generous person around her is. 
[Excerpt 16: Kelly]

(1) Kelly: うーん...難しい。 Unn...muzukashii.

$$
\text { でも、私の母はすごく優しい人と思います。 }
$$

Demo, watashi no haha wa sugoku yasashii hito to omoimasu.

[English translation]

(1) Kelly: Hmm... it is hard.

(2) But, I think my mother is a very kind person.

She described her mother as 'a very kind person,' which is a positive evaluation of her own mother. However, this kind of comment sounds infelicitous to native speakers of

Japanese because it is not common to speak highly of one's in-group members, especially family members, in public. Speakers may talk about what their parents did for them. But this is not the same as giving a positive evaluation of one's parents in public, which might sound arrogant. The participants in this study had clearly learned that being humble is important in Japanese culture (for example, avoiding or rejecting compliments on their Japanese ability) in classroom. Yet they are not fully aware that part of humility in Japan is to avoid evaluating one's own family members highly to outsiders.

\subsection{Learners' view of benefactive verbs}

In this section, I explore a benefactive stance from the learner's perspective. In 
the post-interviews, I asked the participants the following questions in English:

(1) What kind of feeling, or stance do you think you can show by using expressions with benefactive verbs?

(2) When do you think you need to use expressions with benefactive verbs?

(3) Do you consider these expressions difficult?

(4) Do you feel comfortable using them?

For the first two question (1) and (2), in fact, all participants answered that a speaker can acknowledge their indebtedness, appreciation, thankfulness, or gratitude by using expressions with benefactive verbs. However, some learners mentioned that benefactive verbs are used to only emphasize thankfulness rather than they are an indispensable element. Kelly commented, "In a normal conversation, I do not use it, like when I am talking with friends. I use it when I received something meaningful.” Daniel's response was somewhat similar: "They are used when you ask a favor. So if a teacher taught you something, I do not feel obligated to use them, since it is their job. They are used for an emotional moment, not used for small things. I think they emphasize they did something for you." As these comments show, some learners believe that benefactive verbs are used only when a speaker benefitted in a meaningful way or when s/he asked a 
favor, or when the speaker wants to emphasize their gratitude. These assumptions can be the source of miscommunication or misunderstanding because the learners then fail to take a benefactive stance when it is ideal to do so.

In reply to questions (3) and (4), eight participants answered that they consider that expressions with benefactive verbs are difficult and they do not feel comfortable using the expressions. Only two of the participants answered that they found the expressions simple and easy to control.

Kelly who finds them difficult, commented, "The structure itself is difficult. I do not feel like using it correctly and I forget to use it." Steve also answered that they are difficult and commented, "When I speak Japanese, I get nervous and tried to finish quickly and forget to use it." Lisa, mentioned that she understands the concept, but considers that it is hard to produce them automatically: "They are difficult because there are just so many verbs. And in the moment, when I am speaking in Japanese, I am thinking about what I am trying to say, and need to think about which [benefactive] verbs to add, too." Eight out of ten participants answered that they consider expressions with benefactive verbs to be difficult to manage and they end up forgetting to use them or avoiding them altogether. 
On the other hand, two learners, Brian and Alex, consider that the expressions are not really difficult and feel comfortable using them. Brian, who self-studied benefactive verbs in Japan commented, "It is not really difficult. At first, it took a little bit of thinking, but once I figured it out, it just sort of became my vernacular. ” Alex, who studied the expressions in a summer intensive course at Portland State and went to Japan right after the summer course said, "At first, it was really hard, and then it just clicked. At one point, something clicked. Maybe because I heard them a lot in Japan.”

What they have in common is that it took some time to understand the concept at first, but they had a moment that 'it clicked' or they 'figured it out' and came to have better control over them. In addition to it, they were both living in Japan and immersing themselves in a Japanese speaking environment when they were acquiring the expressions. As Pizziconi (2000) says, benefactive verbs "suggest a strong relevance of the language-specific, culture-based conventional conceptualization that they index, i.e. the notion of benefit that can develop in natural interaction" (p. 383). It can be considered that the development of the notion of "benefit" may be related to how much the learners interact with Japanese native speakers; however, the number of subjects is too limited and I do not posit any assumptions here. 


\subsection{Pedagogical implication}

In this section, I would like to examine ways to promote learners' awareness of

benefactive stance in Japanese culture.

\subsubsection{Can we operationalize the notion of benefactive stance for the classroom?}

To gain some sense of how the expressions with benefactive verbs are being taught in Japanese language classroom, I would like to explore they are introduced in JFL textbooks. Here are some examples of how JFL textbooks introduce [verb gerund + benefactive verbs]:

(1) We have long been familiar with the request patterns/gerund + kudasai/ and /gerund + kudasaimasen ka/, which request the 'giving' of actualized action represented by the verbal. We now extend those patterns to include not only all forms of kudasaru, but also all forms of the other four verbals of giving.

In general terms, /verbal gerund X + verbal of giving/ = 'performance of $\mathrm{X}$ for the benefit of someone.' The performer of the activity, if expressed, is followed by $g a$ (or wa) and the benefactor (the person 'to whom' the action is given) by particle $n i$. [Example sentences]. The verbal of giving may, of course, occur in a negative derivative form: [Example sentences] or, in the cases of yaru, ageru, and sasiageru, it can appear in a tai- derivative form: [Example sentences]. The accentuation of this pattern is parallel to that of /gerund $+o k u /$ and /gerund + simau/.

The frequency of the pattern using verbal of giving cannot be overestimated. Probably the greatest difficulty it poses for the foreign students is simply to remember to use it. It often occurs in Japanese when the English equivalent contains nothing parallel $-\mathrm{a}$ further reminder that Japanese is not a translation of 
English! Consider these Examples: [Example sentences]. In the both cases, Japanese overtly indicates the relationship of the speaker to the action as that of benefactor, and assigns directionality to the activity.

(Japanese: The Spoken Language [JSL] Part 2 pp.113-114)

(2) We learned in Lesson 14 that the verbs kureru, ageru, and morau describe transaction of things. Here we will learn the use of these words as helping verbs. When these [giving and receiving] verbs follow the te-form of a verb, they describe the giving and receiving of service.

Te-form+ageru: I do something for you.

You do something for others.

I do something for others.

Somebody does something for somebody else.

Te-form+kureru: Somebody does something for me.

You do something for me.

Somebody does something for you.

We use the te-form + ageru when we do something for the sake of others, or somebody does something for somebody else. The addition of the helping verb ageru does not change the basic meaning of sentences, but puts focus on the fact that the actions were performed "on demand" or "as a favor." [Example sentences] We use kureru when somebody does something for us. [Example sentences] We use the $t e$-form + morau to say that we get, persuade, or arrange for, somebody to do something for us. In other words, we "receive" somebody's favor. The person performing the action for us is accompanied by the particle $n i$. [Example sentences] Compare the last sentence with the kureru version below. They describe more or less the same event, but the subject are different. In morau sentences, the subject is the beneficiary. In kureru sentences, the subject is the benefactor.

(Genki 2 pp.74-75)

(3) In Japanese, an action that is done for the benefit of someone else can be 
expressed by using the te-form with the verbs of giving and receiving. Like kureru and kudasaru, the recipient of the te-form of the verb + kureru/kudasaru is the speaker or a member of the speaker's in-group. The giver can be anyone but the speaker. Kudasaru is used when the giver is an out-group person who is socially superior to the speaker.

The in-group/out-group distinction can be applied in social context other than family. For example, the members of the speaker's company comprise an in-group in contrast with those who do not belong to that company. In this case, use kudasaru when a customer, who is regarded as social superior to company members in a business context, does something for any member of the company, including the speaker's boss, or even the company president (who would be considered the speaker's superior in a strictly in-company relationship).[Example sentence]

The $t e$-form of the verb + kudasai and the te-form of the verb + kureru/kudasaru are derived from this structure.

The recipient of a favor need not be overtly marked when it is obvious. [Example sentence]

(Nakama 2 pp. 389-390)

$J S L$ and Nakama explain these verbs using the word, "benefit" which indicates that the subject gains something from others when the expressions are used. On the other hand, Genki, mainly gives translations of each expression such as "somebody did something for us" for [verbs gerund + kureru].

$J S L$ is the only textbook that emphasizes the frequency of the occurrence of the expressions in Japanese conversation, and also explains that the challenge for learners is 
to remember to use them. This is a good reminder to learners that they should expect to hear (and use) these expressions; learners should be aware and monitor their own and native speakers' use of these expressions. What is unique about Nakama is that it mentions how the uchi-soto distinction can change depends on the situation by offering an example of a business setting and how the distinction and the context affect the use of benefactive verbs.

Overall, JFL textbooks explain the expressions as giving and receiving an action/performance/service, yet do not talk about what kind of stance or feeling a speaker can express by using them. It is hard to find anything in these explanations that could be interpreted as related to an interpersonal stance, such as showing appreciation, gratitude, or being thankful to the giver. I consider that these explanations are not sufficient for learners to fully understand what kind of stance and feeling one can index by using these expressions and why they are frequently used in Japanese language.

How can we operationalize the theoretical construct of stance such that it is applicable in teaching? I suggest that textbooks might make better use of what are called "keywords" in conveying to learners the significance of elements such as benefactive verbs. 


\subsubsection{Keywords}

Keywords are a theoretical construct that is readily turned into something that learners can understand. In Keywords: A Vocabulary of Culture and Society, Williams (1976) lists and explains keywords in American culture such as Capitalism, Civilization, Democracy, Liberal, etc. He regards keywords as vocabulary items that bound practices and ideas together in a culture and society: "I call [these] Keywords in two connected senses: they are significant, binding words in certain activities and their interpretation; they are significant, indicative words in certain forms of thought. Certain uses bound together certain ways of seeing culture and society, not least in these two most general words" (p. 13).

In Understanding Culture through Key Words," Wierzbicka (1997) explores

keywords in different cultures, including English, Russian, Polish, German, and Japanese, to elucidate the important concepts of each culture. She emphasizes that there are certain words that are particularly important to the culture and learning those keywords helps us to understand the cultural values and mores: "a key words such as enryo (roughly 'interpersonal restraint'), on (roughly 'debt of gratitude') and omoiyari (roughly 'benefactive empathy') in Japanese can lead us to the center of a whole complex of 
cultural values and attitudes, expressed, inter alia, in common conversational routines and revealing a whole network of-culture-specific 'cultural scripts'” (p. 17).

In more recent work, Ghaziani and Ventresca (2005) explore how economic keywords have changed over a 25 year period and how the keywords capture cultural change over a period of time in the society. They argue that keywords are produced and used in a specific area or a period of time in a certain society, yet the meaning is common enough that notions can be shared globally: "there is a tension between producing a keyword that is at once specific to local contexts while remaining general enough to engage a collective, global audience" (p. 525).

What Williams, Wierzbicka, and Ghaziani and Ventresca have in common is that keywords are items of vocabulary that express central concepts of a certain culture or society; they can be a tool to share the core concept of the culture. In other words, keywords literally can be a "key" for us to unlock an intricate cultural value or social structure.

Wierzbicka lists Japanese keywords including amae 'dependence,' enryo 'restraint,' wa 'harmony,' on 'obligation,' giri 'duty,' seishin 'spirit' and omoiyari 'empathy.' These keywords are fundamental notions that Japanese people share; they can 
be keys for learners to understand Japanese cultural value. It is also important to note that some of these keywords closely relate to the acts of giving and receiving. Let us see an example of omoiyari 'empathy,' on 'obligation', and giri 'duty' and how the keywords embrace the concept of giving and receiving. In Wierzbicka's book, she breaks down on as follows:
(a) X thinks about someone:
(b) this person did something good for me.
(c) I couldn't do something like this for this person
(d) I have to think about this always
(e) I have to do good things for this person because of this
(f) if this person wants me to do something I have to do it.
(g) X feels something bad because of this

(Understanding Culture through Key Words p. 279)

As shown above, the keyword, on, is clearly related to the concept of giving and

receiving. Someone does something good for $\mathrm{X}$, and $\mathrm{X}$ feels obligated to give something good back to the giver.

Giri 'duty', also concerns the idea of giving and receiving. Wierzbicka

formulates giri as follows:

(a) $\mathrm{X}$ thinks something like this about someone:

(b) I have to do good things for person $\mathbf{Y}$

(c) if I don't do this it will be bad

(d) if I don't do this, Y can feel something bad

(e) people will say bad things about me because of this

(f) I don't want this

(g) because of this, I have to do good things for $\mathbf{Y}$ 
(h) I have to think about this

(Understanding Culture through Key Words p. 280)

Another keyword is omoiyari. Wierzbicka portrays omoiyari as follows:

(a) X thinks someone like this:

(b) I think I can know what this person feels

(c) I think I can know what this person wants

(d) I can do something good for this person because of this

(e) I want to do this

(f) this person doesn't have to say anything

(g) because of this, $X$ does something

(h) people think: this is good

(Understanding Culture through Key Words p. 280)

Based on the formula, omoiyari, also embraces the concept of giving and receiving,

which described in line (d). Briefly, X perceives other's want and X wants to do

something good for this person. And, it is perceived as good in the society.

If on, giri and omoiyari are important in Japanese society, it is also important

that we recognize a speaker's awareness of these concepts through language use. And

expressions with benefactive verbs are fundamental devices to mark speaker's feeling of

on and giri, as well as omoiyari.

When a new expression is introduced in class, especially benefactive verbs, the

focus usually is on a grammatical explanation (due perhaps to their complexity). As a

result, learner attention focuses on the grammar rather than the cultural aspects of the 
expressions. Especially because there are no equivalent expressions in their own language system, I claim that learners should be encouraged to understand the whole concept of benefaction in Japanese. This includes: what these verbs mean, when they are used (usage in a situated context), how they are used (grammatical patterns), and why they are used (understanding why the expressions are used in the culture). I suggest that introducing them by integrating with keywords can be effective.

In fact, Alex, who has the best proficiency of benefactive verbs mentioned some keywords in Japanese culture during the post-interview. He commented as follows: "They [Japanese] really hold close, um, kind of like, kindness, ongaeshi ['reciprocation'] or omoiyari ['empathy'], like give something and give them back something, like that kind of relationship. Giving and receiving is very important in Japanese culture and that is why we have those kinds of expressions." I would like to emphasize two facts: Alex understands an important concept of Japanese culture and he has good control over the expressions. This is not coincidental. He is aware of the concept and his awareness is related to his proficiency in the expressions. As Pizziconi (2000) states, "successful acquisition of a language entails an understanding of the cultural values and (salient) attitudes to those values in a linguistic 
community." Through keywords, learners have an entry to understanding benefaction and they help learners to understand why the use of benefactive verbs is important in Japanese culture, and regards them as indispensable stance-indicators in Japanese. Integrating keywords into our pedagogical analysis of benefactive verbs will improve learners' awareness of the importance of benefaction and promote their use of the expressions. 


\section{CHAPTER 5:}

\section{CONCLUSION}

In the first chapter, I defined stance as "an act taken by a speaker or a writer to

show his/her attitude, personal evaluation, and/or feelings towards the entities or person within the social context." The role of stance-taking is to show one's attitude, evaluation, feeling in a social context and it always involves the referent, the interlocutor, and the audience. Successful stance-taking always invloves cultural coherence. Therefore, learners of a foreign language should be aware of the way in which native speakers of the target language take a stance and what kind of grammatical devices, or stance indicators can be marshaled for stance-taking.

Benefactive verbs are indispensable stance indicators in Japanese to show

gratitude. However, since the grammar is extremely complex and there are no equivalent expressions in English, I assumed that learners are not able to manage the use of expressions and are not able to take a benefactive stance.

By analyzing the transcription of data collected from JFL learners via narrative interviews, the following hypotheses were born out: (1) learners do use (or attempt to use) benefactive verbs to indicate stance, (2) they also fail to use benefactive verbs in 
contexts where they are called for, and (3) they misuse benefactive verbs. Furthermore, the transcription showed that even when learners fail to use benefactive verbs, they still attempt to take a stance using strategies other than benefactive verbs, such as evaluative adjectives, adverbs, potential expressions, or ritual expressions that show appreciation. Nevertheless, it is important to note that these strategies do not display their interpersonal stance of benefaction between the speaker and the referent in a culturally coherent way. The post-interviews revealed learners' awareness of benefactive verbs. In fact, all subjects were aware that expressions with benefactive verbs can index the speaker's appreciation and indebtedness, yet most of them find the expressions difficult and are not confident managing them. Moreover, some learners did not have a full understanding of when the expressions are used and they did not regard the expressions as indispensable stance-taking indicators. This kind of underestimation and misunderstanding surely affects their usage of benefactive verbs and can account for their failure to use or misuse the expressions.

The data and post-interviews showed how difficult the expressions are for JFL learners and there are a number of difficulties that learners are facing for the acquisition of the expressions, such as the understanding the grammar, when to use them, remember 
to use them in a conversation, and using them automatically and correctly. To promote learners' awareness towards the benefactive stance shown by the expressions with benefactive verbs, I claim that introducing keywords into classroom can be effective. Keywords such as omoiyari, on, and giri are one of the most important concepts that people share in Japanese culture. I believe that introducing those keywords with benefactive verbs in classroom will help learners to understand the core concept of Japanese culture and how they are related to a benefactive stance.

This study examined ten learner's stance-taking in Japanese focusing on how they take a benefactive stance. However, in order to gain more understanding of learners' disposition toward stance-taking, data from a larger number of learners are needed. A better understanding of how Japanese native speakers take a benefactive stance would also allow us to 1. compare how learners' stance-taking differs from native speakers' and 2. search for effective ways to train learners in stance-taking. Questions for future study include: (1) How do Japanese native speakers take a benefactive stance? Benefactive verbs are only one vehicle for stance-taking in Japanese. What are others and how do they interact with the verbs examined here? (2) What features of context call out benefactive verbs? Is their use somehow predicatable in a way that will allow us to train 
learners in their use? (3) How can we help learners develop stance-taking via benefactive verbs in Japanese? (4) Finally, what other sorts of stances —e.g., regret, support, dependence, etc. —are taken by native speakers and how could training be beneficial to learners?

Despite the limitations of this study, it contributes to the investigation of learners' stance-taking. Central to all of this are keywords that will help learners to understand the importance stance-taking in Japanese culture. It is critical to understand cultural values in the target language for a successful acquisition of any foreign language. By integrating keywords such as on, giri, and omoiyari into the expressions with benefactive verbs in the classroom, learners will be more aware of the importance of showing stance in Japanese culture and will be able to view the expressions as fundamental devices for integrating into Japanese culture. 


\section{REFERENCES}

Banno, E., Ohno, Y., Sakane, Y., Shinagawa, C., \& Takashiki, K. (1999). Genki: An integrated course in elementary Japanese (Vol. 2). Tokyo: The Japan Times.

Biber, D., \& Finegan, E. (1989). Styles of stance in English: Lexical and grammatical marking of evidentiality and affect. Text-Interdisciplinary Journal for the Study of Discourse, 9 (1), 93-124.

Cambridge Academic Content Dictionary (2008). Retrieved from https://dictionary.cambridge.org/us/dictionary/english/stance

Du Bois, J. W. (2007). The stance triangle. In R. Englebretson (Ed.), Stancetaking in discourse: Subjectivity, evaluation, interaction (pp.139-182). Amsterdam: John Benjamins Publishing.

Englebretson, R. (2007). Stancetaking in discourse: Introduction. In R. Englebretson (Ed.), Stancetaking in discourse: Subjectivity, evaluation, interaction (pp.1-26). Amsterdam: John Benjamins Publishing. 
Ghaziani, A., \& Ventresca, M. J. (2005). Keywords and cultural change: Frame analysis of business model public talk, 1975-2000. Sociological Forum, 20, 523-559.

Hatasa, Y. A., Hatasa, K., \& Makino, S. (2010). Nakama 2: Japanese communication, culture, context. Scarborough: Nelson Education.

Hunston, S., \& Thompson, G. (2000). Evaluation in text: Authorial stance and the construction of discourse: Authorial stance and the construction of discourse. New York, NY: Oxford University Press.

Ide, R. (2016). スタンスの日米比較 [Comparison of stance between Japan and U.S. ] Journal of International and Advanced Japanese Studies, 8, 1-16.

Jaffe, A. (2009). Stance: Sociolinguistic perspectives. New York, NY: Oxford University Press.

Jorden, E. H., \& Noda, M. (1987). Japanese, the spoken language: Part 2. New Haven, CT: Yale University Press. 
Kiesling, S. F. (2009). Style as stance: Stance as the Explanation for Patterns of sociolinguistic Variation. In A. Jaffe (Ed.), Stance: Sociolinguistic perspectives (pp.171-194). New York, NY: Oxford University Press.

Kormos, J. (1999). Monitoring and self-repair in L2. Language Learning, 49 (2), 303342.

Labov, W. (1972). Sociolinguistic patterns. Philadelphia, PA: University of Pennsylvania Press.

Maynard, S. K. (1997). Japanese communication: Language and thought in context. Honolulu, HI: University of Hawaii Press.

Nakane, C. (1970). Japanese society. Berkeley, CA: University of California Press.

Palmer, F. R. (1986). Mood and modality. New York, NY: Cambridge University Press.

Pizziconi, B (2000). Some remarks of the notion of 'benefit' and the Japanese communicative style. SOAS Working Papers in Linguistics, 10, 371-384.

Pizziconi, B. (2006). Learning to reframe: Japanese benefactives, metalinguistic beliefs and the identities of L2 users. In A.Yoshitomi, T. Umino \& M. Negishi (Eds.), 
Readings in second language pedagogy and second language acquisition: In Japanese context (pp.119-154). Amsterdam: John Benjamins Publishing.

Wetzel, P. J. (1985). In-group/out-group deixis: Situational variation in the verbs of giving and receiving in Japanese. In J. P. Forgas (Ed.), Language and social situations (pp.141-157). New York, NY: Springer.

Wetzel, P. J. (2004). Keigo in modern Japan: Polite language from Meiji to the present. Honolulu, HI: University of Hawaii Press.

White, P. R. (2003). Beyond modality and hedging: A dialogic view of the language of intersubjective stance. Text-Interdisciplinary Journal for the Study of Discourse, 23 (2), 259-284.

Wierzbicka, A. (1997). Understanding cultures through their key words: English, Russian, Polish, German, and Japanese (Vol. 8). New York, NY: Oxford University Press.

Williams, R. (2014). Keywords: A vocabulary of culture and society. New York, NY: Oxford University Press. 


\title{
APPENDIX A: INFORMED CONSENT FORM
}

\author{
Analysis of JFL leaners' narratives
}

You are invited to participate in a research study conducted by Kumiko Takizawa from Portland State University, the department of World Languages and Literature. The goal of the study is to find how learners of Japanese tell narratives in Japanese. In particular, the researcher hopes to explore learners' language use when they are talking during narrative interviews. This study is being conducted in partial fulfillment of the requirements for a masters' degree program, under the supervision of Dr. Patricia Wetzel of Department of World Languages and Literatures at Portland State University.

You were selected as a possible participant in this study because you are a learner of Japanese who is enrolled in 300/400 level Japanese class. If you decide to participate, you will be asked 6 questions by the researcher. You will answer questions in Japanese based on your own experience or memories. No preparation is required. The interview will be voice-recorded. Recording starts from the moment the researcher ask the first question until you leave the room, using audio recorder [Olympus Digital Voice Recorder]. The estimated length of time for the interview is 30 minutes. After answering questions, you will provided with feedback on your grammar usages if you wish. After the interview, the researcher might ask you to come back to ask follow-up questions in English to explore more of your Japanese use in the interview. The risk of participating this study might include being audio-recorded can be uncomfortable, being concerned that you may make mistakes in Japanese. Remember that there is no right or wrong answer. It is important that you take part in the interview as naturally as possible.

Any information that is obtained through this interview and including your information or people's name you are referring will be kept confidential. The information you give me will be kept confidential to the extent permitted by law. Copies of the recordings, the transcriptions, and the consent forms will be kept in a secure locker in one of the private office at PSU. . When I report the findings of the study, I will use pseudonyms for any personal names. Your participation is voluntary. You do not have to take part in this study, and it will not affect your academic grade or your relationship with Portland State University or the researcher. You may also withdraw from this study at any time without any penalty or negative consequences. 
If you have questions or concerns about your participation in this study, contact Kumiko Takizawa at kumiko@pdx.edu or visit her office at Neuberger Hall M237B. If you have concerns about your rights as a research subject, please contact The PSU Office of Research Integrity, 1600 SW 4th Ave., Market Center Building, Ste. 620, Portland, OR

97201; phone (503) 725-2227 or 1 (877) 480-4400; email hsrrc@pdx.edu.

Your signature indicates that you have read and understand the above information and agree to take part in this study. The researcher should provide you a copy of this form for your own records.

Printed Name

Signature

Date 


\section{APPENDIX B: INTERVIEW QUESTIONS}

(1) Who is your favorite teacher? Why? 好きな先生は誰ですか。なぜですか。

(2) What's the best birthday you ever had? Why? 一番よかった誕生日の思い出は何 ですか。どうしてですか。

(3) Have you been taken care of by anyone when you were studying abroad or when you were traveling? Please share your memory. 留学中や旅行中に誰かにお世話になった たことはありますか。思い出を教えてください。

(4) Who is the most generous person you know? Why do you think so? 知っている人の 中で、誰が一番親切だと思いますか。どうしてそう思いますか。

(5) When you face difficulties in your life, who do/ did you consult with? Why do/did you consult with this person? 人生で大変なことがあったとき、誰に相談します か。または、しましたか。どうしてこその人に相談しますか。

(6) Who do you appreciate in your life? Please share your memory of a time when you felt appreciation/gratitude towards someone. 人生で、感謝している人は誰ですか。 その人に、感謝を感じたときの思い出を教えてください。 


\section{APPENDIX C: POST-INTERVIEW QUESTIONS}

(1) What kind of feeling or stance can you project by using benefactive verbs?

(2)When do you think you are supposed to use the expression?

(3) Do you consider these expressions difficult?

(4) Do you feel comfortable using them? 


\section{APPENDIX D: INSTRUCTION FOR THE CHECKER}

Read the transcription of each interview and highlight that sentences that giving and receiving expressions are

(1) used (correctly or incorrectly)

(2) missing

(3) misused

Giving and receiving expression includes kureru, morau, and ageru as well as their honorific/humble equivalent, kudasaru, itadaku, sashiageru. After you highlight them, provide the verbs that you think are missing for (2) and the correct verbs for (3). Mistakes include particles that are related to the benefactive verbs and the form of gerund (teform).

トランスクリプションを読んで、以下の箇所をハイライトをしてください。授受 表現が

(1) 使われている(間違えを含む)

(2) 欠如している

(3) 間違っている

授受表現は、くれる、もらう、あげる、また、その尊敬、謙譲表現のくださる、 いただく、差し上げるを含みます。ハイライトをした後に (2) には何の動詞が 欠如しているのか、(3) には何が正しい表現かを記入してください。(3) の間違 いに関しては、授受動詞に対する助詞の間違え、て形の間違いも含みます。 


\section{APPENDIX E: TRANSCRIPTION CONVERSATIONS}

、 =blief pause in Japanese version

, =bleif pause in the romanized/English version

$\ldots=$ =pause longer than $、$ and, but shorter than 1.5 seconds

[\# sec] =silence that lasts \# seconds

- =failing intonation in Japanese version

. =failing intonation in romanized/English version

? =rising intonation

@ =short laughter

@ @ =longer laghter

Bold $=$ Use of benefactive verbs

$\underline{\text { Underline }}=$ Failure of use benefactive verbs

* =Misuse of benefactive verbs and related grammar -i.e. forms of gerund and particles 


\section{APPENDIX F: TRANSCRIPTIONS OF THE INTERVIWS}

\section{T: Takizawa (Interviewer), M: Subject\#1:Meg}

$\mathrm{T}:$ えーと、出身はどこですか?

M: えーとー、出身は、えーとー、ポートランドに住んでいます。

T: あ、そうですか? ? レーとー、高校はどこに行きましたか?

M: えーとー、PSU の図書館です。

$\mathrm{T}$ : 高校?

$\mathrm{M}:$ こうこう? ?

$\mathrm{T}$ : ハイスクール。

M: あ、そうですね。えー、日本語忘れちやった。本当に、コミュ障があるよ。 @ @

$\mathrm{T}:$ @高校はどこに行きましたか?

$\mathrm{M}:$ タイガードハイスクールです。

T: あ女、そうですか。えーとー、じやあ、どのぐらい日本語を勉強しています か?

M: えーとー、2 年ぐらい勉強しています。

$\mathrm{T}:$ あ、 2 年でこんなに上手になってすごいですね。

M: いえいえいえ。@

$\mathrm{T}$ : 本当にすごいです。どうして日本語、を勉強しようと思ったんですか?

M: えーとー、この前の大学に、えっと、この...Language? えっとは一、中国語 と、アラビックとスパング、スパングと、えっとー...だけですけど、えっとー、 わたし、あと、中国語受けました。でも...中国語の文学がわたしにはちょっとつ まらないと思いますけど、えと一、日本の文学、あ、が大好き、それから、日本 語を勉強しています。

T: なるほど、わかりました。えっと、じゃあ、あの一、いろいろな先生から、勉 強したと思うんですけど、日本語とか中国語とか、何でも。一番好きな先生は誰 ですか?

M: えっと、本田先生です。

T: あ、そうですか。どうしてですか？

M: えっと、やさしく、頭がいいって、且本語を教えることを一生䀣命します。

$\mathrm{T}$ : なるほど。わかりました。じゃあ、次なんですが、誕生日の思い出で、一番 良かった誕生日は?

M: 一番良かったですか? ...えっとー[3sec]えー、この問題、この質問がちょっと 難しいと思う。うーん[6sec]クレーターレイクに、あと、行くっていう、えと、こ う、おお...

T: 思い出?

M: 思い出。

$\mathrm{T}$ : 誕生日だったんですか?

M: うん。 
$\mathrm{T}:$ どうしてそれが一番よかったと思いますか？

M: えっと一、わたしと私の日本人のともだちに行って、えっと一、日本語をえ っと一[2.5 sec]日本語をとっても練習して、えっとー、きれい...きれい...で、広い、 広く lake を見て、えーとー ...もしろい人が、ありました。

T: ああ、そうなんですか。

M: えっとー、カフェで、あの、人は、わたしたちを見て、とちょっと、ないし よ話して、しました。@

T: @ああ、そうですか。その誕生日にどんなことしましたか?

$\mathrm{M}:$ えっとー、[5sec]みず? Lake みて、あー、みました。えーとー...ちょっとー ...まずい食べ物を食べました。えっとー[4.5 sec]帰り、帰るとこは、えっと、私、 運転者だったけど、えっとー、本当に迷いました。@

$\mathrm{T}$ : でも、番良かったですか?

M: でも一番良かった。@

T: ああ、そうですか。@わかりました。じゃあ、次の質問ですが、え一、留学し ているときとか旅行しているときに、誰かにお世話になりましたか?

M: えーとー、[3sec]さよちやんと、えと、ミラー先生、えっとー、とミラー先生 の、えっとー、かぞ、ご家族です。えっと一日本に行ったときは、えとは、さよ ちゃんのおかぞ、ごかぞ、に見て、えと一...それから、え、わたしの友達、るい っていう友達、広島に行って、えと、あとで、東京に帰って、えと、わたしの友 達、なおっていうに、なののお宅に泊まって、えっと一、あとで、ミラー先生の、 えっとー妻の...えっとー[2.5 sec]妹、に、の、え、お宅に泊まって、えっとー、で も舞台のプレゼンテーションがある大阪に。それから、ミラー先生のご家族と私、 電車にのって、それから大阪に行った。

T: じゃあ、例えば、色々、お世話になった人とどんなことをしましたか?

M：えっと一、旅館に泊まった。あ、えっと一、あわびを食べた。よかった。@ おいしかった。

$\mathrm{T}:$ じゃあ、ミラー先生の奥さまの、えーと、妹さん?は、とはどんなことをし ましたか?

M: えっとー、かおりさんの家で、えっと、かおりさんは、日本のおもしろいド キュメンタリー、NHKのドキュメンタリーを私に見させた。@

$\mathrm{T}:$ ふーん、どうでしたか、それは?

M: うーん、えっとー[2sec]わたし、びっくりしたので、えっとー、NHK のドキ ユメンタリーは[2.5sec]ほとんどわかりました。

T: おお、そうですか。おもしろかったですか?

M: うん。この日本語、作った日本語わかりました。

$\mathrm{T}$ : あ、そうですか。日本の人からプレゼントとかありましたか?

M: はい、もちろんです。なおは、シリアルです。えっとーるいは...

$\mathrm{T}:$ あ、ちがくて、日本人からは?

M: あ、すみません。@ありますよ。クリスマスプレゼント、この、Lotion?*が、 えっと、くれました。本当にやさしい。 
T: じゃあ、次の質問ですけど、知っている人の中で、誰が一番親切だと思いま すか?

M: えっと、親切?

$\mathrm{T}$ : generous とか kindっていう意味です。

M: おお、そう。もう一度お願いします。

$\mathrm{T}$ : 知っている人の中で、誰が一番親切だと思いますか?

M：えっとー、かおりさんと思います。かおりさんは、えっと、わたし、あっと 一[1.5sec]ちょっと...日本に行った時の前に、えっとー、かおりさん、えっとー、 一回？あと、あったことある。それから、かおりさん、わたし、ちょっとわかり ませんけど、えっとーまだ、わたしを...えっとー[1.5sec]インバイトします。

T: ふーん、なるほど。今もですか?

M: うん。

$\mathrm{T}$ : やさしい人ですね。なるほど。じゃあ、次のクエスチョンですけど、人生で 大変なことがあったとき

$\mathrm{M}:$ ブラウン先生の授業です。@@

$\mathrm{T}:$ @@例えば、そういう大変なことがあったとき、誰に相談しますか?

M: えっと、たぶん[2.5sec]エリーっていう友達です。本当に運がいいと思います。 えっと、ミッドタームのときにはこのスコールは、99です。

T: あ、その友達がですか?

M: うん。

$\mathrm{T}$ ：その、相談した、もう相談しましたか？

M: うん。

$\mathrm{T}:$ ど、どんなアドバイスでしたか?

M: えーとー[3sec]もうちょっと勉強してくださいって言った。@

$\mathrm{T}$ : @なるほど。それは、あの、役に立ちましたか?そのアドバイス。

M: うん。

T: あ、そう。わかりました。じゃあ、最後のクエスチョンですけど、人生で感 謝している人は誰ですか?

M: 感謝ってどういう意味?

$\mathrm{T}$ : 感謝は appreciation とか gratitude です。

M: あ、そうですか。えーとー[5sec]また、ミラー先生と思います。えーとー、ミ ラー先生は本当に、えーとー私にえーとー ...opportunities *にくださ、く、く、く ださいました。えっと、例えば、日本に行ったこと、授業にうけたことと、レコ メンデーションレター書いたことと、一番のパートを...くださいました。えーと 一、舞台で。

T: ふーん、なるほじね。じやあ、あの、一番感謝を感じたときの思い出はあり ますか?

M: うーん、もう一度お願いします。

$\mathrm{T}$ ：一番感謝を感じたときの思い出はありますか?ミラー先生と。

M: うーん、えーとー[2sec]多分、日本に行った時、えとー、この旅館に泊まった とき、えとー、あわびを食べたあとに思った。@@ 
$\mathrm{T}:$ それは、ミラー先生があのーお金とか全部？

M: えっとー、スナックファンデーションは、あの、ファンデーションは、ご、 旅館の...えっと一...晚御飯を、えっとー[2sec]くれたけど、えっとー、ミラー先生 は私を誘いました。それから、私はあわび、えっと一食べられました。

T: なるほどね。どうでしたか?あわびは？

$\mathrm{M}:$ えっとー、あわびは、えーと[3sec]最初は、えっとー、生き、生きました? Alive。でもわたし、えっとー、見る、見る間にあわびは死んだ。@このホステス は焼きまし、焼けた。

$\mathrm{T}:$ @あ、あわびをね。どうでしたか? 味は?

M: 味は、アワビとバターを食べたけど、えと、おいしかった。

$\mathrm{T}:$ じゃあ、ミラー先生に㱛、気持ちをどうやって伝えましたか?

M: えーと、どうやって [5sec]ぶーん[7sec]えっと、舞台のメイクアップトレーニ ングを私、手伝ってあげた。舞台のコスチュームと、着物とか、袴とか、えっと、 手伝ってあげた...と...舞台について全部手伝ってあげた。@

T: @なるほど。じや、たくさんお手伝いしたんですね。

M: @はい。

T: なるほど。じゃあ、質問は終わりです。ありがとうございました。

M：ありがとうございました。

\section{T: Takizawa (Interviewer), J: Subject\#2: John}

$\mathrm{T}:$ えー、ジョンさん、出身はどこですか?

$\mathrm{J}:$ 出身は、あの、あの、えーミシガン州のデトロイトです。

T: あ、そうですか。ふーん...じゃあ、高校は、デトロイトの高校に行きました か?

J: はい、あの、北、デトロイトの北にあります。北、北ところですよ。

$\mathrm{T}$ : そこで、じやあ、小学校、中学校、高校、ずっと、その学校、デトロイトの学 校ですか?

J: はい、そう、そう。

$\mathrm{T}:$ じゃあ、どのぐらい日本語を勉強してますか?

$\mathrm{J}:$ あ、どのぐらい、あの一今、それで、あ一...女の $\cdots 66$ 年勉強しました。

$\mathrm{T}:$ あ、6 年ですか。最初はどこで勉強しましたか?

$\mathrm{J}$ : 最初?あの一、M 大学、始めました。勉強するのは。

$\mathrm{T}$ ：そうですか。えとー、じやあ、どうして日本語を勉強しようと思たんですか？

$\mathrm{J}:$ 女の[5sec] 7 年前に、あの、小津安二郎の映画を見ま、見たことがありますが、 あの...女一...との映画は東京物語、その映画はちょっ、とてもおもしろいです。 けじ、あの、あの、たくさん日本語で、あの、聞きました。あの、その語は、あ の、おもしろいね。あの、きれいな、きれいな語ですよ。と思いました。

T: ふーん、なるほどね。わかりました。で、日本語を勉強しようと思ったんで すね。

J: あの、それから、日本語で勉強したい。かもしれません。 
$\mathrm{T}$ ：ヘー、じゃあ、あの、色々な先生から勉強したと思うんですけど、一番好き な先生は誰ですか?

$\mathrm{J}:$ んー、あの、失礼ですか?

$\mathrm{T}$ : いえいえ、大丈夫ですよ。私じゃなくても、誰でも。あのほか $\mathrm{M}$ 大学の先生 でも。

$\mathrm{J}$ ：あの、 $\mathrm{M}$ 大学の先生の名前は、あの、山本先生。あの、山本先生、優しいな 先生でした。あの一 ...それに、あの[2.5sec]あ、カタカナとひらがなと、あの...ん 一[5sec]ティーチ[3sec]

T: お、し?

J: @教えました@すみません。少し恥ずかしいです。あの、あの、こんな言葉は、 あの、おはようございますと、行ってきます、行ってらっしやい、など、こんな 言葉を教えました。

$\mathrm{T}$ ：そうですか。じやあ、どうして、山本先生は一番好きだと思いますか？

$\mathrm{J}:$ 山本先生は、あの、毎日、げんけ、元気な先生です、でした。毎日、いつも、 いつも、あの、元気でした。あの、毎日教育は大好きだ、と思いました。

T: なるほじね、会ってみたいですね。じゃあ次なんですけじ、ジョンさんは、 旅行とかしますか?

$\mathrm{J}$ : 旅行?はい。好きです。最後の旅行はテキサス。あの、ウェストテキサス。大 きい空...でした。

T: ああ、建物が低いんですね。へー、じゃあ、そのテキサス旅行しているとき に、誰かにお世話になりましたか?

$\mathrm{J}:$ はい、あの、あの、友達は 3 人友達。旅行行きました。けど...あの[2sec]一人、 一人だけ、あの、う一ん...大嫌いです、でした。あの、みんな、ちょっと、ん、 ちょっと、わかんない、たくさんの酒のみました。@あの、その人は、あの、つ まらないです。あの、行きません。あの、バーで、あの、リンジーさんはバーで 行きましょうか。あの、つまらない、行きません。@ほかの人は...@あの、あの 一、楽しかったです。

T: あ、そうですか。何か、お世話になったところとかありますか？どこに泊ま りましたか?ホテルに泊まりましたか?

$\mathrm{J}:$ うん、あの一[2sec]そのときに、あの[1.5sec]会社で働く、ホテルに泊まりまし た。あの[2.5sec]それに、あの[3sec]あの、そこにオースティンにあります。それか ら、あの、ウェストテキサスに行きます。でも、ウェストテキサスには airbnbに 泊まります。あ、泊まりました。

$\mathrm{T}:$ あの、その働く会社のホテルっていうのは?

$\mathrm{J}:$ ポートランドのホテルの名前は、ホテルヴィンテージ。あの、スペイン料理レ ストランで働きました。

$\mathrm{T}:$ じゃあ、そのレストランのチェーンのホテル?

J: はいはい、そうです。

$\mathrm{T}:$ いいホテルでしたか?

J: はい、あの、ルームは、ルームの、家賃?

$\mathrm{T}$ : 家賃というか、部屋代? 
J: あ、はい。忘れました。@高いですが、自分で...ディスカウントありました。

$\mathrm{T}:$ そうですか。どうしてディスカウントがあったんですか?

J: あの、その、会社働きますので。

$\mathrm{T}$ : ふーん、なるほじ。わかりました。じやあ、あの次のクエスチョンですけじ、 そうですねえ、えーと、いつも誕生日はどんなことをしていますか?

$\mathrm{J}:$ どんなこと、誕生日は...このごろしませんね。

$\mathrm{T}$ : じゃあ、例えば、むかしの誕生日で、よかった思い出とかありますか?

$\mathrm{J}:$ [2sec]あの一...今年は、バーで、行きました。たくさん友達に行きました。 ... でも、あの...んー少し時間、行きました。んーちょっとつまらないんです。

$\mathrm{T}$ : じゃあ、例えば小さいころとか、高校生のころとか。

$\mathrm{J}:$ 親は大きいパーティをしました。

T: ああ、そうですか。

$\mathrm{J}:$ 毎年。親はいい親ですよ。たくさんプレゼントを*あげました。

$\mathrm{T}:$ そうですか。どんなプレゼントですか？

J: あの...わたしの...歳?によって違います。例えばは、あの...22 歳の誕生日は、 あの一...フランス語、フランス人の作家、あの、長い小説、あの、あの、母、母が、 あの、その本を買いました。あの、長い小説。あの、作家の名前は、マーセルプ ルーストです。

T: ふーん、お父さんからは何かありましたか?

$\mathrm{J}$ : あの[2sec]カードとか...@@時々、本とかを買います...買いましたが、あの、何 か...忘れました。@

T: @じゃあお母さんからたくさんもらったんですか?

J: はい。

$\mathrm{T}$ : ヘー。じやあ、次、ちょっと教えてほしいんですけど、えーと、ジョンさん が、色々な友達とか、家族とか誰でもいいんですけど、誰が一番親切だと思いま すか?

\section{$\mathrm{J}:$ 親切?}

$\mathrm{T}$ : うん、親切っていうのは、kind とか generous とかという意味ですね。

$\mathrm{J}$ : あの一[2sec]とにかく、みんな、あの、親切ですけど。あの、一番親切な人で 寸亦え...う一ん[3.5sec]あの一、母と思います。今年の夏はテネシーに行きま、行 くつもりですが、あの、母と住んでいます。

T: あ、お母さん、テネシーに住んでいらっしゃるんですか?

J: はい、あの、父も。

T: あ、そうですか。へーじゃあ、例えば、お母さんが、あの、お母さんが本当に 親切だなーって思ったときって、いつですか? どうしてそう、一番親切だと思い ますか?

$\mathrm{J}$ ：あの、うーん[2sec]@恥ずかしですけど@あの、母は、あの[5sec]映画の好き... 映画好きな...女の、趣味を㹸げました。あの、私は母と、あの、いつも古い映画 を見ました。

T: じゃあ、お母さんとたくさん映画を、見て、映画が好きになったんですか?

J: はい、そうです。そうです。 
$\mathrm{T}:$ じゃあ、お母さんは、違う人にも親切ですか?

J: はい、あの、そして ...あの...母を....つも本を読んでいます、読みました。あ の、私と弟は、あの、どんな本ですか。あの、こどものときに、は、あの、あの、 あ...たくさん本を読む、読みました[1.5sec]ん一、あの、あの、読書。

T: じゃ、あの、ジョンさん、と弟さんが寝る前にお母さんが本を読みましたか?

J: はい。

T: それはいいお母さんですね。へー。

$\mathrm{T}$ : じゃあ、次なんですけど、例えば、ジョンさんが何か大変なことがあったと きに、誰に相談しますか?

$\mathrm{J}:$ あの、う一ん、最後の大変な時に、ウィリアムズ先生に相談しました。いいア ドバイスを*あげました。でも、あの、去年の夏は、日本語の 200 レベル、あの、 そのレベルは、全部をできました。その夏は 9 週間でした。そしてあの、大変相 談...これは、大変相談しました。でも、あの、ウィリアムズ先生がわかりました。

$\mathrm{T}:$ う一ん、じゃあ、ウィリアムズ先生が...女の、いいアドバイスしましたか?

J: はい。

$\mathrm{J}:$ それでは、今、秋学期は、卒業、あの...するつもりです。

$\mathrm{T}$ ：よかったですね。もうすぐですね。よかったですね。じゃあ、次ですけど、 一番感謝している人はですか?

$\mathrm{J}:$ 感謝? 感謝? その言葉は?

$\mathrm{T}$ : 今日勉強しましたね@感謝はありがとうの気持ちです。

J: ああ! 誰が? @

$\mathrm{T}$ : 誰に感謝していますか?

$\mathrm{J}:$ 女一[3sec]@その質問は大変ですね@たくさんの人ですね。一人だけじゃない です。あの、あの、みんな、先生と、あの、母と父は...あの、あ、そして、あの、 弟。[2.5sec]あの、みなさまは、手伝う、手伝いました。困るときに、あの、サポ 一トしました。

$\mathrm{T}$ そうですか。じゃ、例えば、友達の中で誰に一番感謝していますか?

J: あ、そうですね。あの一、仕事の友達は、あの、最後の病気にいきましたけど、 あの、あの、彼は、あの、病気、病院に泊まりました。私と。

T: あ、ジョンさんが病院にいるときに?

J: はい。

T: あ、どう思いましたか?

$\mathrm{J}$ : あの、うれしいです。あの、その人はたす、たすか、たすか...助かりました。

$\mathrm{T}$ : じゃあ、その感謝の気持ちをどうやって伝えましたか?

$\mathrm{J}:$ あの、あの、その友達は、あの...困るときに、あの...私は手伝ってと思います。

$\mathrm{T}$ : なるほど。いい友達ですね。なるほど。じゃあ、質問はここまでです。あり がとうございました。

$\mathrm{J}:$ ありがとうございました。

\section{T: Takizawa (Interviewer), C: Subject\#3: Chris}

$\mathrm{T}:$ えっと、出身はどこですか? 
C: ポートランドです。カリフォルニアに生まれましたけど。やっぱり出身は。

$\mathrm{T}$ : ポートランド。あ、カリフォルニアで生まれたんですか? 何歳の時にポート

ランドに来たんですか?

C: いちさ、いっさい。

$\mathrm{T}:$ じゃあ、高校は? どこに?

C: 高校は? T という高校です。

$\mathrm{T}$ : それは?

C: サウスイーストにあります。

T: あ、そうですか。じや、クリスさんが、日本語を勉強しようと思ったきっか けはなんですか?

C: きっかけは、う一ん、やっぱり、子供のころからいつもまんがとか、あの、 日本の音楽を聴いたりしていた。あの、漫画を描くことを練習して、グラフィッ クデザイナーになりたかったんです。大学に行って、あの、だい...ま女...グラフ イックデザインを勉強している人は、まあ、言語学も勉強しなくちやいけない場 合、ですので、日本語を決めて、日本語の授業を初めの日が、すごくおもしろか ったので、まあ、日本語を勉強するつもりになりました。

T: あ一なるほどねえ。じや、最初のメジャーは、専攻は、グラフィックデザイ ンにしようと思っていたんですか?

C: そうですねえ。

T: ああ、そうなんですか。へえ、それで、その、初めての日本語でおもしろい ๖て...

C: うん。

T: じゃ、そのときはじめて、あの、日本語を勉強しましたか？

C: はい。

$\mathrm{T}:$ そうなんですか。じやあ、高校のときとかはぜんぜん？

C: まあ、この前に平仮名とカタカナを勉強していましたけど、文法は本当に全 然わかりませんでした。

T: ああ、そうなんですか。すごい、ですね。まだ、勉強して一年とちょっとで すよ䣊。

C: ちょっとです。

T: いや、すばらしい@な

C: @@

T: @えー、じゃあ、クリスさんは、例えば、高校とか大学とか、いつでもいい んですけど、好きな先生は誰ですか?

C: 好きな先生は...あ、まあ小学校に、モリ一っていう先生。あの、ま、文学と、 作者。まあ、文学を勉強している人と作者でした。あの一、その授業に、モリ一 先生の書いた本を読みました。本当におもしろかったです。それで、あの...モリ 一先生が、效え、悋え、先生になってないよと言われましたけど、あの...ま... そ の文は本当にかっこいいと思ったんですよ。

$\mathrm{T}$ : その本がですか? 
C: いや、まあ、授業、ほかの、ほかのときの授業には、あの、まあ、先生にな りたくなった先生ですけど、なりたくなかった先生です。作者になりたいいつも と言ってばかりでしたけど、ほかの日は、悋え䘛、子供たち、先生になってな いよ、と言って教えてくれました。

$\mathrm{T}:$ じゃあ、先生じゃなくて、本当は、本の作家になりたかったんですね。

C: うん。

$\mathrm{T}$ : じゃ、でもどうしてその先生が一番好きだと思いますか?

C: あーまあ、自分のゴールを、教えて...くださいましたから、わたしのゴール はもっと...ま...やる気になりました。

T: なるほどね。授業はどうでしたか?

C：あ、本当におもしろかったです。いつも。先生は...まあ、いい...ま、かっこ いい声でも話しましたから。

$\mathrm{T}:$ うーん。どんなことしましたか? 授業で。

C：あの一、ま、本についてと、自分のゴールとか、自分の本を作りました。

$\mathrm{T}$ : あ、クリスさんが自分の本を作ったんですか?授業で?

C: うん。

$\mathrm{T}$ : へえ、面白いですね。それは。

C: ほかの授業ではその予定がいな、あ、ありませんでしたから、モリー先生が 本当にかっこいいと思ったんです。

T: ぶん、じや、ちょっと、特別な先生だったんですね。

C: うん。

T: なるほど。わかりました。じやあ...あの...クリスさんは、旅行とかしたこと ありますか?

C: そうです。

$\mathrm{T}:$ 海外旅行はありますか?

C: 海外というのは?

$\mathrm{T}:$ あ、あの...アメリカ以外の国に旅行したことありますか?

C: ありませんね。ま、カナダだけですけど。

$\mathrm{T}$ : 旅行しているときに、誰かにお世話になったことはありますか?

C: あ、旅行したときに妹とか[2sec]、ほかにも ...

$\mathrm{T}$ : なんか例えば、旅行に行って、知らない人ばかりで、誰かが助けたりとか。

C: [5.5sec] いませんねえ。@

$\mathrm{T}:$ @じゃあ、いつも一人で?

C: あ、ちょっと、小学生の時にもワシントンに行って、あの、母の家族を会い ました。実は、私の家族はロシアにいて、あの[1.5sec]そのときに、わたしワシン トンに行って、あの、ワシントンの家族、母の家族を手伝ってあげました。うん、 はかてで。

T: はか?

C: はかて?はかて?

$\mathrm{T}$ : [2sec]

$\mathrm{C}$ ：農家、農家なんですよ。 
T: あ、じゃあ、クリスさんがお手伝いしたんですか?

C: うん。いつも手伝って...手伝っていて、あの、ほかのいこと?いとこ?

T: いとこ、ね。

C：はい、いとこをちょっと連絡して、ねえねえ、いつも、わたしが仕事してい るので、わたしにちょっと、あ一、ほかのおもしろいところに連れて行っては大 丈夫か? と言って、あの、まあ、本当に助かりました。

$\mathrm{T}:$ な、な、いとこと何したんですか？

C：川に行って、川に行ったんですよ。川に行って、まあ、自転車に乗って、楽 しみました。

$\mathrm{T}$ : ふーん、そうですか。へえ、え、どんないとこなんですか?その人。

C: デイビッドといういとこです。同じ歳ですよ。

$\mathrm{T}$ : へえ、同じ年齢なんですね。

C: うん。

$\mathrm{T}:$ ふーん、そう。今でも連絡したりしますか?

C: ちょっとだけですけど。

$\mathrm{T}$ : ふーん。わかりました。いいですね。じやあ、あの次の質問ですけど、あの、 クリスさんが、知っている人の中で、誰が一番親切だと思いますか?

C: 親切?

$\mathrm{T}$ : 親切っていうのは、やさしいとか、generous とかkind という意味ですね。誰 が一番親切だと思いますか?

C：そうですね。やっぱり彼女ですねえ。@@

T: @ああ、そうですか。

C: はい。

$\mathrm{T}:$ それは、なんで?

C：ああ、まあ、例えば、うーん、ほかの授業には、作文を書いてはいけない場 合がありますけど、あの、ま、本当に大変な作文なので、私の彼女は、文学とか、

ま、あ一、作文を書くことに強い人、なので、私を手伝っであげています。いつ も。

T: へえ、いい彼女ですね。

C: @@

$\mathrm{T}$ : これもちょっと似ている質問かもしれないですけど、人生で何か大変なこと があったときに、誰に相談しますか？...とれか、誰に相談しましたか? どっちで もいいです。

C：うーん[2sec]まあ、その大きな問題、誰にも相談していませんけど、ああ、時々 父だと思います。父はいつもいいアドバイスを教えて[2.5 sec]あ、く、くれていま す。

T: たとえば、どんなときにアドバイスありましたか?

C: 成績が弱くなったときとか。@うーん・・悪い彼女、をデートしたときも いいアドバイスを教えてくれたんですよ。

T: ああ、そうですか。へえ、いいお父さんですね。

C：そうと思います。 
T: じゃあ、次のクエスチョンですけど、次に、一番感謝している人は誰ですか?

C: 感謝っていうのは?

$\mathrm{T}$ ：感謝、昨日の授業でしたじゃないですか@@

C: そうですか。@

$\mathrm{T}$ : 感謝っていうのは appreciate とか gratitude とか。りり゙とうっていう気持ち。

C: う一ん。

$\mathrm{T}$ ：誰に一番感謝していますか?

C: 父と先生。

T: ああ、そうですか。じやあ、どうしてお父さん?

C: 父は、まあ...例えば、まあ、金がなければ、この大学に行けないはずだった のに、父が手伝ってあげました。

T: うーん、ああ、そうですか。

C: ほかの大学の日本のプログラムは、ちょっと、まあ、まあまあですけど。大、 ポートランド州立大学の日本語のプログラムは本当にいいと思います。

T: ああ、ありがとうございます。@

C: @@

$\mathrm{T}$ : じゃあ、お父さんがお金を払いましたね。それについて、お父さんに感謝の 気持ちを伝えましたか?

C: ん?

$\mathrm{T}$ : ありがとうって、クリスさんから、ありがとうっていう気持ちを。

C: 見せました。見せましたよ。

$\mathrm{T}:$ どうやって?

C: まあ、言葉で。@

$\mathrm{T}:$ @なんて言ったんですか?

C: あ、本当にありがとうございます。ねえねえ、あの、まあ、いつも先生につ いて話しましたとか。あの一、それで、あ[1.5 sec]家で、仕事しています。

$\mathrm{T}$ : 家で、仕事?だ、誰がですか?

C: まあ、父の仕事 $[1.5 \mathrm{sec}]$ とか。亦え、ねえ、私が手伝ってあげるよ。と言った り。もっともっと。

T: あ、なるほど。そうなんですか。それはいいですね。さっき、先生にも感謝 しているって言いましたけど、どうして、先生に感謝していますか?

C：ああ、まあ、先生が私の日本に行きたいこと、よく知っていますから、あ、 あ、わたしを、手伝ってくださいました。

$\mathrm{T}$ : じゃあ、最後の質問ですけど、あのー、クリスさんは、いつも、誕生日はど うやってすごしますか?

C：うーん、友達、私の家に、行って、来て、ゲームをしたり、ピザを食べたり、 うーん...ほかのところに行ったり、例えば、ま、川とか、パーク、公園の、とこ ろに行っています。

$\mathrm{T}$ : じゃあ、一番よかった誕生日の、思い出はありますか?

C: うーん[1.5sec $]$

$\mathrm{T}$ : 小さい時でもいいですよ。 
C: さっきのは本当によかったと思います。

$\mathrm{T}:$ さっきのって何ですか?

C: あ...さっきの誕生日?

$\mathrm{T}$ : あ、前の誕生日ですか?

C: あ、前の、すみません。

$\mathrm{T}:$ 去年ですか?

C: はい。

$\mathrm{T}$ : ふーん、何したんですか?

C： あの、友達は私の家に行って、あの、まあ $[1.5 \mathrm{sec}]$ その人は...両親が、プレゼ

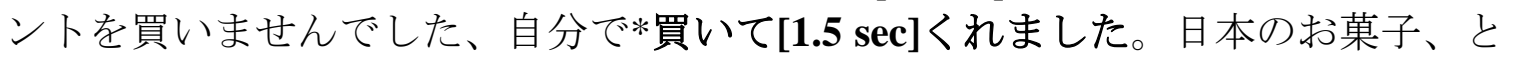
か...バーベキューわさびの味チップスをくれました。それでゲームを、ゲームが 楽しかったです。

T: あ、ゲームしたんですか。彼女からははなにかプレゼントありましたか？

C: あ、日本についてカレンダー贈りました。

$\mathrm{T}:$ じゃあ、そのカレンダーもらったときどういうリアクションしましたか?

C: ああ、かわいいですね。@

$\mathrm{T}$ : @壁に貼りましたか?

C: うん、そうしました。

$\mathrm{T}$ : そうですか、あ、質問はここまでです。どうもありがとうございました。

J: はい、ありがとうございました。

\section{T: Takizawa (Interviewer), E: Subject\#4: Eric}

T: 高校はどこに行ったんですか?

E: …女、高校? 高校生の時?

T: はいはい。

$\mathrm{E}: \quad \mathrm{P}$ 高等学校に行きました。

T: じゃあそのとき、あの、日本語を勉強していましたか?

$\mathrm{E}:$ あ、いえ、Pでは日本語はありませんでした。

T: あ、そうですか。じやあ、日本語はどのぐらい勉強しているんですか?

E: うーん、ちょっと、ええ[1.5sec]そのときは一年間ぐらい。

$\mathrm{T}:$ ふーん、あ、高校生の時?

E: いえいえ、このとき。

$\mathrm{T}$ : あ、今回?

E: はい、今回は一年だけど、前は、もう一年間ぐらい。

T: じゃあ、どうして日本語を勉強し始めたんですか?

E: はい。えと、大学...には、えつと、いい先生がいました。えと、えと、その 先生は日本人。日本文学、あ一、を、あ、教えていました。えと、その授業を... えっと、とったら、えっと、興味が、興味を持つようになりました。

$\mathrm{T}$ ：ふーん、そうですか。じやあ、いろんな先生が、いると思うんですけど、一 番好きな先生は誰ですか? PSU だけじやなくて、なんか、いろんな学校で。どこ の学校でもいいです。一番好きな先生いますか? 
E: えー ..うーん[9sec]うーん[10.5sec] と、ええ、先生は、っと、ちょっと子供よ うなもの@一番好きなのじゃないですねえ。@

T: @ああ、そうですか。じゃあ、一番じゃなくてもいいです。好きな先生。

E: ああ、えっと好きな先生なら、ジョーンズ先生です。

$\mathrm{T}:$ ジョーンズ先生。なんの先生ですか?

$\mathrm{E}:$ 文学じゃなくて、文学の、えー、作り。

$\mathrm{T}$ : 作り?

E: あー、いえいえ。英語では Creative Writing?

T: あ一、なるほど。作文ですね。

$\mathrm{E}$ : 作文。けど、自分が、クリエイティブライティングの授業を、とっていませ ん、でした。けど...えっと、その先生はすごく賢い...えっと、よく、えっと、い い、うー[3sec]ん[10sec]とてもいい教えを、えっと、くださいました。

T: ああ、そうですか。なるほどね。ふーん、じゃあ、エリックさん、いつも誕生 日とかはどうやってすごしていますか?

E: ああ、誕生日...えっと ...最近よく友達と、会いました。えつと、別に何もあ ーえっと、しませんけど、楽に...えっと...います。

T: うん、じやあ、例えば子供のころとか、何か、よかった誕生日の思い出とか ありますか?

E：うーん、子供の頃でも、誕生日は特の日....すごく特の日じゃなかった。

$\mathrm{T}$ : 特別な日?

E：特別な日じゃなかったんですが、けど、思い出が、えっと、あまりありませ 几。

T: うん、そうですか。わかりました。じやあ、例えば、今、友達と誕生日を過ご して、友達からからプレゼントとかありましたか?

$\mathrm{E}:$ 自分に?

T: はい。

E: ふーん、ときどき、えっと、えー、ランチをおごります。

$\mathrm{T}:$ あ、じやあ、お酒とかは?

E: お酒もおごります。@

T: @あ、そうですか。じやあ、次の質問なんですけど、留学はしたことはあり ますか?

E: あ、いえ。

T: あ、そうですか。じやあ旅行はしますか？

E: あ、はい。

T: あ、そうですか。じやあ、なんか旅行中に誰かにお世話になったことがあり ますか?

E: うーん[6sec]うーん[5.5sec]一人旅のこと ...が、えっと、ない...ありませんから ...えっと、私に、私がお世話になる人、が、あまりありません、けど、うちの家、 に、っと[3.5sec]う一ん[4sec]ちょっと違います。えっと、高校生のとき、Israel?

$\mathrm{T}$ : イスラエル。 
E: イスラエルに行きました。えっと、そ、そのとき、あー... 一間、ぐらい、 あー、えっとー[5sec]うーん...えっと、うーん、え、すごく、おもしろい観光? [2sec] 観光者?あ、観光の案内の人、えっと、と会いました。えっと...うーん、おもし ろい人物だと思いました。

T: ふーん、どうしてですか?

E: えっとー、うーん、いつも、えっとー、ちょっとうるさい、けど、うーん[2sec] うるさいし、えっと、えー、運転がすごく悪いし、それでも、えっと、優しい人、 でした。

$\mathrm{T}:$ え、例えば、どんなことで優しいと思いましたか?

E: おばあちやんと、えっと、あ、旅行、する、したんですが、えっと、その人 はいつもおばあちゃんに優しかったんです。

T: あ、エリックさんのおばあさんと旅行したんですか?

E: あ...はい。

T: あ、そうですか。例えば、どんなこと...ですか? 優しかったことって。

E: いつも、えっと、うちのおばあちゃんを、えっと、ママレと言われました。

$\mathrm{T}$ : ママレ?ママレって?

E: えっと、えー、Pet name。えっと Term of endearment.おばあちやん、みたい。

$\mathrm{T}:$ ヘー。じゃあ、その人のうちに泊ったんですか?

E: いえ、泊まりませんでした。

$\mathrm{T}$ : ふーん。わかりましたじゃあ次の質問なんですが、エリックさんの知ってい る人の中で、誰が一番親切だと思いますか?

E: [10sec]えー大学の友達のメグさんだと思います。えと、メグさんは、うーん、 えっと[10 sec]いつもほかの人の悩みを、えと、あ、聞いて[5sec]え、くれて、えっ

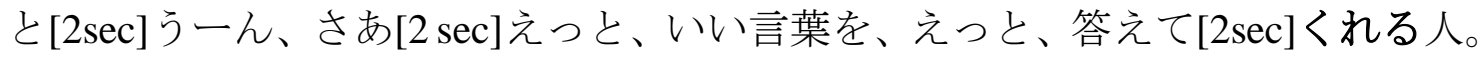

T: そうですか。メグさんとはまだ連絡とかしますか?

E: はい。

T: あ、いいですね。じゃあ次の質問ですけど、エリックさんが人生で大変なこ とがあったとき、誰に相談しますか?

E: うーん[6sec]よくメグさんに相談しました。あのとき...えっとー...メグさんは いい相手になります。

T: ふーん、じゃあ、メグさんはどんなアドバイスをしましたか?

E: うーん[14sec]えー、具体的な例え、ちょっと今は、思い出せない.... ど、う 一ん、普通は具体的なことじやない。えっと、えー[2sec]自分を、えっとーえー支 えて...くれる、アドバイス。

T: ふーん、そうですか。

E: わかりますか?

$\mathrm{T}$ : ええ、わかります、わかりますよ。じゃあ、次の質問ですけど、エリックさ んがじやあ、一番感謝している人は誰ですか?

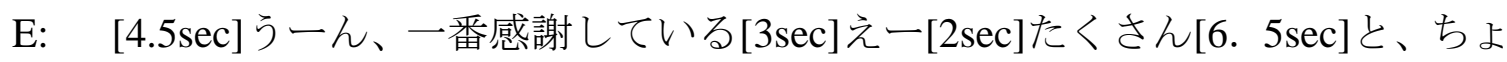
っとセリフの答えなんですけど、うちの母なんです。

T: ああ、そうですか。セリフ? 
E: セリフ ...つと Cliché?

T: @なるほど、ありきたりな、ですね。どうしてお母さんなんですか？

$\mathrm{E}$ : 子供の時、いつもお世話になりました。

$\mathrm{T}:$ うーん、具体的に何かありますか?

E: えーっと、うーん[23sec]えっと一、例えば[3.5 sec]ある時、えーと、えー、う 一ん、子供のころの時、えっとー、えー[4.5 sec]学校で、えっと、ちょっとえー、 問題が、あー、出ました、が[1.5sec]えっと、うちに、えっと、帰りませんでした。 あ一、恥ずかしかったんです。あ一、けど、母は、自分を探してくれました。

T: うーん、優しいお母さんですね。じゃあ、ほかに誰かいますか? 感謝してい る人。

E: ええ、[3sec]じやあ、えっとーえー[2.5sec]えー例えば、あの、前のいい先生。 ジョーンズ先生。

$\mathrm{T}$ : ああ、ジョーンズ先生。どうしてジョーンズ先生には感謝していますか?

$\mathrm{E}:$ うーん[5sec]賢い言葉。えーと、えー ... [7.5 sec]具体的...うーん、あ一、例えば、 えっと、えー、日本語でちょっと言いにくい、なんですけど、えと、卒業式で、 えっと、えー、これを、えっとくださいました。えっと、えー、うちの、えっと、 大学、えっと、生徒が一人一人、えっとー[3.5 sec]卒業式で、あ一、えっと一...え 一[4.5 sec]ある人 $[2.5 \mathrm{sec}]$ をる人を、ある人にスピーチを、えっと、えー、させる ことになっています。えっと、ミラー先生は自分のスピーチをやっていました。 えっとー、え、そのとき、えー、これを[2sec]えっと、くださいました。

$\mathrm{T}$ : それはなんですか?

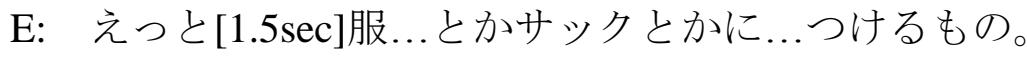

$\mathrm{T}$ : たぶん日本語でワッペンですね。

$\mathrm{E}:$ ワッペン?

T: はい、じやあ、ミラー先生にどうやって感謝の気持ちを伝えましたか?

E: えつと、自分が?

T: はい。

E: ああ、えっと、うーん[23sec]ふーん[25sec]大きな事じやなじゅて、じゃなか った、けど、ジョーンズ先生は大きな事が好きな人、あ、じやありません。えっ とー、ただ、あ、えっと、心のそとから、あ、感謝しました。

$\mathrm{T}$ : 心のそと? 底から?

E: そと。

$\mathrm{T}$ : そと、アウトサイド?

$\mathrm{E}:$ そこ?

$\mathrm{T}:$ そこ。ボトム?

E: はい。

$\mathrm{T}$ ：心の底から、直接先生に言いましたか？

E: はい。

T: あ、そうですか。先生何て言っていましたか?

E: 少し笑っただけでした。えっと、日本語では言いにくい。けど[7sec]英語でな んか、knowing smile。 
T: ふーん...knowing smile、ちょっとやってみてください。

E: おー、自分ではできません@

T: @あ、そうですか。@じゃあ、終わります。ありがとうございました。

E: いえ。

\section{T: Takizawa (Interviewer), L: Subject\#5: Lisa}

$\mathrm{T}:$ えっとーリサさんは、出身はどこですか?

L: ミズーリ州です。

T: うん、そうですか。じや高校はミズーリ州の高校に行きましたか？

L: はい。

T: ふーん、そうですか。じや、日本語はどのぐらい勉強していますか?

L: あのー、3、4 年勉強しています。

$\mathrm{T}:$ ふーん、3、4 年ですか。へー、日本語を始めようと思ったきっかけは?

L: あのーポートランドに引越ししたときは、あの一友達や、暇、暇じゃない、 趣味はありませんでしたから、趣味を見つかりたかったから、あの、子供のとき のアニメを見ました。あの、それから日本語で見るのをはじめました。

T: ああ、そうですか。じゃあ、それはポートランドに来てから?

L: はい、はい。

T: じゃあ、あの一、いろんな先生から勉強したと思うんですけど、日本語とか ほかの、クラスとか、なんでもいいですけど、誰が一番好きな先生ですか?

L: あ、そうですか。あの、今の先生が大好きですけど。

$\mathrm{T}$ : そうですか。あの、今までの先生で、誰でも。

L: 一番おもしろい先生は、高校の時の、あの、Social Studies? あの、その先生。

T: ふーん。あ、そうですか。

L: とても変な人でした。@

$\mathrm{T}:$ @なんでその先生が一番好きですか?

L: あの、変な教え方を使いました。とても変でした。@あの、ある日、授業の 全部は歌いました。とても変な歌でした。いい歌じゃなかったです。@

T: @じゃあ、その先生の教え方が好きだったんですか?

L: はい、はい。私はいつも笑い出しました。いつも変なことを言っていました。

$\mathrm{T}$ : じゃ授業で、なにか、その先生との思い出ってありますか?

L: はい、あの、ある日は、あの、子供の猫についての本を読みました@あの、 でも自分の、話をつけました。あの...

$\mathrm{T}:$ あ、先生が本を読んだんですか?

L: でも、先生の自分の話をつけました。

$\mathrm{T}$ : あ一。

L: それで、猫の名前はトビーでした。これは、トビー。トビーは、自分を洗い ます。オーブンのように。

$\mathrm{T}$ : オーブン? 自分で洗いますか?

L: あの...オーブンは自分で洗いますから。アメリカで、Self-Cleaning ボタンが ありますから。 
T: あ一、なるほど。おもしろい先生ですね。

L: はい。@

T: じゃあ、リサさんは、誕生日の、誕生日、いつも、どんなことをして過ごし ますか?

L: ちょっと、別に何もあの一...大きいしませんけど、友達や家族といっしょに、 あの一、あー、レストランへ、あー...行くし、あのー、バーへ行きます。

$\mathrm{T}$ ：んー、なるほどね。じやあ、あの子供のときとか、は、すごくよかった誕生 日の思い出ありますか?

L: はい、あの、母は美術が好きですから、いつも、小さいクラフトのことをし ました。あの一、あー[2sec]スターフィッシュ、わかりますか?

$\mathrm{T}:$ はい、わかりますわかります。ひとで。

L: あの一[1.5sec]からからのスターフィッシュで、たくさんことを作りました。 かわいいことになりました。あの、クラフトでした。それは、お誕生日のパーテ イのアクティビティでした。そんなこと。

$\mathrm{T}$ : ヘー、なるほど。そうですか。なにかプレゼントとかはありましたか?

L: はい、あのー、うーん、あのー...番いいプレゼントは、実は、クリスマス でした。それは、インコでした。@

$\mathrm{T}$ : あ一、なるほど。インコは誰からですか?

L: 母でした。

$\mathrm{T}$ ：他に例えば、違う人からありましたか。プレゼント。

L: はい、あの一、彼氏から。ちょっとさびしいですけど、こどものときからの 猫が、あの、死にました。それで、plushy を買いました。その放このような plushy を買いました。

T: ああ、彼がですか?

L: はい、そのときたくさん泣きました。

T: ああ、そうですか。じやあ、つぎの質問ですけど、旅行はしますか?

L: はい、でも最近はお金がありませんから。@

T: じやあ昔の旅行でもいいんですけど、誰かにお世話になったことはあります か?

L: たぶんあります。いつも、あの一...こどものときは、おじいさんとおばあさ ん、子供のときは、いつも私に[5sec]手伝うことがありました。あの、いつも、あ の、世話をしました。

$\mathrm{T}:$ じゃあ、あの、おじいさんとおばあさんは、どんな人ですか?

L: あの一、あ一、子供のときは、あ、母は大学に帰りました。また行きました。 あの、それ、そのときは、あの、そのおじいいちゃんとおばあちゃんは私を、あ の、ちょっと育てました。

T: あ、そうなんですか。へー。じゃあ、なにかおじいさんとおばあさんとの思 い出ありますか?

L: はい、たくさんあります。

$\mathrm{T}$ : じゃあ、例えば、何かいい思い出を教えてください。 
L: 小さい、小さいこどものときに、あの、あ一、小学校の前に、あの一、お、 おばあさんは、まだ仕事ありましたから、母も仕事ありました。いつもおじいさ んと一緒、あ、一緒でした。あの、あ、毎日車で、あの、セントルイスで運転し ました。

T: ふーん、ああ、そうなんですか。え、じゃあ、例えばなにかおじいさんとお ばあさんから、何かプレゼントとかはありましたか?

L: はい、あの一あ一、おばあさんはいつも新しいゲームシステムを買いました。

@

T: あ、そうですか。へー。

L: 英語で spoiled しました。

T: わかります。日本語で甘やかすといいます。

L: はい、そうしました。@@

$\mathrm{T}$ : じゃあ、次の質問ですけど、知っている人の中で、一番親切だと思う人は誰 ですか?

L：それは難しいと思います...あの、母と彼氏と思います。いつもその人たちと 一緒にですから。よく私のこと知っていますから。

T: じやあ、どんなときに、親切だな一、とかやさしいなーって思いますか?

L: はい、あの、いつも、小さいことを、彼はします。ときどき、あの一、掃除 をします。私は、掃除が嫌いですから。あの、いつも彼は、私に任せてください。 私はありがとうございます。@@小さい親切ですけど、とても大切です。

$\mathrm{T}$ : 本当ですね。じやあ、お母さんは?

L: あの一、お母さんとわたしは、いつも庭で、あの、ガーデニングをします。 いつも花を買ってくれます。

$\mathrm{T}$ ：あ、そうですか。へー。やさしいですね。じやあ、つぎなんですけど、もし、 リサさんの人生で、大変なことがあったとき、誰に相談しますか?

L: ちょっと、変ですけど。猫。@ちょっと話じゃないですけど、猫と、あの一、 猫といるのは、とても安心します。

$\mathrm{T}:$ うーん、そうですか。じゃあ、猫に、話すんですか?

L: いいえ、ちょっといるだけ。それはとても安心します。

T: ああ、そうですか。へー。じゃあ、人は誰か相談しますか?

L: はい、母と思います。

T: あ、そうですか。じやあ、お母さんからいいアドバイスとかありましたか?

L: はい。あの一、たぶんたくさん専攻を変わりましたから。そのときはいつも 母に、ああ、どうしますか。これが好きだけど、これも好きと言って、母は、自 分の好きなことしますと言っています。

$\mathrm{T}$ ：そうですか。そのアドバイスについてどう思いますか?

L: あの一、ちょっと、もちろんと思いますけど、聞くのがいい思います。

T: じや、自分の心ではわかってたけど、お母さんから聞くとうれしい。

L: はいはい。

$\mathrm{T}$ : じゃあ、次、最後の質問ですけど、人生で感謝している人は誰ですか?

L: あの一、はい、おばあさんとおじいさんと、母。 
$\mathrm{T}:$ それはどうしてですか?

L: あのー、たくさん、あの、努力をして、わたしを育てました。

$\mathrm{T}$ : う一ん、じゃあ、その感謝の気持ちがありますよね。じゃあ、それをどうや って、おじいさん、おばあさん、お母さんに伝えますか?

L: あの、まあ、おじいさんとおばあさんはまだなくなりましたけど。いつも、 あの人に考えました。いつも運転するときは、あの、おじいさんを考えました。

T: うーん、そうですか。じやあ、お母さんとはまだ、ね、一緒に住んでますけ ど、あの、どうやって感謝を気持ちを伝えていますか?

L: あの、たぶんガーデニングのことについて。あの、いつも二人も花を買って く*れます。

$\mathrm{T}:$ ふーん、二人も?っていうのは?

L: わたしと母。あの一、花を買っでくれます。あの、買い合います？

T: ああ、なるほどね。じやあ、ときどきお母さんが買ったり、リサさんが買っ たりするということですか?

L: はいはい。そうですね。

$\mathrm{T}:$ じゃあ、いい庭ができましたか?

L: はいはい、とてもいい庭です。あとで、写真を見せます。

T: あ、見たいです。じゃあ、ここまでです。じやあちょっと止めますね。あり がとうございました。

L: はい。

\section{T: Takizawa (Interviewer), S: Subject\#6: Steve}

T: スティーブさんは、出身はどちらですか?

S: あ、ジョージアのアトランタ市ですか?

$\mathrm{T}$ : ふーん、高校もアトランタですか?

$\mathrm{S}:$ [1.5sec]あ、はい。

$\mathrm{T}:$ ああ、そうですか。じゃ、ずっと、大学までフロリダ?

$\mathrm{S}$ : あー[1.5sec]ん、いえ、あの[4sec]あのじゅう...女、21 歳に、あ、アトランタか らマイアミまで、あ、引っ越しました。

$\mathrm{T}:$ マイアミ...ヘー、マイアミは、どうでしたか?

$\mathrm{S}:$ あーㄴ..とても…楽しい、楽しかったです。

T: ああ、そうですか。へえ、マイアミでは何していたんですか? 大学生ですか? それとも?お仕事?

S: いえ、あの、仕事です。仕事、あ、スーパーの店員。あの、あー、マイアミ、 4 年、間ぐらい住んでいました。それから、ポートランド、引っ越しました。

$\mathrm{T}:$ んー、そうですか。どうしてポートランドに引っ越したんですか?

S: あ一、そのときの彼女と一緒に引越ししました。

$\mathrm{T}:$ あ一、なるほど。

S: あの一、その彼女は大学院、に入りました。あー、それに、わたしがポート ランドに友達がいました。

T: ふーん、なるほど。 
S: ですから、@引っ越しました。

$\mathrm{T}:$ ヘー。じゃ、あの、日本語はどうして始めたんですか?

$\mathrm{S}$ ：あー…わ、若いときから、私が日本、がとても面白いと思いました。あの [1.5sec]歴史と文化、特におもしろいと思いました。

T: ふーん、そうですか。じやあ、あの、日本語を勉強し始めたのは PSU が初め てですか?

S: いいえ、C大学ではじめました。

T: あ、そうなんで寸か。じゃあ、高校の時は? 言語を勉強していましたか?

S: いえ、実は、少しスペイン語を勉強しました。

T: ヘーそうなんですか。

S: でもそれは、長い期間前...

$\mathrm{T}$ : 昔ですか?

S: うん、昔。@

$\mathrm{T}:$ じや、あまり覚えていないんですか?

$\mathrm{S}$ : そうそう。

$\mathrm{T}$ : 忘れちやいましたか。

S: うん。

$\mathrm{T}$ : じゃあ、スティーブさん、いろんな学校でいろんな先生から勉強したと思う んですけど、一番好きな先生は誰ですか?

S: えーとー、日本語の先生ですか?

$\mathrm{T}:$ いや、何の先生でもいいです。

S: う一ん、たぶん・..日本語の先生の今田先生。

$\mathrm{T}$ : ああ、今田先生。

S: し、知っていますか?

$\mathrm{T}$ : はい、わかります。はい。

S: いい人です。いつも笑います。元気です。

T: じや、今田先生とどんなことを一緒にしましたか? 授業のときとか。

S: う一ん、普通の授業の‥ことだと思います。

T: たとえば、この授業がおもしろかったとかありますか?

$\mathrm{S}:$ あ一、今田先生の授業はいつも楽しい。楽しい、感じる。感じます。

$\mathrm{T}$ : ふーん、そうですか。なるほど。何か思い出？メモリーみたいなことはあり ますか? 今田先生との。

$\mathrm{S}:$ うーん[6sec]別の思い出がありません、けど。

T: あ、特にありませんか。

S: はい。

$\mathrm{T}$ : じゃあ、毎日の授業が先生が楽しかった。

S: はい。

T: えーと、じやあ、次の質問なんですけど、いつも誕生日はどうやって、すご していますか?

S: 私の誕生日ですか?

T: はい。 
S: あーん、普通は、静かな日を過ごします。時々友達と一緒にレストラン、に、 行きました。行きます。

$\mathrm{T}$ : じゃあ一番よかった、レス、レストランじゃない、誕生日?は、いつの誕生 日ですか?

$\mathrm{S}$ : あの[3sec]うーん[5.5sec]静かの、静かな日をすごして、友達と一緒にレストラ ン、に...あ...行って、それから、あの[4.5sec]バーと居酒屋の[5.5 sec]う一ん、の、 飲むことがいいと思います。

$\mathrm{T}$ : 飲むのが好きなんですね。

S: @

$\mathrm{T}$ : 小さいころの誕生日で思い出はありますか? よかったなーとか。嬉しかった な一とか。一番良かった誕生日。

S: うーん、[2sec]まあ、あの‥誕生日は、あ一、あの、一つだけ覚えていますけ じ、あ一、私の家に友達、たくさん友達に来て、ケーキを食べて、あの、外で... アメフトをしました。

T: ふーん、あ、じゃ、パーティをしたんですか?

S: ええ、それは楽しかったです。

$\mathrm{T}:$ プレゼントとかありましたか?

$\mathrm{S}:$ うーん[5sec]あるかどうかわかりま、覚えてない、覚えてません。

T: あ、そうですか。たとえば家族からプレゼントはありましたか?

S: たぶん。

T: たぶん?@

S: ええ、でも覚えていません。

T: あ、そうですか。じやあ、今の、最近の誕生日でプレゼントとかありました か?

S: うーん、ありませんと思います。@

T: ああ、そうですか。@じゃあ、普通はレストランとかバーに行って、食べた り飲んだりして。

S: そう。たぶん、レストラ、レストランで友達が払うことはプレゼントです。

T: うーん、なるほどね。じやあ、お金を出してくれるんですか?

S: はい。

$\mathrm{T}:$ いいプレゼントですね。

S: うん。そうです。

$\mathrm{T}:$ たくさん飲むんですか?

S: うん、時々。でもこのごろは少し、少なくなります。

$\mathrm{T}$ : そうですか。ちょっと気を付けているんですか。@

S: はい。@

$\mathrm{T}$ : そうですね。飲みすぎは体に悪いですからね。

S: うん。

$\mathrm{T}$ : そういえば、スティーブさんは留学していましたよね。

S: はい。

$\mathrm{T}$ ：留学中に誰かにお世話になりましたか？ 
S：お世話になった人は、田中さんです。田中さんは、あ一、大阪大学の、うー ん、国際学生センターのプログラムディレクターです。あー、留学生が、質問が あったら、あ、田中さん、に聞いて、田中さん、あー、が? 田中さん*に? 手伝っ てくださいます。

$\mathrm{T}$ : そうですか。

S: はい。それに、私が留学生のときは、あ...万、6 ケ月でしたけど、私がもう 6 ケ月日本にあ・・いたかったですから、あ、田中さんに聞いて、あの[2sec]@たま あさんに聞きました。田中さんが手伝ってくださいました。あの一、それから、 もう六ヶ月日本にいることができました。

T: ふーん、なるほどね。へー、じやあ、あの、ほかの人で、とても親切だなあっ て思った人は誰ですか?

$\mathrm{S}:$ う一ん、あー、あ一、大学の日本語の先生が、先生たちが親切でした。

$\mathrm{T}:$ うーん、どんなときにそう思いましたか?

$\mathrm{S}$ ：あー、らーん....いらも、あ、うーん、アメリカ人の留学生がよく失礼してま したのに、あー、先生たちがいっも優しい、優しかったです。

T: そうですか。失礼って@どんなことですか? @

S: @あ一、授業で、食べること、飲むこと、呪談をして、あの一、話して。そう いうこと。

$\mathrm{T}:$ うーん、じやあ、そういう時、先生はどんな風に対応したんですか？

S: うーん[6sec]うん。あー、ちょっとわかりません。

$\mathrm{T}$ : 例えば、先生は、おこったりとか、注意したりとか?

$\mathrm{S}:$ あの一[2sec] 1、2 回だけだと思います。私の友達は、いつも失礼な人@アメ リカ人です。あの一[3.5 sec]授業で、あー、食べ、ければ先生、は、あ一[9.5 sec]scold?

$\mathrm{T}:$ ああ、しかります。

S: しかります。

$\mathrm{T}$ : それでも優しかったんですか?

S: うん、はい。

$\mathrm{T}: \mathrm{PSU}$ の先生と大阪大学の先生と比べてどうですか?

$\mathrm{S}$ ：あー[3sec]PSU の先生は若い人です。日本で...もうちょっとあ...How do I say? Older teachers?

$\mathrm{T}$ : もっと年上です。

$\mathrm{S}:$ 年上?もっと年上です。

$\mathrm{T}$ : 教え方とか、先生の性格とか、どうでしたか?

$\mathrm{S}:$ うん $[7.5 \mathrm{sec}]$ あの、日本より、PSU、あー…日本の先生より PSU の先生が、 あの、うーん、もうちょっと元気で、楽しいと思います。でも、PSU の先生たち やさしいです。@

T: @ありがとうございます。ええ、じやあ、あの、そうだな。スティーブさん の知っている人とか友達の中で、誰が一番、やさしい、とか、親切だと思います か?

$\mathrm{S}:$ うーん[2sec]みんなは親切だと思います。

$\mathrm{T}$ : ふーん、でも一番は誰ですか? 
$\mathrm{S}:$ 一番ですか?あー、うーん[5sec]

$\mathrm{T}:$ ともだちとか、家族とか。

$\mathrm{S}:$ う一ん...ただん、留学生ときに会った人。あー…コロラドから来ました、あ の、ジムさんです。あー、ジムさんはとてもやさしい、みんなと[4sec]to get along with?

$\mathrm{T}$ : 仲良くなる?

S: 仲良くなります。

$\mathrm{T}$ : じゃあ、ジムさんが、例えば、親切だなあと思ったときの思い出ってありま すか?

$\mathrm{S}:$ う一ん[16.5sec]

$\mathrm{T}$ : 誰か助けたりとか。

$\mathrm{S}:$ う一ん[10sec]@すみません、別の思い出‥ができません。

$\mathrm{T}$ : そうですか@じゃあ、いいですよ。大丈夫です。じやあ、あの、ジムさんと は同じタイミングで留学したんですか?

$\mathrm{S}:$ はい、あの、あ一、同じ寮に住んでいました。

$\mathrm{T}:$ ふーん、そうですか。ヘー、寮はどうでしたか?

S: あ一ん、まあまあでした。@あ一、寮の人たちはいい人で、あの、管理人さ んはとても‥よくて、やさしい...管理人でした。でも、あの、あ一男だけの寮、 ですから、らーん、よく污いになりました。キッチン‥トイレもいつも@污い と思いました。あの、管理人さんが…大変仕事がありました。でも・文くがんば りました。

$\mathrm{T}$ : そうですか。じやあ、あの、その管理人さんが部屋を掃除したり?

$\mathrm{S}$ ：あ一、部屋じゃない、じゃありません。あ、キッチンとトイレとシャワーと、 寮の外を掃除しました。

$\mathrm{T}:$ うーん、そうですか。

S: たくさん、たくさん、40ぐらい、40人ぐらい男の子。

$\mathrm{T}:$ わあ、それは多いですね。シェアルームでしたか?一人一人?

$\mathrm{S}$ : 一人一人です。でも 4 階で、あ一、4 階で、トイレがありました。でも[2sec] 1 階に 4 シャワーとキッチンありました…そう、部屋が一人一人ですけど、トイ レとキッチンとシャワーがシェアしました。

T: ふーん、そうなんですね。じやあシェアスペースは管理人さんが担当。自分 の部屋は自分ちゃんと掃除していましたか?

S: はい、もちろんです。@

$\mathrm{T}:$ @じやあ、大変なことがあったときに、誰に相談しましたか?

$\mathrm{S}:$ あー[1.5sec]

$\mathrm{T}:$ いつでもいいです。留学だけじゃなくて、大変なことがあるとき。

$\mathrm{S}:$ うーん[3.5sec]ときどき、母に相談します。

T: ふーん、そうですか。お母さんは、どんな対応をしますか?

$\mathrm{S}:$ う一ん、母が[2sec]いいアドバイスを[3.5sec]*あげてくれます。ときどき。

$\mathrm{T}$ : なるほど。他にいますか?友達とか。

$\mathrm{S}$ : あ一、う一ん、あ一[5sec]そんなにいません。あまり。@自分で解決します。 
T: @じゃあ、困ったことがあっても一人で解決するタイプですか?

S: うん。そうです。@

T: わたしもそうです。@あまり人に言わないかもしれない。

S: 大変ですね。@@

T: @じゃあ、最後の質問なんですけど、人生で感謝している人は誰ですか?

S: あ一[5sec]感謝?

$\mathrm{T}$ : 感謝、授業でしたじゃないですか。

S: あ、その感謝。

$\mathrm{T}$ : ええ、appreciation とか gratitude の意味です。

S: あー、[3sec]わたしの友達たちです。

$\mathrm{T}:$ ふーん、どうして、友達ですか?

$\mathrm{S}$ ：あー、らーん[2.5sec]大学に入るとき[2sec]あ一、わたしのアパートが[2sec]高 くなりました。それから[2.5sec]友達があー[6sec]友達の家に一[1.5sec]すー[1.5 $\mathrm{sec}]$ 集ませました。あ、@ 2 回です。@[3sec]

$\mathrm{T}:$ その人は?なんていう友達ですか?

$\mathrm{S}$ ：あ、あの、一番目は…アンさんと、エミリーさんの家に住んでいました。で も、その人の relationship が別れました?

$\mathrm{T}:$ あ、じゃあ、カップルだったんですか?

$\mathrm{S}$ ：そうです、でも、they broke up。それから、[1.5sec] 2 番目のジェイさんとジョ

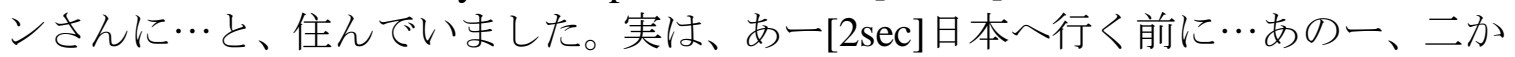
月、二か月前に、あー、アンとエミリーの家から[4.5 sec]あ、引っ越し[1.5 sec]なけ ればなりません…でした。そー、あー@[2sec]あ一、それから、私が…゙ここで日本 に行く前に、私がどこで...住むかわからなかった、からジェイとジョンが[4sec]@ むずかしい...の家に引越ししました。それから日本、に帰った後で、その家に住 みました。

$\mathrm{T}:$ あ、そうですか。じゃ、また同じ家に?

S: はい、4か月でしたㄴ.思います。

$\mathrm{T}:$ じゃあ、その人たちにあの、その人たちに対してどんな気持ちですか？

D：あーん…実は、あの、ジョンさんは、私の 1 番の友達…ですけど、うーん… たぶん...あ一[6.5 sec]一緒にいる時間が、たくさん過ぎました。あー、それから、 あの、この頃、そんなに、あー[1.5sec]遊んでいません。

$\mathrm{T}$ ：うん、じゃ、例えば、そのジョンさんのうちに引っ越して、その時に、感謝 の気持ちを伝えましたか?

D： …伝えますは?

T: あ、伝えるっていうのは convey するっていう意味です。

D: うーん[2sec]あ、ありがとうの言葉、を話します。

$\mathrm{T}$ : 例えば何か手伝ったりとかしましたか?

D: あ、そうそう。何でも[2sec]あ一、何があっても、いつも手伝いますとか、助 けます。

T: ふーん、そうですか。ありがとうございました。以上です。 


\section{T: Takizawa (Interviewer), A: Subject\#7: Alex}

$\mathrm{T}:$ えっと、アレックスさんの出身地はどこですか?

A：出身は、ポートランドです。

$\mathrm{T}:$ じゃあ、あの、高校はどこに行きましたか?

$\mathrm{A}:$ 高校は、 2 年で、えっと、 L 高校という学校でしたけど、やめて、えー、 $\mathrm{S}$ カ レッジに、えっと、高校生として、えっと、編入しました。

$\mathrm{T}$ : なるほどね。すごいですね。日本語はどのぐらい勉強してますか?

A：えーと、今までで、三年間ぐらいです。

$\mathrm{T}$ : 三年間ぐらい?すごいなー。

A：でも、ずっと、高校生、高校のときから勉強しましたけど、でも、えっと、 $\mathrm{S}$ カレッジであったんですが、でもそのプログラムのために、あーっと、日本語 の授業をとっちゃダメって言われました。なんか卒業するために間に合うために、 ほかの授業をなんか早速とらないとダメって言われました。

$\mathrm{T}:$ じゃあ、あのその時は、日本語の授業はとってなかったんですか?

A: とってなかったです。

T: ああ、そうなんですか。

A：で、休んで、O 大学に入って、それもなかったので、で、ポートランドにや っと入ったら、やっと日本語がとれるぜ一って思いました。

A：なるほど、PSUでね。ああ、そうなんですか。じゃあ、どうして日本語を勉 強し始めたんですか?

A：どうです...どうだろうねー。本当に僕には知りません。

$\mathrm{T}:$ ああ、そうなんですか?

A：ただ、なんかずっとから、えーと、日本語の発音など、なんか面白いかなー つて

$\mathrm{T}$ : 発音?

A：発音とか、なんかどうやって感情するとか。

$\mathrm{T}$ : 感情を?

A：えーっと、自分の感情をどうやって伝わるか。それがおもしろかったと思い ました。

$\mathrm{T}:$ でもどうして日本語だったんですか？

A：ふーん、なんかずっと日本のアニメが好きでした。それは、俺のきっかけで した。ああいうチャンス。

$\mathrm{T}$ : アニメね。そうですか。

A：でも今はあまり見ませんね。

T: ああ、そうですか。

A：たまに勉強のために漫画を読むことにしますけど、あ一、勉強が忙しいから、 なんかあんまりそういう余裕ないですね。

$\mathrm{T}$ : なるほどね一、じゃあ、今一生懸命勉強しているんですね。

A：ああ、まあ、そんなことないですね。

T: じゃあ、あのう、いろんな先生から、あの、勉強したと思うんですけど、好 きな先生は誰ですか? 
$\mathrm{A} ：$ 好きな先生というのは...

$\mathrm{T}$ : 日本語だけじやなくてもいいです。自分の今までの学校生活で一番好きな先 生は?

A： えっとー、ベン・ブラウンという哲学の先生でした。

T: ああ、そうですか。

A：なんか毎日輪を作って、みんな、なんか話し合いました。なんかいろいろな あの日のうーん、なんていう、文章についての話して、でもいつも輪を作って、 みんなで見ながら話し合ったんですね。

$\mathrm{T}$ : ふーん、

A：えっと、もうあとは、人数が少なかったですね。その大学は人数が少ないか ら、全体的に、えっと、具体的に、あ、基本的にいつもちっちやい、人数が少な いから。

T: ああ、そうですか。じやあ、どうしてその先生が好きだったんですか?

A：いつも、えっと、わからないことがあったら、いつも、ちょっとスラングか もしれませんけど、めりょく? 目力が強かった。いつも本当にえっと、先生がな んか自分のことを聞いてるかわかりました。

$\mathrm{T}:$ ふーん、なるほど。

A：いつでもなんか自分のオフィスに来てください。なんか、学生のためにコー ヒーでもなんか作ってあげるから。って言ってくれました。

T: なるほどね。へー、いい先生ですね。じやあ、次の質問ですが、えっと、今ま での誕生日で、一番良かった誕生日の思い出はなんですか?

A：18 歳のときですね。

T: ああ、そうですか。

A：うん。そのために、えっと、お母さんが留守番してくれました。

$\mathrm{T}:$ ぶんん。

A：そのでかい家で、なんか、俺の 18 歳のパーティを出来上がりました。

$\mathrm{T}$ : お母さん、じゃあ、そこにいなかったんですか?

A： はい。なんか楽しんできて、って言って、で、ある彼氏と、あのキャンピン グに行ってきました。

$\mathrm{T}$ : ふーん。

A：で、二日間で、僕はなんか家の担当でした。

T: ふーん、それは何か友達と...

A：集まって、うん。

T: どんなことしたんですか?

A：どんなことしたんでしょうかね称。@

T:@

A:@@@

T: あ、そうですか。へえ、じゃあ、それについて、じゃ誰がプランしたんです か?お母さん?それともアレックスさん?

A：うーん、なんか曖昧にお互いに、なんか計画を立てましたね。

$\mathrm{T}:$ ヘー。 
A：なんかお母さんは、なんか、ま、なんか私はキャンピングしに行ってきます ねー。なんか変なことするなって言われましたけど。

$\mathrm{T}:$ ふーん。

A：あ、ぜんぜーん。勉強するよーっつって。@@

T: @でもお母さん知っていたんですか?

A：そうそうそうそう。でも、あのときにコミュニケーション能力がなんか低 くて、あんまりよくなくて。

$\mathrm{T}$ : あ、お母さんとの関係?

A：あ、でも今は本当に仲いいですね。

T: あ、そう、へー、よかったですね。じゃあ、なんかプレゼントとかはあり ましたか?

A: うーん[1.5sec $]$

$\mathrm{T}$ : なんか、え一、友達とかから。

A：なんか、水たばこを吸うためのパイプをもらいました。みんなと友達の全員 がお金が集まって、すごい、えっと、高級的な、なんか、水たばこの、えっと、 機械をもらいました。

$\mathrm{T}$ : ヘー。えー、じゃあ、次なんですけど、えっとー、留学してましたけど、留学 中に誰かにお世話になりましたか?

A：そうですねー。えっと、えみちゃんという女の子がいました、いたんですが、 えっと、実はね、2 か月、えっと、親友のおばあちゃんと暮らしてたんですが、な んかいろいろあって、喧嘩したりしまして、なんか、出なさいって言われて、で、 4 日間ホームレスでした。

$\mathrm{T}:$ えー!

A：で、なんか友達がお世話になりました。なんか、ここに泊まってもいいよっ て言ってましたから。本当に本当に助かりました。まだ授業があったのに、なん かいろいろなところに行かなきやいけませんでしたね。

T: ふーん。

A：それとも、荷物はまだ、えっと、おばあちゃんのところにあったのに、なん かまだ授業に行かないとだめですよね。

T: あ、アレックスさんが?

A：そう。でもなんか、ああいう服しかなかったです。

$\mathrm{T}:$ ああいうって?

A：えっと、出された、えっと、服しかなかったから、すごいなんか臭かったっ て言われました。

T:@@@

A：@@いろんな友達に。でもしかたがなかったですね。

$\mathrm{T}$ : それは喧嘩したんですか。

A：そう。ばあちゃんは、91 歳でしたから、なんか記憶力もなんか毎日忘れたり

しますし、だからちょっと、僕は行く前、そこまで記憶力は少ないとは思わなか った。ちゃんと友達が言ってくれませんでしたから。

$\mathrm{T}:$ うーん。じやあ、二人で住んでたんですか? 
A：はい、二人で住んでました。たぶん、おばあちやんの期待は毎日なんか生活 したかった、と感じましたね。でも僕は、なんかせっかく留学に来たし、えっと、 いろんな人脈を作りたいし、友達を作りたいし、だから毎日学校から、学校が終 わって、図書館で勉強して、友達と遊んで、帰って、寝て、起きて。でも、おば あさんはそこまでわかってくれませんでした。

T: なるほど。

A：なんかなんで毎日毎日遊んだりするんですかって。

$\mathrm{T}$ : あ一そっか。それで、じやあ出てけって?

A：まあ、出てけって。なんか 2 週間で、なんか友達の家に泊まってみたらどう でしょうかって。みたいな言い方で。でも実際になんかもうなんか...

$\mathrm{T}:$ で、そのとどうしたんですか?

A： えっと一出てって、授業に行って。でもほんと。最初から、本当に出ていき なさいっていう意味とは、なんか、感じてなかった。僕の日本語は感情が伝わら なかったところでしたから。

$\mathrm{T}$ : うんうん。

A：だから、で、帰ったら、なんかもう一回おばあちやんのところに帰って、「え? なんでいるんですか」って言われました。え、本当にもうなんか、「自分といたく ないですか」って尋齐たら、「はい」って。なるほど、じやあ、「バイバイ」みた いな@@

$\mathrm{T}$ : ヘーそして、じゃあ、出て行って、そのあとにじやあ本当にホームレスに? どこで濅てたんですか?

A：まあ、友達を呼んで、なんか「ちょっと邪魔していいですか」って尋ねて、 「いいよ」つつつて。

$\mathrm{T}:$ ふーん、それで友達のうちに泊まってたんですか?

A：はい、でもシェアハウスでしたから、最初から、えっと、別の留学生のシェ アハウスでしたけど、それは初の 2 日間でした。その残りの二日間は、そのえみ という友達の家にお邪魔しました。

$\mathrm{T}$ : その、えみさんは友達だったんですか?

A: はい、だったんです。

T: ふーん、じやあ、えみさんから言ったんですか?うちにどうぞって。

A： いや、俺は本当にすごいピンチになってましたから、本当に「手伝ってちょ うだい」って言っていました。最初から、なんかあ一なんか家族から「男なんて 来ちや禁止だ」って。でも「本当に二日間だけ、二日間だけ」って頼んでました。 で、「いいよ」って。で、そこから、なんか俺らの仲がなんか、え、なんか本当に ハイレベルになったきっかけでした。そこまで、なんか一般の友達でした。なん か、大学に入って、「あ、えみー！おつす」みたいな関係でした。でもそこから仲 が良くなって、今もなんか毎日電話したりします。

T: あ、そうですか。で、結局二日しか泊まらなかったんですか？

A: はい。

T: あ、そうなんですか。じゃそのあと出て行って? 
A：はい。なんか面接と、えつと、バイトの面接と次のシェアハウスの面接もあ る予定がありましたから、「全然いいよ」って言ってくれました。

$\mathrm{T}$ : ヘー。じや、次の質問ですけど、知っている人の中で誰が一番親切だと思い ますか?

A：[2sec]友達が多すぎるからー@@たぶん、えみちやんでしょ。いつもなんか例 えば市役所に行かなきやいけないことが、えっと、いっぱいありましたね、日本 にいる間。で、なんか書類はいろいろな複雑な漢字が書いてあったり、なんか、 本当になんかどうやって言えばいいか全然知りませんでした。だから、なんか、 えみさんがなんか付き合ってくれました。なんか、一緒に行こうって。で、その あと、なんか、「なんでも質問でもありましたら、全然連絡してください」って、 言ってくれましたし、なんかいつも「元気? 日本の生活大変じやないですか」っ て。「大丈夫、大丈夫、大丈夫」って、なんかいつもなんか引き受けてくれました。

$\mathrm{T}$ : 引き受けてくれましたっていうのは?

A: なんか take care of ?

T: あ一なるほど。気にかけてくれたんですね。あ、そう、いい人ですね。

A: ええ、いい人です。

$\mathrm{T}$ : じゃあ、次のクエスチョンです。人生で大変なことがあったとき、誰に相談 しますか?

A: えー、JSL?のとき?

T: JSL? じんせい。

A：あ女、人生。@@

$\mathrm{T}$ ：@人生で大変なことがあったとき、誰に相談しますか? 経験でもいいし、例 えばでもいいし。

A：兄貴ですね。

$\mathrm{T}$ : へえ、どうして?

A： えっと、シングルマザーで育ってて、なんかお父さんもいなかったので、お 母さんいつもいつもなんか働いてますし、なんか、おに、兄貴しか相談して、乗 れませんでした。もうなんか生まれてから、仲がいいはずですので、なんか本当 になんか、俺の気持ちわかるから、兄貴が、いつもなんかあったら、まず、えっ と・・兄貴に相談にのり、相談、相談、相談乗ってもらいますね。なんか、僕は、

もう、文系みたいな人で、兄貴はもっと理系な人で、なんか、理論が欲しかった ら、いつも、なんか、えっと、兄貴に相談に行きます。

$\mathrm{T}:$ そうすると、じゃあ、お兄さんはどんなアドバイス寸るんですか?

A：や、なんか、理論的に、こうするべきですよ、と言いますね。

$\mathrm{T}$ : ああ一、なるほどね、じやあそれは助かるアドバイスですか?

A：はい。で、逆に、兄貴が相談して欲しかったら、いっも僕になんか、相談に 乗れますね。

T: あ女、いい関係ですね。それは。

A：うん。なんか、お母さんと兄貴、いつもなんか頭がぶつかりしますから、で も僕は、もう文系みたいな考え方があるので、「あ一、それは、もうちょっと他人 
の気持ちわかって、それを考えながら、なんか仲が直れるかもしれない」とよく お兄ちやんに言いますね。

$\mathrm{T}$ : ふーん、いい家族ですね、サポートしあって。

A: ああ、そうそうそう。

$\mathrm{T}$ : じやあ、最後の質問です。人生で感謝している人は誰ですか?

A：そうですねえ。滝澤先生ですねえ。いや、いや圥談。@@

T: @@圥談! ?

A：@@えーつと、一番感謝しているのは[1.5sec]う一ん、どうですかねえ...まあ、 結局お母さんじゃないですか。

$\mathrm{T}:$ ふ⿻ん。

$\mathrm{A}$ ：本当に、なんか、九ケ月風邪をひきながら、なんか僕を、なんか生んでまし たね。そう、シングルマザーで、毎日毎日自分のために動いてきました。だから、 一番感謝しているのは、お母さんでおります。

T: ああ、そうですか。それ、お母さんに言っていますか?

A：もう何回も。今は本当に仲がいい。

T: いいですねえ。じやあ、そのなんか、お母さんに感謝している気持ちをどう やって伝えていますか?

A：え、いつも僕は、言葉よりえつと、なんか行動通して、なんか、自分の気持 ちを伝わるべきだと思います。言葉は言葉です。行動はもっと深い意味があると 思います。毎日手伝ったり、なんか相談して、あげたり、なんか、もっと意味が あると思います。言葉は言葉。

T: なるほどね。言葉よりも行動が...

$\mathrm{A}$ : 大切です。

T：なるほどね。わかりました。以上です。ありがとうございました。

A: こちらこそ。

\section{T: Takizawa (Interviewer), B: Subject\#8: Brian}

$\mathrm{T}:$ えーとー、出身はどちらですか?

B: えーと...まあ、えーと、カリフォルニアに生まれたんですが、えーと ...そ一、 まあ、6 歳ごろに、えーとー、ポートランドに引つ越しました。

$\mathrm{T}$ : あ、そうですか。

B: はい、家族と。

T: あ、そうですか。じやあ、あの一、高校はポートランドですか?

B: はい、高校はポートランドです。

$\mathrm{T}:$ なんていう高校ですか?

B: えーと、A 高校です。

$\mathrm{T}:$ それはどこにあるんですか?

B: サウスウェストポートランドにあります。

$\mathrm{T}:$ ふーん、なるほど。えーと、じやあ、どのぐらい日本語を勉強していますか?

B: えーとー、まあ、今年に終わってから 3 年です。

$\mathrm{T}:$ うんん、じやあ、二年半ぐらいですね。

B: はい。 
T: えー、じやあどうして日本語を勉強し始めたんですか?

B: はい、ま一、えっと、しょう、小学校のときのごろに、えーと、私の友達は、 日本人でしたから。えーとー、すごくいいなく、いい仲になって、えーと、いつ も遊んでいて、えーと、それで、えと、友達の家族は、私に、えーと、日本の文 化とか、日本の食べ物とか、えと一、ま一、くれて、興味になりました。

$\mathrm{T}$ : ふーん、なるほどね。はい。えー、じゃあ、うーんと、そうですね。いろいろ な学校で勉強したと思うんですけど、日本とかPSU とか、高校とか、えーと一番 好きな先生は誰ですか?

B：一番好きな先生ですか? そうですよね。えーま一、心理学の、ま一、心理学 の先生のほうは、えーと[1.5sec]えーと、ジョーダン先生です。すごくおもしろく て、私の同じ将来に...して、すごく...まあ...look up ということあります。

$\mathrm{T}$ : 尊敬ですね。

B: はい、尊敬です。

$\mathrm{T}$ : ああ、そうですか。どうして、あの一、その先生を尊敬していますか?

B：えーと、ま、寸ごく明るくて、それで、えと一、ま、同じことをして、私の 将来は、セラピストになりたいんですから ...えーと、ま、えーと、ジョーダン先 生は、えとー、いつも、わたしは、いつも暇があれば、いつもオフィスに行って、 いろいろなことを教えてくれますので。

T: あーそうですか。いい先生ですね。

B: はい。

$\mathrm{T}$ : じゃ、次の質問ですけど、一番良かった誕生日の思い出はなんですか?

B：誕生日の思い出ですか...えー[2sec]と、そうですよ悋。まあ...たぶん[1.5sec]15 歳に、15 歳になる、になった誕生日だと思います。

$\mathrm{T}: 15$ 歳のときの誕生日ですか?

B: はい。

T: それはどうしてですか？

B：まあ、そのー、そのー、年に、わたしのおばあちゃんと、えーと[1.5se]おばあ ちゃんと[1.5sec]えーと、お母さんの妹は、アメリカに来ましたから。はい。家族 はたいていメキシコに住んでいますから、あまり ...えーと、会うことがあまりな いんですから、すごく、すごくいい誕生日と思いました。

T: あ、じゃあ、15 歳の時に家族がアメリカに来たんですね。

B: はい。

T: あ一そうですか。それはよかったですね。なにかプレゼントとかありました か?

B：いや、あまりなかったですね。わたしの家族はお金とかあまりないですから。

T: ふーん、そうですか。わかりました。

B: はい。

T: わかりました。じゃあ次ですけど、日本に留学していましたね？

B: はい。

$\mathrm{T}$ ：その時に、誰かにお世話になったことはありますか？

B： えーと、はい。えーとー、えっとーホストファミリーとお世話になりました。 
T: ふーん。

B：それと、ほかの留学生もいました。

$\mathrm{T}$ : 例えば、何かホストファミリーにお世話になった思い出とかありますか?

B: まあ、いろいろなことですよ㸚。えーとー ... 緒に旅行して、えーと、いろ いろなレストランとか、案内して…と、いつもこ、ま、飲むのことをよくしまし た。お父さん、ホストファミリーのお父さんと。

T: ああ、よくお酒飲んだんですか? @

B: はい@お酒です。

T: あ、そうですか。@

B: はい@

$\mathrm{T}$ : じゃあ、次の質問は、ブライアンさんが知っている人の中で、誰が一番親切 だと思いますか?

B: $[1.5 \mathrm{sec}]$ そう $[2 \mathrm{sec}] う 一 ん[2 \mathrm{sec}]$ あ、たぶん $[1.5 \mathrm{sec}]$ だ゙ん私の一番友人だと 思います。

T: ふーん。

B: はい、一緒に、ま、ここ、えと、オレゴン州に引っ越してから一緒に過ごし てから、一緒に育っていましたから。えと、私たちは、いっも一緒に遊んで、ま あ、家族はいなくになりましても。

T: じゃあ、どうして、その人のことが親切だと思いますか?

B: えーと、まあ、私はなんでも、なんでもして、友達はいつもわたしのことを おん、応援してますから。

T: ふーん、そうですか。それは、あの、お互い?

B: はい、お互い。

$\mathrm{T}$ : なるほどね。いいですね。じゃあ、次ですが、ブライアンさんが人生で、大 変なことがあったときに、誰に相談したりしますか?

B: まあ、その同じ友達に、はい。

$\mathrm{T}$ : ふーん。あ、そうですか。

B: はい。

$\mathrm{T}:$ じゃ、例えばなんかいいアドバスがありましたか?

B: ま、たいていアドバイスとかはあまり ...そう、えっとー、アドバイスとかは 関係あまりないんですが、なんか、誰かがわたしの文句を聞く...聞くを、あ、え っと、聞くのは、わたし、聞くのは、すごく、あ、えーと、すごく[1.5sec] あ、えーとー、まあ、大切だと思います。アドバイスというか...それは...そう、 アドバイス、というのはあまり探してないんです。

T: うーん。なるほど。

B: はい。

$\mathrm{T}$ : じゃあ、あの、友達は別にアドバイスをするんじゃなくて、友達は、うん、 ただ、こう、そうだねって

B: はい、そうです。

$\mathrm{T}$ : じゃあ、最後の質問ですけど、人生で感謝している人は誰ですか?

B：感謝している人は、まあ、ま、わたしの先生です。 
T: ふーんん。

B：ま、みんな、はい、えっとー、わたしは[1.5 sec]えっと、高校生のときに、わ たしは、大学に入れないそうでしたから。えとー、私の家族はお金とかあまりな いですから。えとー、先生は私のことを応援して、えとー、まー、アプリケーシ ヨンとか、いつも、えと一直して、えと一、まあ、奨学金とかもらいました。そ れから、先生に、先生にとても感謝しています。

T: ふーん、なるほどね。

B：まあ、留学したときにも、えと一、田辺という、田辺先生。えと、まあ、も う卒業、ここに卒業、まあ、ここに卒業していましたから、えとー、まあ、えと 一、田辺先生のてつ、*お手伝いもらって、もらったから、関西外大に留学できま した。

$\mathrm{T}$ : あ一、田辺先生って、PSU の?

B: はい、もう 2 年ぐらい前ですね。

T: はい、わかります。

B: はい。

T: じゃあ、田辺先生は、どんな、あの、お世話になったっていうのは、例えば どんなことをお世話になったんですか?

B: まあ、わたしは、そのときにわたしは日本語の 1 年生でしたから、私は田辺 先生と TA オフィスに先生に行って、えーと、宿題とかを㹸手伝いもらいました。

$\mathrm{T}$ : ふーん、なるほどね。

B: [whisper] 手伝ってもらいました。

T: いい先生ですね。

B: はい。

$\mathrm{T}$ : じゃ、例えば、その、自分が感謝している人に、どうやって気持ちを伝えま すか?

B: ま、わたしは、まあ、ただで...ま、ただで言って、えと、それで、わたしの していることを教え、えと、教えます。例えば、えとー、えと一、留学できてて、 その、結果をもらって、先生に伝えます、とか。

T: あ、それで、合格の結果を伝えたんですか?

B: はい。

T: あ、結果を伝えたときに感謝の気持ちも伝えたんですか?

B: はい。

$\mathrm{T}:$ なんて言ったんですか?

B：まあ、ま、いろんなこととか...ここまでに、ここまでに、えーと、なんだっ け[3.5sec]えーと、えと、えと、先生のお陰でここまでにできました。とか。

$\mathrm{T}$ : なるほどね。

B: はい。

T: あ、それは、じゃあ、先生にとってもすごく嬉しいと思います。

B: はい。

T: はい、じゃあ、ちょっとここで一度切りますね。ありがとうございました。

B: ありがとうございました。 


\section{T: Takizawa (Interviewer), K: Subject\#9: Kelly}

$\mathrm{T}:$ えーとー、ケリーさんは、出身は?

$\mathrm{K}$ : カリフォルニアです。

$\mathrm{T}:$ そうですか。じやあ、高校はどこに行きましたか？

$\mathrm{K}$ ：あ一、高校は、カリフォルニアの高校です。

$\mathrm{T}$ : ヘーそうですか。じやあ、日本語は、どのぐらい勉強しているんですか?

K: んー‥まあ、高校生一年生から今まで、日本語を勉強しているけど…

$\mathrm{T}$ : そうすると、何年間ぐらいですか?

$\mathrm{K}$ : う一ん、5 年? 6 年間くらい。でも、高校生のときにあまり…女の一、あの 日本語あまりしやべれなかったけど、ずっと、あの、カタカナとか、ひらがなと か、漢字勉強しました。

T: あ、そうなんですか。じやあ、えっと、どうして日本語を勉強しようと思っ たんですか?

$\mathrm{K}$ ：ん一、なんか、子どもの時に、あの、アニメとか漫画とかめっちや興味があ るから、日本語を勉強したいと思ったけど、なんか私の両親も、あの一、日本人 ですけど、なんか日本語しゃべない、しゃべれ、しゃべ、しゃべることができな い。

$\mathrm{T}$ : 日系人ですね。

K: はい、日系、さん、さん、3世?

$\mathrm{T}:$ ああ、そうなんですか。

K：はい。でも私のおばあちゃんは子どものときによく、よく日本語を話したけ ど、今あまり使わないので、あんまり話さないので、全部忘れちゃったんです。

$\mathrm{T}$ : あ、そうですか。おばあちやんも、じや、カリフォルニアで生まれて、カリ フォルニアで育った?

$\mathrm{K}$ : カリフォルニアで生まれましたけど、おばあちやんの両親は、あの、お父さ んは、岩手から、カリフォルニア移民しました。

$\mathrm{T}:$ ふーん、なるほどね。ありがとうございます。えーと一、じやあ、いろんな 先生から勉強したと思うんですけど、一番好きな先生は誰ですか?

K: えーーー! @@うーん[3sec]

T: @@日本語だけじゃなくてもいいです。なんの勉強の先生でもいいです。

$\mathrm{K}:$ たぶん、うーん[3sec]関西外大で勉強しているとき、ときに、日本語の先生は すごく印象的でした。

$\mathrm{T}$ : あ、そうですか。どうしてですか?

$\mathrm{K}$ ：なんか、先生は、よく、あの、時間、よく、なんだ、うーん、いつでもたす け、助けることができますから。いつでも、今、なん、いつでも、いつでも、時 間があるかららーん、あ、時間があつ...たり、なんかすごくやさしい人、だし、 う一ん、なんか先生の授業はいつも楽しかったです。

T: ふーん、なるほどねー。は、わかりました。じやあ、次の質問ですが、えっと 一、一番よかった誕生日の思い出は何ですか? 
K: えー@うーん $[1.5 \mathrm{sec}]$ 多分、21 歳の誕生日?なんか、アメリカで 21 歳になる ときにお酒とか飲めるから、なんか、レスタ、レストランとか…女の、バーとか、 バーで、飲みるから楽しかった。

$\mathrm{T}$ : そうですか。なんか子供のときの誕生日の思い出とかありますか？

K：う一ん、んまあ、たぶん、子供のとき? ...18 歳の誕生日、大丈夫ですか?

$\mathrm{T}:$ ああ、はい、どうぞどうぞ。

K：18 歳の誕生日のときに、あの、わたしは家族とわたしの卒業旅行？あの、行 っ...たときにめっちや、あ、とても楽しかったです。

$\mathrm{T}$ ：あ、そうですか。それはどうして楽しかったんですか?

$\mathrm{K}$ : あの一、あの、フロリダのディズニーワールド行ったり、ディズニーの、あ のー、ボートクルーズに乗ったり、すごく楽しかったです。

$\mathrm{T}$ ）、そうですか。へー、いい思い出ですね。

K: はい。@

T: じゃあ次ですが、留学中とか旅行中に誰かにお世話になったことはあります か?

K：すみません。もう一度お願いします。

$\mathrm{T}$ ：留学中とか旅行中に誰かにお世話になったことはありますか？

$\mathrm{K}:$ 旅行?

$\mathrm{T}$ : ううん、留学でもいいです。日本にいるときとか。

$\mathrm{K}$ : うーん...たぶん、あの、留学していたときに、あの一、私と他の留学生と関 西外大から近くの、あの小学校でボランティアしました。それが、すごく、あの、 楽しかった。なんか、あの、私は、あの子供[1.5 sec]と、あの一、ボランティアし たことないから、すごく楽しかった。初めて。

$\mathrm{T}$ ：あ、それは手伝ったんですね。

K：はい、全部英語を、あの、なんだけ[3sec]I forgot...英語をあの、教えてあげま した、子供に。

$\mathrm{T}:$ じゃあ、逆に、誰かにお世話になったことありますか? 例えばホストファミ リーとか先生とか。

K: まあ、留学していたときも、ホストファミリー、すごくやさしい人でした。 なんか、あの、いつも漢字の宿題とかあの、助けて、くれました、いつも、いつ でも。うん、おか、あ、ホストファミリーのお母さんと、ホストファミリーのお 父さん、いつでも助かっ、助かりました。

$\mathrm{T}$ : ん一、なるほどね。分かりました。知っている人の中で、誰が一番親切だと 思いますか?

$\mathrm{K}$ : 親切?あー[2.5sec]親切はなんか、やさしい人?

$\mathrm{T}$ : そうそうそう。

K: うーん...@わかりま・・たくさんいる。

$\mathrm{T}:$ じゃあ、一番じゃなくてもいいです。例えば?

$\mathrm{K}$ : うーん...難しい。でも、私の母はすごく優しい人と思います。

T: うーん、それはどうしてですか? 
K: なんか、うーん、いつも[2sec]どこでも、いつでも、一生懸命がんばります。 がんばっているから、すご、私の・ロールモデルと思います。

$\mathrm{T}:$ ふーん、なにか例はありますか?

K：なんか、私の母は、なんか寸ごく大変の生活だったから、なんか私の両親は、 離婚して、離婚しましたから、なんか、シングルマザー、なんか[3.5sec]じゅうい ちじじ、11 年間ぐらいシングルマザーの生活いきましたから、なんか、すごく、 う一ん、大変と思う。わたしとお母さんとㄱうらん、わたしは、わたしのために お母さんは、何でもいつでも何でもで、で、できると思うから。

T: なるほどね。じやあ、次です。何か人生で大変なことがあったとき、誰に相 談しますか?

K: たぶん、私の母と相談します。いつもなんかイライラ寸るのときに、なんか いつも電話しています。

$\mathrm{T}$ : どうしてお母さんに相談しますか?

K：お母さんは、ちゃんと、私の文句とかちゃんと聞きますから。

$\mathrm{T}$ : う一ん。

K：なんか友達も、ちゃんとき、きけ、聞くことができますけど。お母さんもち やんと聞くことができますけど、私はお母さんと相談したら、あの、お母さんと 相談したら、楽と思います。

$\mathrm{T}$ : なるほどね。なんでも話せる。

K：何でも話せるし、壁?壁もない。なんか、恥ずかしいことも話せる。

$\mathrm{T}$ : うーん、なるほどね。いいお母さんですね。じやあ最後のクエスチョンです が、人生で感謝している人は誰ですか?

K: うーん[2.5sec]たぶん、私の義理の母? 私は本当の娘じゃないから、なんか、 でも、あの、義理の母は私は本当の娘と思っているから、すごく…やさい人と 思う。会えてよかったです。

$\mathrm{T}$ : じゃ、例えば、その人に感謝を感じたときの思い出とかなにかありますか? $\mathrm{K}:$ うんん...なんか私は、私と父の関係はよくないから、あ、あの、なんか、よ く父のことをいつも相談している。あの、義理の母と。まあ、ときどき、あの、 文句のことも、しやべっています。話しています。

$\mathrm{T}$ : なるほどね。じやあ感謝している気持ちをどうやって伝えていますか?

K: うーん@なんか、うーん、たぶん言葉で、はな・.ささないけど、たぶん、あの、 私の…アクシン、私は時間が会ったら、帰れるときに時間があったら、私の義 理の母と妹の活動とか助けて、あの、あの、手伝ってあげます。

$\mathrm{T}:$ ふーん、あ、そうですか。へー、あ、妹さんがいるんですね。

K：今年、じゅっさ、10 歳になりました。すごく若いんだけど。

T: かわいいですね。

K: はい。

$\mathrm{T}:$ じゃあ、ちょっとここでストップしますね。

K: はい。

\section{T: Takizawa (Interviewer), D: Subject\#9: Daniel}


$\mathrm{T}$ :出身はどこですか?

D：出身はオレゴン州です。

T: の、どこですか?

$\mathrm{D}$ ：ポートランドです。

T: あ、そうなんですね。じゃあ、高校もポートランドですか?

D：あ、今、出身はポートランド、でもその前は、ジョージアに住んでいました。

T: じゃ、生まれたのは?

$\mathrm{D}$ : ミネソタです。

T: あ、そうですか。じゃあ、色々なところに行ってるんですね。

D：はい、ちょっと大変です。

T: ああ、そうですか。じゃあ、どのぐらい日本語を勉強してますか?

D：今、二年間ぐらい勉強しています。

T: どうして日本語を勉強しようと思ったんですか?

$\mathrm{D}$ ：え一、ま女専攻は歴史。特に、日本の歴史だから、えーと、日本語の作文を、 えー、読みたかったら、日本語を勉強しなけれげいけないです。

T: なるほど。それで、日本語を勉強しようと思ったんですね。

D：はい、そうです。

T: なるほど。じやあ、あの一、いろいろな学校とか大学で、勉強したと思うんで すけど、一番好きな先生は誰ですか?

D：@えー、日本語の先生ですか?

T: あ、日本語の先生だけじやなくていいです。

D: 高校と中学?

$\mathrm{T}$ : そうそうそう、いろいろな。

D：えー、多分わたしのサードグレードの先生です。

T: あ、そうですか。それは、どうしてですか?

D：え、まあ、その先生は毎朝、ジムの授業、一緒にはしました。

T: はします?

D：うん、その、学校の外で、はしました。

T: 走りましたか?

D：ええ、そう、走りました。運動のためです。すみません。それで、その先生が、 ま一、長い時に先生でした。よく、わかりました。もう、優しかっていよく読み ました。

T: じゃあ、先生が優しかったって言いましたけど、どんなことが優しかったです か?

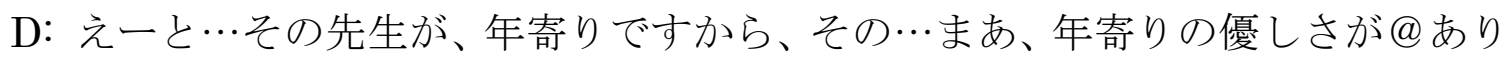
ました。

T: あ、そうですか。

D：その先生は 3 人の息子がいましたから、もう、子供の経験があって、えっと、 超…えーと、子供に優しかったです。

T: ふーん、なるほじ。わかりました。じゃあ、次の質問ですけど、えーと、一番 よかった誕生日の思い出はなんですか? 
D：えー‥っと、まあ[1.5sec]誕生日のこと、あまり覚えられません。

T: あ、そうですか。例えば、子供の時の思い出とかありますか?

D: ....や一…あまりありません。

T: 最近はありますか?

D：うーん、最近は北海道に行った時？

T: あ、そうですか。へー…

D：それは冬休みでした。冬休みで、4 日ぐらいで北海道に行きました。えー、で も札幌しか行っていません。

T: あ、そうなんですか。

D：で、札幌は、それは、冬だから、雪がいっぱいだった。雪が僕の背のたかい、 僕の背より高かったです。びっくりしました。

$\mathrm{T}$ ：すごいですね！え、じゃあ、その、北海道は一人で行ったんですか?

D：ううん、えっと、友達と行きました。

T: あ一、いいですね。じゃ、なにか誕生日のために友達が何かしましたか?

$\mathrm{D}$ ：誕生日？

T：はい、誕生日だったから、何かお祝とかしましたか?

D：あっと多分飲みました。@バーで飲みました。

T：あ、飲みましたか。そうですか。プレゼントとかは?

D：あ、えーっと一、その、安いの日本のお菓子でした。高いものじやなかったで す。

T: あ、そうですか。じんなものでしたか？

D：え一@と、その、ビックリマンチョコのこと、知っていますか?

T:はい、わかります、わかります。

D：そのシールが入っている...

T: はいはい。

D：ま、多分 5 枚を買ってもらいました。

T: あ、そうですか。@安いプレゼントですね。

D：@@えーと、好きなようになりました。友達とシールを収集してました。

T: そうですか。おもしろいですね。留学していましたけども、留学中に誰かにお 世話になったことはありますか?

D：えーっと、誰かな。ああ、えーっと、この 文のこと、えーと、手伝ってもらいました。

T: ああ、そうなんですか。

D：えーと、ま、PSU の論文は、3 年先生の末から始まるから、でも留学した。 で、あまり正しくに始められなかった。それで、ロバート先生に、留学している のに、論文を始めてもいいと思うって、聞いて、ロバートが、その帰る前にで、 日本でその先生と相談して、よく日本の資料を教えてもらって、と昔の日本の書 き方を、教えて、教えました、教えてもらった。

T：あ、そうなんですか。へー。 
D：た、例えば、古いの、ま、えー、30 年代の、ぐらいのか、書き方は、いろい ろな中国の漢字を使う。今、違う漢字を使っていますけど、それが、わかりませ んでしたから、その先生がえーと、教えてくれた。

T: じゃあ、その先生と論文を書くんですね。

D：はい、そうです。

T: いいですね。じやあ、次の質問ですけじ、知っている人の中で、誰が一番優し いと思いますか?

D：多分、その人は私のおじいさんだと思います。

T: あ、そうですか。

D：えーと、まあ、今、私の大学の、価值に、あ、大学の值段をもらっています。

T: そうなんですか。全部ですか?

D：いえ、全部じゃないですけど、大変な価值があります。

T: あ、そうですね。そのおじいさんは、どこにいらっしゃるんですか?

D：今、ニューメキシコのサンタフェにいます。

T：あ、そうなんですか。じゃあ、人生で、何か大変なことがあったとき、誰に相 談しますか?

D：えー、まあ、今、彼女と住んでいますから、だいたい彼女に相談できます。

T: あ、そうですか。彼女からはいいアドバイスありますか?

D：ええ、いいアドバイス。

T: どんなアドバイスがありましたか?

D：ま、多分、ぼくは、問題を彼女に言って、彼女が聞いて、えっと、まあまあ、 大丈夫って。それは全部頭の中にあるって。それは、アドバイスじゃなくて、け じ、全部、パースペクティブを教えます、彼女が。

T：ああ、そうですか。ふーん、じゃあ、なんでも結構オープンに話すんですか？

D：ええ。

T: じやあ、彼女とは遠距離恋愛、だったんですね。

$\mathrm{D}$ ：はい、一年間。

$\mathrm{T}$ ：大変でしたね。

D：うん、大変でした。よく、スカイプをしました。

T：あ、そうですか。それでは次の質問ですが、人生で感謝している人は誰ですか? ごうしてですか?

D：えー...まあ、いろいろな人がいます。ま、特に両親に感謝の感じがあります。 えっと、もちろん、両親が子供の時から、えーと、そだ...育てたでしょ。それに、 わたしの問題に聞いて、えーと ...うん、え、うん、よく...せいじ、あ、*もらい? もらいました?*あげました?

T: せいじ?

D：せいじ、*くれました？

T: せいじは何ですか?

D：守ると、育てるの...女、せわ！世話しました！世話を*くれて、えーと、まあ、 いい人と思います。

T: なるほじ、じゃあ、ほかにいますか、感謝している人。 
D：えーと、ちょっと考えています $[6.5 \mathrm{sec}]$ 多分、珍しい感謝けど、高校生の時に、 この世界の歴史の授業をとって、この先生があまりぜんぜん教えてない。あ、全 部の授業で、えっと、先生がみんなに教科書を読むだけ、授業でした。それで、 先生がずっと、いつも携帯を使っていました。それで、あまり…まあ、歴史がよ く好きですから、世界中の歴史がよく楽しみしていましたけど、その…先生が、 えーと、ちょっと、わるく...その先生がその授業を悪く…させた?から、あまり、 あまり、えー、なんだっけ…がっかりしました。でも、来年、ほかの、あー、ア メリカ歴史の授業をとって、ほかの先生が、もっといつも元気して、よく頭がよ くて、いつも授業と、えーと、インターアクトして、ま、それで、ま、その先生 とよく仲が良かった。

T: それは、ダニエルさんが?

D：はい、それで、ま、ときどき昼ご飯の時に、ほかの学生と、その授業の教室に 先生と一緒に食べて、話して、えーと、ま、いろいろなことを‥教えた。それで、 僕は、先生になりたいことを目覚めました。その先生のためだから、その授業が そんなに楽しくなったから、その先生が僕に目覚めさせた。

T: う一ん、それ、さっきの先生と二人いるんですが、どっちの先生に感謝してい るんですか?

D：まあ、両方。@ま、特にアメリカの歴史の先生。

T: あ、そうですか。じゃあ、インタビューはここまでです。ありがとうございま した。

D：ありがとうございました。 